\title{
Surgical treatment of hyperparathyroidism
}





\title{
Surgical treatment of hyperparathyroidism
}

\author{
WITH AN ANALYSIS OF 267 CASES
}

\section{Proefschrift}

ter verkrijging van de graad van doctor in de geneeskunde aan de Medische Faculteit te Rotterdam, op gezag van de Decaan Prof. D. C. den Haan, hoogleraar in de Faculteit der Geneeskunde, tegen de bedenkingen van de Faculteit der Geneeskunde te verdedigen op woensdag 16 juni 1971 te 16.00 uur precies, door

\section{Hajo Albert Bruining}

geboren te Eindhoven in 1943 
PROMOTOR: PROF, DR. H, MULLER CO-PROMOTOR: PROF. DR. J. C. BIRKENḦ̈GER 
To Monica and Hajo 



\section{Contents}

Introduction . . . . . . . . . . . . . . . . . . 1

Chapter I Historical review. . . . . . . . . . . . . . 2

Chapter II Anatomy and histology of the parathyroid glands . . 6

Chapter III Some remarks on the physiology of the parathyroid hormone and calcitonin. . . . . . . . . . . . . . 14

Chapter IV Histology of the parathyroid tumors . . . . . . . . 17

Chapter V Pathogenesis of primary hyperparathyroidism . . . . 23

Chapter VI Suspicion and diagnosis of hyperparathyroidism . . . 33

Chapter VII Incidence of primary hyperparathyroidism. . . . . . 39

Chapter VIII The surgical technique . . . . . . . . . . . . 42

Chapter IX Analysis of the findings in 267 patients. . . . . . . 49

Chapter X Post-operative course. . . . . . . . . . . 64

Chapter XI The prognosis of primary hyperparathyroidism. . . . 68

Chapter XII Summary and conclusions. . . . . . . . . . . . . 76

Samenvatting en conclusies . . . . . . . . . . . . 81

Literature . . . . . . . . . . . . . . . . 87

Acknowledgements . . . . . . . . . . . . 101 



\section{Introduction}

It is generally accepted that for autonomous hyperparathyroidism, whether primary or tertiary, surgery is still the only suitable method of treatment available. Analysis of a series of cases treated in this way over the past twenty years has shown that there are certain problems associated with the treatment of this disease that have not yet been solved.

Even experienced surgeons may have difficulty in finding the parathyroid glands when the localization or number is abnormal. The histological differentiation between nodular hyperplastic, and adenomatous parathyroid tissue may be extremely difficult, sometimes even impossible. It is just this difference that might determine the amount of resection and the postoperative course. Furthermore, in some cases it is exceedingly difficult for the surgeon to judge whether a parathyroid is of normal size and has a normal appearance. Lastly, the etiology of primary hyperparathyroidism is still unknown.

In the present work the findings in 267 patients treated surgically between 1950 and 1970 are discussed and evaluated in relation to the data in the literature. Special attention is paid to the etiology of the disease, the histological picture, and the surgical technique. The symptomatology, diagnosis, and biochemical changes will only be mentioned briefly, since the problems associated with them are so numerous that they deserve separate treatment. A thesis on these subjects is in preparation in Leiden.

Because the prognosis of associated disease, especially the renal, is the more favourable the earlier the diagnosis is made, some principles are given to promote earlier consideration of the diagnosis hyperparathyroidism in cases with few symptoms.

The data of 267 patients who underwent an operation between 1950 and 1970 under the probability diagnosis hyperparathyroidism are discussed. These patients were treated in the Leiden University Hospital, the Leiden Diaconess Hospital, or the Rotterdam University Hospital. In 255 of these cases the diagnosis was confirmed at surgery and histologically. 


\section{Chapter I - Historical review}

In 1871 von Recklinghausen described certain pathological changes in bone which he termed fibrocytsche Osteitis mit multiplen Osteosarcomen. He did not, however, distinguish between the local and systemic forms of this disease. In 1910 he reported on the simultaneous occurrence of nephrocalcinosis, but without having seen the relationship between the renal anomalies and the bone disease.

The human parathyroid glands were first found by Sandström in 1880 . Their function was only partially understood by Vassale and Generali (1896), although they ascribed the tetany seen after thyroidectomy in part to the unintentional removal of the parathyroid glands. Erdheim (1906) demonstrated that the tetany was the result of the parathyroidectomy and had nothing to do with the thyroidectomy, as had originally been thought. $\mathrm{He}$ also described changes in the teeth of parathyroidectomized rats, and inferred a relationship between parathyroid gland function and bone formation. Halstead (1907) attempted unsuccessfully to correct the hypoparathyroidism seen after thyroid gland operations by heterologous parathyroid gland transplantations.

An important contribution to the understanding of the biochemical changes accompanying parathyroidectomy and the subsequent tetany was made in 1909 by MacCallum and Voegtlin, who showed that in dogs the calcium level in the blood dropped after parathyroidectomy and that the clinical picture improved after the addition of extra calcium to the diet.

Meanwhile, Askanazy $(1904,1906)$ suggested with some hesitation that there might be a relationship between the occurrence of parathyroid gland tumors and decalcification of the bone, but in this period the pathogenetic relationship was not recognized. In 1915 Schlagenhaufer and Maresch recommended parathyroidectomy for the treatment of osteitis fibrosa. Nothing at all was known about the difference between primary and secondary hyperparathyroidism, i.e. the difference between autonomous hyperfunctioning and compensatory hyperplasia of the parathyroid glands. 
(In the former there is a hyperfunction of the parathyroid glands causing hypercalcemia and in the latter the compensatory hyperplasia occurs as a reaction to chronic hypocalcemia.)

It was thought that enlargement of one or more parathyroid glands was evidence of inadequate functioning of these glands. It was also assumed that there was an additional influence of the thyroid gland on the calcium metabolism, because of the greatly feared tetany after thyroidectomy, Despite Erdheim's publications it was not realized that this tetany was caused by parathyroidectomy. This inadequate understanding of the function of the parathyroid glands formed a serious impediment for parathyroid surgery. We may cite as characteristic of the 'European' conception of and approach to the clinical picture, the treatment of the patient with osteitis fibrosa by Mandl (1925), who approached the problem according to the old ideas concerning the histological picture, i.e. via the relationship between the bone anomalies and the presence of neoplastic parathyroid glands with inadequate function.

The patient (Albert J.) was a 38 year old conductor who complained of fatigue and of pain in the bones. In 1924 osteitis fibrosa was diagnosed radiographically, and he was treated with thyroid and parathyroid preparations orally to supplement an assumed deficiency. His condition nevertheless continued to deteriorate, and three months later he developed a spontaneous fracture. He was also found to have a hypercalciuria of such severity that the calcium precipitated on the sides of the urinal. In July of 1925 an attempt was made to obtain improvement in his condition by means of a homologous transplantation of four parathyroid glands. This too failed to provide a cure. As a last resort, in 1925, ten years after Schlagenhaufer's proposal, Mandl performed the first parathyroidectomy. At exploration it did not take long to find a greatly enlarged parathyroid gland on the lower left side between the thyroid gland and the trachea. The tumor, which adhered to the recurrent laryngeal nerve, was removed. The other glands had a normal appearance. Six days after the operation, the diminishment of the hypercalciuria could be observed with the naked eye, and by the fourth post-operative month the bone anomalies were appreciably improved. Subjectively, too, there was an unmistakable recovery. In 1926 Mandl wrote a treatise in which he drew the conclusion that the success of the parathyroidectomy was probably based on the fact that the tumor indicated a hyperfunction of the gland. Unfortunately, six years later the patient developed a recurrence of the hyperparathyroidism, which seemed to offer support to those who had been critical of Mandl's view from the first.

Mandl's act of desperation, which led to his patient's recovery, forms a 
sharp contrast with the more biochemical approach to the clinical picture applied in the United States. After MacCallum and Voegtlin's discovery, the experimentation with hormone extracted from bovine parathyroid glands constituted a great advance. The best known are the experiments with extract prepared by Collip (1925), who showed that after excision of the parathyroid glands in dogs normocalcemia could be maintained by means of injections of parathyroid extract (PTE). Overdosage of PTE led to hypercalcemia. He also gave the first description of a hypercalcemic crisis induced by overdosage of parathyroid hormone. Greenwald and Gross (1926) found that after PTE injections hypercalciuria and hyperphosphaturia developed to such a degree that it could only be due to bone destruction. Albright et al. (1929a,b) performed very exact balance studies on calcium and phosphate metabolism, and demonstrated that the first measurable reaction to PTE injections was an elevated phosphate excretion in the urine, from which they concluded that this reaction was a primary one. All further changes - such as hypophosphatemia, hypercalcemia, and hypercalcuria - were considered secondary to the elevated phosphate excretion.

In the later widely known patient, Captain Charles Martell, who suffered from an extensive osteitis fibrosa with pathological fractures and urolithiasis, Hannon et al. (1930) found hypercalcemia, hypophosphatemia, and hypercalcuria. These findings led them to the correct conclusion that here there was a parallel between these biochemical changes and those found in experimental overdosage with parathyroid extract. They too nevertheless treated their patient initially with with PTE, which as could be expected resulted in increased complaints. Bauer et al. (1930), of the Massachusetts General Hospital in Boston, also examined this patient and confirmed the diagnosis. In addition to parathyroidectomy, they advised treatment with a phosphate-rich diet. Despite two negative explorations, they remained convinced of the correctness of their diagnosis. Due to the resoluteness of the patient and the conviction of his physicians, the tumor was finally found at the seventh exploration, lying in the anterior mediastinum next to the left innominate vein (Churchill \& Cope 1934).

When the physiological function of the parathyroid glands became known, interest in the histological picture of the tumors increased. Although several forms had been described, such as adenoma and hyperplasia (Guy 1922), the findings continued to be highly confusing. Castleman and Mallory (1935) gave clearly defined criteria for the histological diagnosis of enlarged parathyroid glands. They distinguished adenoma, primary waterclear cell hyperplasia, and the secondary hyperplasia due to a period of hypocalcemia. An important communication was the description of the 
primary chief cell hyperplasia by Cope et al. in 1958. It was Cope in particular who was involved in parathyroid surgery from its beginning and who, in collaboration with the pathologist Castleman, initiated the development of a sound surgical treatment for this complicated disease.

In Europe, Hellstrom has also done a great deal of this work in Sweden. His relatively somber view of the ultimate result of the operation, based on the fact that despite successful surgery many of his patients finally died of renal insufficiency, influenced general opinion in the period between 1945 and 1960. In England, Dent contributed valuable methods for the diagnosis, and Davies obtained excellent surgical results. Together, they have been responsible for the first reliable insight into the etiology of tertiary hyperparathyroidism. 


\section{Chapter II - Anatomy and histology of the parathyroid glands}

\section{§ 1. EMBR YOLOGY}

In mammals the parathyroids are derivates of the 3rd and 4th pharyngeal pouches (Boyd 1950, Schrier \& Hamilton 1952, Dossel 1958).

The lower parathyroid glands develop from the dorsal part of the entoderm of the 3rd pharyngeal pouches, the remaining part differentiating to become the thymus. During its descent, this pouch forms the ductus pharyngobranchialis III, which later ruptures. The resulting tissue remants may develop into accessory thymic or parathyroid tissue. In this way, more than the normal number of parathyroid glands may develop. During the relative descent, the parathyroid tissue comes to lie apart from the thymic tissue. This separation is sometimes retarded, and in that case the lower parathyroids may come to lie not only in the thymus but also, in relation to the development of the heart, even lower (Hamilton et al. 1962).

The upper parathyroid glands develop from the dorsal part of the entoderm of the 4th pharyngeal pouches. The ventral part attaches itself laterally to the thyroid gland which develops from the entoderm of the floor of the pharynx (Boyd 1950, Hamilton et al. 1962). This has two consequences:

a. Due to this fusion the upper parathyroids undergo almost no descent, as a result of which they lie more cranially in the adult than those originating from the 3rd pharyngeal pouch.

b. The contact of the upper parathyroids with the thyroid is closer than that of the lower ones. This results in less variation in the position of the upper parathyroids than is seen in the lower ones.

\section{Numerical variations}

Man normally has four parathyroid glands. Developmental anomalies can, however, give rise to a larger or smaller number (Yonis et al. 1962). The 
inability to demonstrate more than three glands does not mean that four are not present (Heinbach 1933, Pyrteck \& Painter 1964). For 428 autopsies, Gilmour (1938) found that in $0.2 \%$ of the cases only two glands could be located and in $6.1 \%$ three glands. He ascribed this mainly to having missed the glands. In addition, fusion of two glands or agenesis may be responsible for the presence of less than four glands (Black 1963). In $87 \%$ of his cases Gilmour found four parathyroid glands. A higher number of glands can cause failure in parathyroidectomy. In $6 \%$ of his series Gilmour found five and in $0.5 \%$ six parathyroid glands. Larger numbers, up to twelve (Erdheim 1904), have been reported.

Our material confirmed these findings. In the 267 explorations, 939 glands were found, or an average of 3.5 per patient (see Table 1 ).

Table $I$. Numbers of glands found in a series of 267 explorations

\begin{tabular}{|c|c|c|c|c|c|c|c|c|}
\hline \multicolumn{3}{|c|}{0 glands in } & \multicolumn{2}{|c|}{3 patients } & $(1.1 \%)$ & \multicolumn{3}{|c|}{0 glands } \\
\hline 1 & ", & , & 12 &, & $(4.5 \%)$ & $=$ & 12 & $"$ \\
\hline 2 & " & , & 20 & , & $(7.5 \%)$ & $=$ & 40 & $"$ \\
\hline 3 & " & , & 52 & $"$ & $(19.4 \%)$ & $=$ & 156 & $"$ \\
\hline 4 & , & " & 171 & $"$ & $(64.0 \%)$ & $=$ & 684 &, \\
\hline 5 & " & , & 7 & , & $(2.6 \%)$ & $=$ & 35 & ", \\
\hline 6 & ", & " & 2 & , & $(0.8 \%)$ & $=$ & 12 & " \\
\hline & & & \multicolumn{2}{|c|}{267 patients } & & & \multicolumn{2}{|c|}{939 glands } \\
\hline
\end{tabular}

The following remarks must be made in this connexion:

a. In some patients one or more glands had been removed elsewhere in previous explorations. When we were aware of this, the glands were counted as found.

$b$. In 15 patients a thyroidectomy had been performed before the parathyroid exploration and some parathyroids might have been inadvertently removed. In these 15 patients, 18 glands could not be located.

c. In the earliest patients no systematic search was made for the other normal - glands after an 'adenoma' had been found.

d. In 13 patients three glands were found on one side.

A normal parathyroid gland weighs 30 to $35 \mathrm{mg}$. The lower pair is slightly heavier than the upper. The average weight is slightly higher in women than in men (Gilmour \& Martin 1937). The dimensions of a gland are 3-6 $\times 2-4 \times$ 
$0.5-2 \mathrm{~mm}$, the length being the most variable. In adults the color of the glands is yellowish-brown.

\section{§2. THE POSITION OF THE GLANDS}

To locate the parathyroid glands during the operation, familiarity with their anatomical relation to the surrounding structures is of great importance because of the likelihood that the glands will be concealed in or behind fatty lobuli or in the connective tissue behind the thyroid gland.

\section{The upper parathyroid glands}

From the findings in Gilmour's series of 428 autopsies, the following distribution can be calculated:

Seen in the sagittal plane, the upper parathyroids lie in $92 \%$ of the cases on the dorsal surface of the thyroid gland,

$6 \%$ of the cases between the thyroid gland and the esophagus, $1.5 \%$ of the cases behind the pharynx or esophagus, and in

$0.5 \%$ of the cases between the thyroid gland and the carotid sheath or in the carotid sheath.

Only once was a gland found on the anterior surface of the thyroid, but this may occur more frequently (Millzner 1927). The incidence of intrathyroidally located parathyroid glands is not sufficiently known. The glands often lie in a sulcus of the thyroid, but seldom really intrathyroidally, i.e. entirely surrounded by thyroid gland cells (Gilmour 1938, Pyrteck \& Painter 1964).

The upper parathyroid glands usually lie on the dorsal surface of the thyroid gland. If the latter is visualized as vertically divided into three parts, they are found:

on the upper margin of the middle third in on the upper third in on the middle third in more dorsally, toward the esophagus in behind the esophagus in
$73.7 \%$

$9.4 \%$

$7.2 \%$

$5.4 \%$

$1.1 \%$

From the foregoing, it may be concluded that the upper parathyroids are usually found in close contact with the dorsal side of the thyroid, at the level of the cricoid cartilage. The more caudally they lie, the more dorsal their location. In extreme cases, especially with large tumors, they may 
migrate toward the posterior mediastinum. The anatomical position of the upper parathyroid glands with respect to the inferior thyroid artery is less constant than that with respect to the recurrent laryngeal nerve, because the latter has a more constant position. The upper parathyroids lie dorsal to the artery and the nerve (Pyrteck \& Painter 1964, Hunt et al. 1968).

\section{The lower parathyroid glands}

In $95 \%$ of the cases, the lower parathyroids lie within an area covering $2 \mathrm{~cm}$, cranially, caudally, or laterally, from the lower pole of the lateral lobe of the thyroid gland. The more caudal the location, the stronger the tendency to an intrathymic localization. In $9.1 \%$ of the cases the lower parathyroids lie between the trachea and the thyroid or on the trachea. The lower parathyroids lie ventrally with respect to the inferior thyroid artery and the recurrent laryngeal nerve (Gilmour 1938, Pyrteck \& Painter 1964).

In our material, of the 458 normal parathyroids 361 lay within and 97 outside this region ( $78.8 \%$ and $21.2 \%$, respectively). Of the 481 pathological glands, 343 had a normal location and 138 an abnormal $(71.3 \%$ and $28.7 \%$, respectively). Abnormal localization in tumors is ascribed in part to pressure from the surrounding tissue (swallowing), gravity, and suction due to the lower pressure in the thorax at inspiration (Cope 1966, Pyrah et al. 1966).

There is no relationship between the position and the weight of the tumor or between the localization and the predominance of bone or kidney anomalies (Lloyd 1968). But there seems to be a relationship between the size of the tumor and the plasma [Ca]. However, in a few patients with high plasma [Ca], small tumors were found.

The localization of normally situated parathyroid glands generally offers no difficulties if one takes the time for it. If they are not found, however, the possibility of an abnormal position must be considered. Abnormal localizations are notorious, 'the surgeon's riddle' (Chiu-Ang Wang 1970). In principle, parathyroid gland tumors can be found in a region stretching from the base of the tongue to the diaphragm and from the clavicle to the vertebral column.

The upper parathyroid glands, as already mentioned, are found in abnormal localizations more dorsally and/or caudally than usually. They must therefore be sought in the neck as well as near the trachea, between the trachea and the esophagus, para-esophageally, and between the esophagus and the spinal column. More caudally, they are to be found in the posterior mediastinum (seldom in the anterior mediastinum) (Cope 1960, 1966). Our 
impression is that with large tumors of the upper parathyroids a more caudal position occurs more frequently than with smaller tumors.

The lower parathyroid glands show no correlation between the size of the tumor and a more caudal position. We have obtained the impression that deep sinking of these tumors is rare, because with a mediastinal localization they usually lie firmly anchored in the thymus. Abnormal localizations are almost entirely confined to the anterior mediastinum. A mediastinal localization, whether of the upper or the lower parathyroids, is reported to occur in 0.5 to $21 \%$ of the patients (Norris 1947, Hellström \& Ivemark 1962, Black 1963, Pyrah et al. 1966). This wide variation is probably due mainly to the fact that with a normal position of the head the tumor can lie retrosternally, whereas at hyperextension of the neck (as may occur during the operation) it is found in the neck. Tumors situated caudal to the aortic arch are rare.

The mediastinally situated tumors of the lower parathyroids are often located in the thymus and in the thymic pedicle (Black 1963, Muller et al. 1966). In Cope's series of 400 patients, 26 of the 84 mediastinally located tumors lay in the thymus (Nathaniëls et al. 1970).

\section{§3. VASCULARIZATION AND INNERVATION}

The arterial vascularization of the upper parathyroid glands is effected mainly by the inferior thyroid artery, which in $45 \%$ of the cases has a shunt with the superior thyroid artery (Halsted \& Evans 1907, Mauro 1950). The upper parathyroids are supplied exclusively by the superior thyroid artery in $13 \%$ of the cases, the more frequently the higher the gland lies on the upper pole of the thyroid. In $25 \%$ they are supplied via an anastomosis between the superior and inferior thyroid arteries, particularly when the localization is juxta-cricoidal. In the remaining cases they are supplied by a terminal branch of the inferior thyroid artery.

The lower parathyroids are almost always vascularized by a terminal branch of the inferior thyroid artery (Mauro 1950). The veins and lymphatic vessels enter the hilus together with the arteries, but the vessels may also penetrate the capsule and anastomose with the thyroid vessels (Balashev \& Ignashkina 1964).

Abnormally localized glands, e.g. on the pericardium, are sometimes supplied not by the inferior thyroid artery but rather from the immediate surroundings (Black 1952, Maurer et al. 1965). It is conceivable that this concerns a parathyroid that had migrated in an early embryonic stage. 
Some surgeons attempt to locate an elusive gland by following the (dilatated) thyroid artery (State 1964, Hellner 1965, Pyrah et al. 1966, Goodman et al. 1969). In view of the variations in the vascularization, it must be kept in mind that this method can only be successful in some proportion of the cases.

In our series of 267 patients we found the following arterial anomalies. The inferior thyroid artery was absent on the left in 15 and on the right in 4 patients. In 2 cases there was a direct branch from the common carotid artery to the lower parathyroids.

A bloodvessel serving as a guide to the tumor was mentioned in the surgical report 37 times in our material; its value for locating the tumor was difficult to determine. In 5 of these cases the tumor was found by dissecting along the course of the artery. The following case may serve as an example:

During exploration in a 19 year old male, biopsy samples were taken from three normal parathyroid glands. the lower left gland was not found, and the operation was terminated. Post-operatively, hypercalcemia persisted. At re-exploration six weeks later, it was noticed that the left inferior thyroid artery was strongly displaced downward, which made a retrosternal localization of a tumor seem possible. After sternotomy, a tumor which later proved to weigh $1500 \mathrm{mg}$ was found just above the aorta, vascularized by a branch of the lowered inferior thyroid artery.

The innervation of the parathyroids occurs from a perivascular plexus with two types of fibers:

a. Large myelinized fibers running superficially in the tunica adventitia of the artery. This may concern a sensory type of fiber.

$b$. Small unmyelinized fibers running deeper in the tunica media. These are orthosympathetic fibers without a distinct terminal structure and probably vasomotoric. However, they sometimes terminate in a knoblike swelling on the cell membrane of the chief cell, which suggests an influence on secretion (Raybuck 1952). Objections have been raised by Zawistowzky (1965) to this finding.

\section{§ 4. HISTOLOGY OF THE PARATHYROID GIANDS}

The parathyroid glands are surrounded by a fragile capsule formed of collagenic, reticular, and elastic fibers. Vascularization occurs mainly from the hilus, from which the vessels radiate. The veins are large. In the perivascular connective tissue mast cells are present at all ages. Fatty tissue occurs increasingly with age up to the 50th year, the fat cells lying in the 
perivascular tissue as well as solitarily or in groups distributed in the parenchyme. With increasing age the parathyroids undergo a certain degree of trabecularization, and septa develop as a result of the increasing amount of collagenous connective tissue.

The parenchyme is composed of three main epithelial components with their transitional forms:

a. Chief cells: Usually polygonal cells measuring 6 to $10 \mu$. The cytoplasm is slightly acidophilic and contains fine granules. The nucleus is dark. A distinction is made between light and dark chief cells according to their stainability with hematoxilin and eosine.

b. Water-clear cells: These round cells are twice as large as the chief cells. The nucleus has approximately the same appearance as that of the chief cell. The cytoplasm is clear, due either to total vacuolization (Castleman 1952, Engfield et al. 1959, Holzman \& Lange 1963) or to artefaction (Gilmour 1939, Stoeckel \& Porte 1966). As transitional type between the chief cell and the water-clear cell, the transitional water-clear cell, is mentioned.

c. Oxyphil cell: Also called the acidophil cell. The size of these cells varies. The nucleus is hyperchromatic, the cytoplasm contains oxyphilic granules and vacuoles. Here again, a distinction is made between light and dark cells.

So far, it has not been possible to determine the relative importance and function of these various types of cell. There is no concensus concerning the amount of PTH secretion by the various types of cell. There are indications that transition from one type into another is possible (Raisz 1963, Hotta 1965, Roth \& Raisz 1966, Weymouth \& Sheridan 1966, Christie 1967, Jowsey \& Raisz 1968).

The architecture of the parenchyme is highly dependent on age and the activity of the gland. The same holds for the cellular composition of the population of the parenchyme (Gilmour 1937/1939, Castleman 1952, Eder 1961 a,b, Christie 1967).

In healthy adults, the microscopical picture varies widely within a single gland. The chief cells may form compact nodular groups separated by septa, coarse trabeculae, lobuli, and large, sometimes ramified, acini. Nodules of oxyphil cells occur in the normal gland, but these cells are also found lying disseminated in the parenchyme. Solitary fat cells and interstitial accumulations of fat are present. An equally constant finding is microscopically visible cysts. Encountered less often in normal parathyroids are 
alveoli of cylindrical epithelium, pseudo-alveoli, and vesicles filled with pseudo-colloid (Gilmour 1939). In such cases there is a considerable chance that investigation of frozen sections of biopsy material will lead to the erroneous diagnosis thyroid tissue, as occurred in one of our patients. 


\section{Chapter III - Some remarks on the physiology of the parathyroid hormone and calcitonin}

Parathyroid hormone influences the calcium metabolism of the bone, phosphate and calcium clearance in the kidneys, and calcium resorption in the gut. The calcium homeostasis in the blood is maintained primarily by the feedback effect of the plasma [Ca] on the PTH secretion. There is no similar mechanism for the regulation of the phosphate homeostasis, since PTH secretion is not directly influenced by the plasma $\left[\mathrm{PO}_{4}\right]$ (Potts 1968, Roth et al. 1968). The application of radioimmunoassay techniques has made it possible to measure plasma [PTH] (Berson et al. 1963, Berson \& Yalow 1967, Lequin 1969, Arnaud et al. 1970). Unfortunately, this determination is still extremely difficult to perform and cannot yet be considered consistently accurate, although it supplied the ultimate proof that PTH secretion is activated only by hypocalcemia. The role played by hypomagnesemia is not yet entirely clear. There seems to be a linear inverse relationship between plasma [Ca] and plasma [PTH]. The half-life of the hormone in vivo is about 20 minutes. At a normal rate of secretion, the parathyroid glands must renew their PTH content completely 3 to 15 times per hour by de novo synthesis (Potts et al. 1968).

PTH has a direct effect on bone, resulting in the release of calcium and phosphate ions into the blood (Thompson \& Pugsley 1932, Collip et al. 1934, Barnicot 1948). The biochemical background of this phenomenon is not yet completely understood (Gaillard 1968, Hekkelman 1968, Nichols 1970).

In the kidney, PTH reduces the tubular resorption of phosphate. This effect occurs very rapidly after the administration of PTH, in contrast to the effect of PTH on the bone and the subsequent rise of the plasma [Ca] (Greenwald \& Gross 1926, Albright et al. 1929a,b, Chambers et al. 1956, Kyle et al. 1958, Bijvoet \& van der Sluys Veer 1968). PTH also induces an increase of the tubular resorption of calcium. But despite this elevated tubular resorption, as a rule a patient with hyperparathyroidism and a normal or only slightly disturbed kidney function will show hypercalcuria, because the tubular calcium resorption cannot keep pace with increased 
calcium concentration in the ultrafiltrate (Talmage \& Krainz 1954, Kleeman et al. 1958, Transbøl et al. 1968).

In the intestine PTH causes an increase of the calcium absorption (Rasmussen 1953, Talmage \& Elliot 1958, Lafferty \& Pearson 1963). The absorption of phosphate from the gut is also elevated (Borle et al. 1963). For the regulation of the plasma [Ca], however, these effects are of less importance.

Experiments with perfusion of the thyroid and parathyroid glands enabled Copp et al. (1962) to demonstrate the presence of a factor lowering the calcium level, which they called calcitonin (CT). For a proper understanding of the development of hypercalcemia in hyperparathyroidism, more must be known about the role played by calcitonin. Little is known, however, concerning the countereffect of calcitonin in hyperparathyroidism and its role in the pathogenesis of the hyperparathyroidism.

\section{Calcitonin and the C-cells}

Copp (1962) and Hirsch et al. (1963) have shown that the thyroid gland may be the source of calcitonin. Raymond (1932) and Nonidez (1932/1935) had previously described a certain type of cell in the thyroid gland; at the time this cell was called parafollicular, and after the discovery of calcitonin, the C-cell. Further research showed that these parafollicular cells undergo histochemical changes under the influence of hypercalcemia, which meant that they might be the source of calcitonin (Foster et al. 1964, Pearse 1966). This was confirmed by Bussolati and Pearse in 1967 by means of immunofluorescence studies. In the lower vertebrates the C-cells are situated in the ultimobranchial bodies (Copp et al. 1967, Tauber 1967). In man the C-cells probably derive from the ventral side of the 4th pharyngeal pouch. The latter attaches itself laterally to the thyroid gland developing from the floor of the mouth and is then incorporated into it. In the human adult they lie mainly dorsomedially in the lobes of the thyroid gland (Pearse \& Carcalheira 1967, Solcia 1969). But the C-cells can also be found extrathyroidally and even in the parathyroid glands (Galante et al. 1967). This might explain the fact that after a total thyroidectomy a normal CT level is sometimes found (Gudmundsson et al. 1966). The parathyroidal localization of calcitoninsecreting cells may possibly explain the slight initial decrease of plasma [Ca] sometimes seen as an effect of the administration of parathyroid extract, which has also been ascribed to the existence of a CT 'releasing factor' in the parathyroid gland (Haas 1964, Gittes \& Irvin 1965, Foster 1966, Gittes \& Radde 1966). 
In all likelihood, calcitonin occurs earlier in the evolutionary process than parathyroid hormone. Ultimobranchial bodies are also found in cartilaginous fish, which of course have no calcium-containing skeleton (Copp. et al. 1967, Talmage 1967, Tauber 1967).

That hypercalcemia constitutes a stimulus for the secretion of calcitonin has recently been conclusively demonstrated by Arnaud et al. (1970). The CT secretion stops when the plasma [Ca] drops to $0.5 \mathrm{mg} / 100 \mathrm{mI}$ below the physiological lower limit. Copp (1968) showed a linear relationship between the plasma [Ca] and the plasma [CT]. The half-life of calcitonin in vivo is estimated at 4 to 12 minutes (Potts 1967). In a brief and especially in a sudden hypercalcemia, the CT feedback mechanism seems to be very important (Toverud 1966, Copp 1968, Foster 1968). CT lowers the plasma [Ca] by inhibiting bone resorption. The effect of $\mathrm{CT}$ is dependent on the rate of bone formation, i.e. in mature bone the effect is not always demonstrable. It can be demonstrated in young bone or in bone where resorption has been stimulated by PTH or vitamin A and in bone of patients with Paget's disease (Milhaud et al. 1967, Bijvoet et al. 1968, Foster 1968).

On the kidney, calcitonin has a phosphaturic effect (Robinson et al. 1966, Morii \& Deluca 1967). In some patients with Paget's disease or osteoporosis, a rapidly appearing calcuric effect can be demonstrated (Bijvoet et al. 1970). It is not yet clear whether this is a direct effect or secondary to an increase in the PTH secretion resulting from the hypocalcemia (Bijvoet et al. 1968, Levin \& Bell 1968, Bordier 1969, Pak 1969). The effect of calcitonin on the renal calcium excretion is still controversial. In some patients with Paget's disease or osteoporosis, a rapidly appearing calcuric effect has been demonstrated (Bijvoet et al. 1970). 


\section{Chapter IV - Histology of the parathyroid tumors}

After the discovery of the primary chief cell hyperplasia (Cope et al. 1958), in which in principle all the parathyroids are affected, the differential morphological diagnosis between the nodular form of primary chief cell hyperplasia and adenomata proved to be extremely difficult. Currently, the diagnosis primary hyperplasia is made with increasing frequency (Cope 1966). The diagnosis of water-clear cell hyperplasia is generally not difficult (Black \& Utley 1968).

The series reported by Woolner et al. (1958), Cope et al. (1958), Roth (1962, his series), and Hellström and Ivemark (1962), comprise 620 cases showing the following distribution:

\begin{tabular}{lcc}
\hline & $\begin{array}{c}620 \text { patients } \\
(\%)\end{array}$ & $\begin{array}{c}343 \text { patients (Cope 1966) } \\
(\%)\end{array}$ \\
\hline Single adenoma & 83.0 & 77.0 \\
Multiple adenomata & 3.7 & 3.8 \\
Primary chief cell hyperplasia & 4.4 & 10.8 \\
Primary water-clear cell hyperplasia & 6.9 & 4.4 \\
\hline
\end{tabular}

Parathyroid carcinoma is the cause of primary hyperparathyroidism in 0.5 to $2 \%$ of the cases.

Cope's 1966 series comprises 343 cases, including his 1958 material. The distribution of the diagnoses of the 143 cases added from the material collected between 1958 and 1966 (obtained by subtraction) is:

\begin{tabular}{lcc}
\hline & $\begin{array}{c}143 \text { patients } \\
(\%)\end{array}$ & $\begin{array}{c}138 \text { patients (Lloyd 1968) } \\
(\%)\end{array}$ \\
\hline Single adenoma & 78.0 & 86.0 \\
MuItiple adenomata & 2.0 & 0.1 \\
Primary chief cell hyperplasia & 19.0 & 10.7 \\
Primary water-clear cell hyperplasia & $<1.0$ & $(<0.1)$ \\
\hline
\end{tabular}


The most recent series is that of Lloyd (1968). From comparison of all these values it is evident that:

a. the diagnosis multiple adenomata is now made less frequently;

$b$. the diagnosis primary chief cell hyperplasia is made with increasing frequency (25\% of Cope's later cases in 1966). Strauss and Paloyan (1969) even found a form of primary hyperplasia in $58 \%$ of their cases;

c. the diagnosis primary water-clear cell hyperplasia is rarely made any longer.

These differences could possibly be due to changes in the histological criteria applied for a given disease and in the morphological picture seen at earlier diagnosis. Both these factors are probably involved.

\section{§1. SINGLE ADENOMA}

Adenomata vary in weight between $100 \mathrm{mg}$ and $60 \mathrm{~g}$.

Macroscopically, the color of the adenoma is often an orange-brown but may vary from yellow to black. The surface is usually smooth and sometimes slightly lobular. Occasionally, calcification occurs in the capsule (Castleman 1952). In principle, there is no adhesion of the gland to surrounding tissue except in cases in which an operation has previously been performed in the region (Roth 1962).

Microscopically, the gland shows a sharply defined mass of adenomatous cells surrounded, in the ideal section, by a rim of 'normal tissue'. The adenoma tissue is usually composed of lightly stained chief cells or a mixture of chief, oxyphil, transitional water-clear, and water-clear cells. Classification of the adenoma is dependent on the criteria applied by the pathologist (Woolner et al. 1952, Rienhoff et al. 1968, Lloyd 1968). There seems to be no correlation between the dominant cell type and the clinical picture (Castleman 1952, Lloyd 1968).

\section{§2. MULTIPLE ADENOMATA}

There is no difference between the histological pictures of single and multiple adenomata (Roth 1962). The diagnosis double adenomata has been made with decreasing frequency since the discovery of primary chief cell hyperplasia and improved understanding of the distinction between these two pictures. Triple adenomata are exceedingly rare (Norris 1947). Adenoma formation in all four of the glands has only been reported once (Rubens et al. 
1969), but this has been criticized on fundamental grounds (Paloyan \& Reiss 1969).

\section{§3. PRIMARY HYPERPLASIA}

Primary water-clear cell hyperplasia: This diagnosis too tends to be made less frequently. Macroscopically, the glands are highly irregular in shape and show 'pseudopodial' protrusions. The color is chocolate-brown. All the glands are always affected, but the upper pair usually shows greater enlargement than the lower pair. Microscopically, the gland is composed of large water-clear cells. The picture may strongly resemble that of renal cell carcinoma (Castleman 1952, Woolner et al. 1952, Roth 1962).

Primary chief-cell hyperplasia: In the most typical case all the parathyroids are enlarged. The combined weight can amount to $25 \mathrm{~g}$. The glands have an irregular shape but seldom show pseudopodial protrusions macroscopically. The color is the same as is seen in adenoma. Microscopically, the gland consists of diffuse hyperplastic tissue composed of chief cells among which pale oxyphil and water-clear cells occur individually or in aggregation. A peripheral border of normal tissue cannot be demonstrated in the ideal case.

Secondary hyperplasia may be histologically impossible to distinguish from primary chief cell hyperplasia. Macroscopically, the gland is reported to have a more creamy-gray color in secondary hyperplasia (Castleman 1952, Cope et al. 1958, Roth 1962).

\section{§4. NODULAR HYPERPLASIA}

Nodular hyperplasia occurs more frequently than diffuse hyperplasia. The picture is characterized by one or more nodules surrounded by compact hyperplastic tissue (Graber \& Jacobs 1968, Rienhoff $e t a l .1968$ ), and is less uniform than that of chief cell hyperplasia. The term microadenoma is also used (Eder 1961a). The nodular character is increased by the presence of stroma (Roth 1962). Nodular hyperplasia is often found in multiple endocrine adenomatosis (Woolner et al. 1952) and familial hyperparathyroidism (Graber \& Jacobs 1968).

When the histological picture is less pronounced, the differentiation with respect to the so-called functional (i.e. secondary) focal hyperplasia is very difficult (Eder 1961a). When the glands show distinct pathological changes, differentiation with respect to multiple adenomata is often impossible 
(Block et al. 1967). Nodular hyperplasia probably represents a transitional form between diffuse chief cell hyperplasia and parathyroid adenoma (Black \& Utley 1968, Straus and Paloyan 1969).

Consequently, the clear-cut picture described for primary chief cell hyperplasia is far from universal. As a result, attempts have been made to establish clearly defined criteria for the differential diagnosis between chief celladenoma and primary chief cell hyperplasia. Some authors state that the presence of a rim of normal tissue on the 'capsule' of the neoplasm is characteristic of adenoma (Castleman 1952, Woolner et al.1952, Roth 1962, Block et al.1967), but this rim is absent in an appreciable proportion of the cases or sections (Cope et al. 1958, Lloyd 1968). Because of the formation of connective tissue occurring at more advanced ages, a hyperplastic gland may show a virtual rim of 'normal' tissue (Utley \& Black 1967, Black \& Utley 1968, Rienhoff et al. 1968). Therefore, the presence or absence of this normal rim around a tumor is not a reliable criterion for the differential diagnosis between primary chief cell hyperplasia and adenoma. Other characteristics, such as a decrease of the quantity of fatty tissue normal for a given age (Woolner et al. 1952), the structure of the gland, and the presence of polynuclear cells (Castleman 1952), are not conclusive for the diagnosis either, because these criteria too have only relative validity.

Since according to the original description given by Cope et al. (1958) all the glands are enlarged in primary chief cell hyperplasia, the presence of a normal gland is held to be the only remaining criterion for the diagnosis adenoma(ta) (Hellström \& Ivemark 1962, Roth 1962, Black \& Utley 1968, Lloyd 1968). Unfortunately, this too has given rise to objections (Block et al. 1967, Straus \& Paloyan 1969). Because a gland can be macroscopically normal but histologically hyperplastic, those who still maintain this 'absolute' criterion would nevertheless have to investigate biopsy samples of apparently normal glands to demonstrate adenoma in another gland (Bradshaw et al. 1964, Adams et al. 1965, Block et al. 1967, Black \& Utley 1968).

Because the histological picture of material prepared by frozen-sectioning may be difficult to evaluate, a conclusion on the above-mentioned grounds (no matter what the value attached to them) cannot be made until paraffin sections have been studied. In addition, the only diagnostically reliable material is provided by sections through the hilus, which of course can only be done in excized glands. Even then, the difference between a normal and a slightly hyperplastic gland may be very difficult to distinguish. Concomittant renal insufficiency confuses the picture even more, due to the possible secondary hyperplasia (Golden et al. 1965). These problems compli- 
cating the interpretation of the histological picture led Pyrah et al. (1966) to state that 'Under the heading of multiple adenoma there seems to remain an uneasy limbo containing the true multiple adenomata and the diffuse chief cell hyperplasia'.

Particularly when not all the glands can be located and when enlargement of glands is dubious, a definitive diagnosis is not possible. More certainty as to the nature of the tumors can only be reached after a prolonged follow-up period: the curative effect of total removal of multiple adenomata is permanent, but incomplete removal in primary hyperplasia could be followed by a recurrence after an interval of normocalcemia. Per-operative prediction in this respect is in any case impossible (Hellström \& Ivemark 1962, Bradshaw 1966, Utley \& Black 1967, Black \& Utley 1968, Graber \& Jacobs 1968, Rienhoff et al. 1968, Straus \& Paloyan 1969).

In our series the pathologist had exactly the same experience as described in the foregoing. In the first fifty patients (1950-1962) the diagnosis was almost exclusively adenoma or adenomata. After primary chief cell hyperplasia became known, this diagnosis was made with increasing frequency until finally mainly hyperplasia and nodular hyperplasia were found, even when only a single gland was macroscopically enlarged. At re-evaluation of the sections from the 1950-1962 period, hyperplasia was found in most cases.

To solve this problem, a comparative study was performed in normal parathyroid glands obtained at autopsy. The results showed that pathologically enlarged glands sometimes present a completely normal picture. Therefore, the differentiation between nodular hyperplasia and adenomata had to be considered unreliable. After arriving at this conclusion, we stopped recording the histological diagnosis and no longer took it into consideration with respect to treatment. The entire problem has been succinctly stated by the pathologist R. O. van der Heul: 'The best histological criterion is the weight of the gland'.

Nevertheless, the pathologist's opinion is indispensable for the surgeon. Only he can provide certainty about the nature of the biopsy material. For every structure resembling parathyroid tissue, a biopsy sample must be taken so that he can answer the question: Is this parathyroid? Confusion with lymph glands, aberrant thyroid gland tissue, and especially aberrant thymus tissue can lead to the failure of an operation. Only in two of our cases did this method prove inadequate: in one, a colloidal nodule of the thyroid gland was taken for parathyroid tissue and in the other, parathyroid tissue was not recognized. In both cases the true nature of the tissue was identified in the paraffin sections. 
The difficulties sometimes associated with the differentiation between thyroid and parathyroid tissue are also known from the literature (Hellström \& Ivemark 1962, Howell 1965).

It need hardly be said that this problem can strongly influence the course and results of the exploration.

\section{§5. CARCINOMA}

The parathyroid carcinoma showing endocrine activity is rather rare, comprising 0.5 to $2 \%$ of the parathyroid tumors. The tumor is usually larger than that of an adenoma and is palpable in the neck in at least $50 \%$ of the cases.

The clinical picture is characterized by the sudden onset of the complaints and a high plasma [Ca] (averaging $15 \mathrm{mg} / 100 \mathrm{ml}$ ) (Castleman 1952, Holmes et al. 1969). At operation, a striking feature is that the tumor is usually adherent to the surrounding tissues, in contrast to the situation in adenoma and primary hyperplasia. The tumor often has a grayish-white color and is highly irregular in shape. The cut surface is usually light to dark brown. These findings should alert the surgeon to the possibility of malignancy, since the frozen sections often do not provide conclusive information on this point. Tumoral growth is slow, and metastasis occurs preferentially in the lymphatic system. The clinical course is characterized by numerous reoperations because of cervical recurrences (Holmes et al. 1969). The microscopic picture and the clinical course are frequently divergent: mitotic figures, nuclear hyperchromasia, bizarre nuclei, and giant cells are described for benign parathyroid tumors, and metastases of parathyroid tumors showing no mitotic figures have also been reported (Woolner et al. 1952, Holmes et al. 1969). Therefore, only invasive growth into surrounding tissue (esophagus, trachea, neck muscles, recurrent laryngeal nerve) and metastasis are generally accepted as absolute criteria for carcinoma of the parathyroids (Woolner et al. 1952, Roth 1962, Lloyd 1968, Holmes et al. 1969, Kelly 1969).

Our material does not include even a single case of parathyroid carcinoma. 


\section{Chapter V - Pathogenesis of primary hyperparathyroidism}

\section{$\S 1$.}

According to the literature, a solitary adenoma is found in primary hyperparathyroidism in at most $80 \%$ of the cases, and more than one gland is involved in at least $20 \%$ (usually nodular chief cell hyperplasia). In our material more than one gland was affected in almost $45 \%$ of the cases.

For the discussion of the pathogenesis of primary hyperparathyroidism, the distinction according to the involvement of one and more than one gland or on the basis of solitary adenoma and primary hyperplasia, can be applied. Solitary adenoma can be seen as a local cellular derailment within a single parathyroid gland (to be left out of consideration here) and the hyperplasia resulting from a constant or intermittent stimulation of all the parathyroids (Castelman \& Mallory 1935). In view of the extremely small chance that a local derailment will occur in more than one of the parathyroids simultaneously, we are of the opinion that it is justifiable to call any case of primary hyperparathyroidism in which more than one gland is affected a form of primary hyperplasia.

Up to the present day, only one route has been demonstrated for the simultaneous stimulation of all the parathyroid glands, and that is hypocalcemia. How this hypocalcemia originates and subsequently gives rise to hypercalcemic hyperparathyroidism with its pathological substrate, will be discussed in this chapter.

Chronic stimulation of the parathyroid glands and incapacity for re-involution:

Prolonged hypocalcemia due to inadequate calcium resorption from the gut, an excessively high calcium excretion in the urine, and a reduced sensitivity to vitamin D in renal insufficiency, can given rise to a physiological parathyroid hyperplasia, i.e. 'secondary hyperparathyroidism. Whether or not the cause of this calcium loss persists, an autonomous hyperparathyroidism can develop (Davies et al. 1956, 1968, Dent 1962, McPaul et al. 1964, Wilson et al. 1964, McIntosh et al. 1966, Lameyer et al. 1967, Fisher et al. 1968, 1969, 
Jeremy 1968). St. Goar called this tertiary hyperparathyroidism (Castleman $\&$ Kibbee 1963). In this affection, adenoma formation in one or more glands is seen in some of the patients. In primary as well as in tertiary hyperparathyroidism, hyperplastic glandular tissue showing only hyperplastic changes can show autonomous behavior. In spite of the hypercalcemia, the PTH secretion is too high and after some time (months) shows no tendency to decrease, even after calcium infusion. In secondary hyperparathyroidism, the PTH level does fall after calcium infusion (Berson \& Yalow 1966).

The experiments of Gittes and Radde (1966) have shown that an erroneous evaluation of the histological substrate is not involved here: multiple isologous parathyroid transplantations in inbred rats resulted in a distinct hyperparathyroidism. After 24 days there was still no tendency for hypercalcemia to diminish. This hyperparathyroidism is probably to be attributed to an excess of normal parathyroid tissue whose function and quantity are not reduced by hypercalcemia. This assumption is supported by the fact that neither in hypercalcemia due to bone metastases nor in pseudohyperparathyroidism can involution of the parathyroid glands be demonstrated (Svane 1964, Horeau et al. 1965, Seftel \& Gusberg 1965, Kohout et al. 1966, Sherwood et al. 1967). Basal functioning of the parathyroids in hypercalcemia has been demonstrated (Schmidt et al. 1966). In hypercalcemia the cell itself shows only a reduction in the amount of cytoplasm (Raisz 1963). Adequately sensitive methods to measure PTH are not yet available to make it possible to prove that in hypercalcemia a basal PTH excretion persists. The genesis of hyperparathyroidism can be understood better on the basis of the following hypothesis: hypocalcemia gives rise to hypertrophy of the parathyroid cells and to hyperplasia (i.e. an increase of the amount of normal parathyroid gland tissue), as a result of which an increased basal PTH secretion develops, which in turn gives rise to the clinical picture of hyperparathyroidism. This hypothesis is in agreement with the statistical finding that the plasma [Ca] is higher the higher the weight of the tumor (Hodkinson 1963, Lloyd 1968). It is not excluded, however, that over a longer period (months) a re-involution of the parathyroid glands may occur (Alfrey et al. 1968, Jowsey \& Raisz 1968).

Thus, chronic hypocalcemia can be the cause of (tertiary) hyperparathyroidism. It is not clear what percentage of the cases we call primary hyperparathyroidism are actually tertiary, either because there has been an unrecognized period of external inducement of hypocalcemia, e.g. by vitamin D deficiency (Dent 1962), or some unknown factor or factors. In many cases of primary hyperparathyroidism there is a concomittant disease whose relationship with the hyperparathyroidism is obscure (Davies et al. 1968). 
Primary hyperparathyroidism occurs about twice as often in women as in men. No causal relationship with gravidity and lactation can be demonstrated (Hellström \& Ivemark 1962). In children there is no predilection for either sex (Mühlethaler et al. 1967); this is confirmed up to the age of 45 by our material. These findings make it interesting to consider the role that other hormones involved in calcium metabolism could play in the pathogenesis of primary hyperparathyroidism.

\section{§ 2. HYPERPARATHYROIDISM AND OTHER HORMONAL FUNCTIONS}

\section{Calcitonin}

In short-lasting hypercalcemia, the CT feedback mechanism is of great importance (Toverud 1966, Copp 1968, Arnaud et al. 1970). In chronic hypercalcemia, whatever the cause, the functioning of this system is apparently so disturbed that redressment to normocalcemia by CT is no longer possible. There are two possible reasons for this:

a. The CT production is adequate but the site of its effect is less sensitive for the hormone. This is in contradiction with the reported effect of $\mathrm{CT}$ on active bone as expected in hyperparathyroidism (see p. 16).

b. The CT production is inadequate: in chronic hypercalcemia the C-cells do not produce sufficient CT to compensate for the primary disorder. The CT level in the thyroid gland in primary hyperparathyroidism does not provide conclusive information about this (Tashjian \& Voelkel 1968). Focal and diffuse $\mathrm{C}$-cel hyperplasia have been demonstrated in hyperparathyroidism (Kuhlencord \& Kracht 1968, Kracht \& Hachmeister 1969, Young 1969). In three patients with hyperparathyroidism, an elevated plasma [CT] level was found twice (Gudmundsson et al. 1969). After injections of calcitonin, the hypercalcemia of hyperparathyroidism decreases.

This points to a deficiency in the endogenous CT production under these conditions. Gittes demonstrated in a very elegant series of experiments that this probably depends in part on the quantity and not solely on the quality of the C-cells. An increase of plasma [CT] in experimental hyperparathyroidism in the rat leads not only to a reduction of the hypercalcemia but also to a decrease of plasma $\left[\mathrm{PO}_{4}\right]$ and calcium excretion. At the same time, far fewer bladder stones are formed (Gittes \& Radde 1966, Gittes $\&$ Wells 1967). The long-term clinical course in a patient with primary hyperparathyroidism kept normocalcemic by CT injections remains an open 
question. Insufficient research has also been done on the influence exerted by the endogenous $\mathrm{CT}$ production in hyperparathyroidism on the changes in bone and kidney.

\section{Hypercalcitoninemia}

The coincidental occurrence of CT-producing medullary thyroid gland carcinoma and parathyroid gland tumors, pheochromocytoma, and possibly neurofibromatosis has been reported (Sipple 1961, Sarosi \& Doe 1968), but this can only be seen as a sporadic cause of (secondary) hyperparathyroidism, because C-cell carcinomas are rare (Williams et al. 1966, Melvin \& Tashjian 1968, Heimann et al. 1970). In one of our patients, too, a medullary thyroid carcinoma was removed during a successful parathyroidectomy. In her sister (not included in the present series) a medullary thyroid gland carcinoma was also resected many years later, marked enlargement of one of the parathyroids being observed at operation.

\section{Thyroxin}

This hormone increases calcium turn-over of the bone. Hyperthyroidism can be accompanied by hypercalcemia and osteoporosis, and hypocalcemia can develop in hypothyroidism. Hyperparathyroidism is often accompanied by disorders of the thyroid gland (non-toxic goiter, thyroid gland carcinoma, adenoma, or thyrotoxicosis) in as much as $40 \%$ of the cases (Hellström \& Ivemark 1962, Adams \& Murphy 1963, Werdelin 1964, Block et al. 1967, Davies et al. 1968, Heimann et al. 1970b). Here there is perhaps no question of a thyroid gland disease found accidentally during parathyroidectomy (Laing 1969), but the pathogenetic relationship is obscure. A possible explanation would be a stimulation of the parathyroids due to hypocalcemia in (transient?) hypothyroidism. Besides the medullary thyroid gland carcinoma, we found thyroid anomalies in 51 patients $(20 \%)$ with demonstrated hyperparathyroidism. In 43 of these patients a nodular dysplastic goiter with euthyroidism was found. In 3, Hashimoto's disease was demonstrated and in 2 hypothyroidism with certainty, one of the latter on the basis of thyroid gland aplasia. Theoretically, in these patients the occurrence of parathyroid gland stimulation due to diminished sensitivity of the bone for PTH in hypothyroidism cannot be excluded. Two patients also had hyperthyroidism; this combination is also known from the literature (Bortz et al. 1961, Breuer et al. 1966). In one patient in our series a thyroidectomy was later performed for papillary carcinoma (see Table II). 
Table II. Thyroid gland anomalies in 52 patients with primary hyperparathyroidism

No. of patients

\begin{tabular}{lr}
\hline Nodular goiter (dysplastic) & 43 \\
Hashimoto's disease & 3 \\
Hyperthyroidism & 2 \\
Hypothyroidism & 1 \\
Thyro-aplasia & 1 \\
Papillary carcinoma & 1 \\
Medullary carcinoma & 1 \\
\hline Total & 52 \\
\hline
\end{tabular}

\section{Corticosteroids}

Corticosteroids also influence calcium metabolism. In Addison's disease hypercalcemia may be present, in hypercorticism an osteoporosis, usually with normocalcemia. Corticosteroids have an antagonistic effect on the effect of PTH, but how this operates is not known (Robinson \& Walser 1964, Eliel 1965, Wajchenbach et al. 1965, Jowsey \& Simons 1968). It was recently found that calcitonin production is possibly inhibited by corticosteroids (Azzali 1969, Gozarin 1969). It is conceivable that there is a calcitonin-like factor in the adrenal gland (Kaplan 1969). In Cushing's disease a pathogenetic relationship with primary hyperparathyroidism has been suspected but never demonstrated. The coincidence of these two clinical pictures occurs only in multiple endocrine adenomatosis. Cushing's disease and iatrogenic overdosage of corticosteroid can coincide with osteoporosis, but a significant relationship with hyperparathyroidism has not been demonstrated. This combination did not occur in our material.

\section{Growth hormone}

Acromegaly may be accompanied by hypercalcemia and hypercalcuria. The combination with hyperparathyroidism, generally caused by chief cell hyperplasia, is known (Hubner 1967). This usually concerns a form of multiple endocrine adenomatosis in which a colloidal goiter is not infrequently found (Hartog et al. 1967). Some authors think that the cause lies in a genetic error (Vancil \& Locke 1965). Summers et al. (1966) believe, to the contrary, that the parathyroid hyperplasia is secondary to the 
acromegaly, because in their case the hypercalcemia disappeared after treatment of the hypophyseal tumor.

A possibly unrecognized factor in the pathogenesis might be constituted by an as yet undemonstrated parathyroid-stimulating hormone. In our material there are two cases of acromegaly with hyperparathyroidism.

\section{Multiple endocrine adenomatosis and familial hyperparathyroidism}

In multiple endocrine adenomatosis various combinations of parathyroid, Langerhans' cell, hypophysial, thyroid, and adrenal hyperplasia, as well as adenomas, occur in a single syndrome. The clinical picture consists of the coincidental occurrence of hyperparathyroidism, the Zollinger-Ellison syndrome, insulinoma, acromegaly, hyperthyroidism, and Cushing's disease, in all possible combinations (Wermer 1954, 1965). It is often difficult if not impossible to explain the simultaneous occurrence of one or more of these diseases, sometimes themselves causing hypercalcemia, in combination with hyperparathyroidism, on the basis of chronic hypocalcemia.

Multiple endocrine adenomatosis often occurs familially (Wermer 1954, 1963, Ellison \& Wilson 1964, Dutta et al. 1968, Renwick et al. 1968). Familial hyperparathyroidism without other endocrinopathy has often been described (Adams et al. 1965, Graber \& Jacobs 1968). In this affection, as in multiple endocrine adenomatosis, all the parathyroids are usually enlarged (Cope $e t$ al. 1958). It is possible that both are autosomal dominant hereditary diseases with an anomaly in the same gene (Cutler et al. 1964, Schachter et al. 1966).

There are two possible explanations for these patterns; a hereditary defect in the mechanism regulating cell growth in the above-mentioned organs or a defect in the feedback mechanism controlling the hormone production and therefore affecting these organs.

This again raises the question of whether, in addition to hypocalcemia, a parathyroid-stimulating factor (hormone?) exists. This hypothetical hor mone could explain the occurrence of hypercalcemia in parathyroid hyperplasia, as seen in multiple endocrine adenomatosis.

A possible relationship between the excretion of PTH and that of thyroxin, corticosteroids, and growth hormone has already been discussed, which leaves the influence of the pancreas on calcium metabolism to be treated.

The pancreas and hyperparathyroidism

Hypocalcemia as a complication in acute pancreatitis is a well-known 
phenomenon and is ascribed to saponification of calcium ions. This is not the only cause, however, In acute and intermittent pancreatitis an elevated plasma glucagon level is found, and hyperglucagonemia can lead to hypocalcemia (Paloyan et al. 1967a,b). How this effect is induced is not clear. Alvioli (in Foster 1968), Melvin and Tashjian (1969), and Care (1969) have ascribed it to the liberation of CT from the C-cells by glucagon.

Bowser (1968) saw the hypocalcemic effect of glucagon after thyro-parathyroidectomy as well. Bernstein (1969) considers the presence of the thyroid gland unnecessary but that of the parathyroids to be essential for this induction. Williams et al. (1969) demonstrated that glucagon lowers the serum calcium level by promoting the uptake of calcium by the skeleton. It is known that calcitonin inhibits the release of calcium from bone. The hypocalcemic effect of glucagon injections has been proven (Berge \& Alvioli 1969). Paloyan et al. (1967a) succeeded in inducing parathyroid hyperplasia within six weeks in rabbits by glucagon injections. Recently, we have seen a patient with Cushing's disease, hyperparathyroidism, and a glucagonproducing tumor in the pancreas.

In pancreatitis, stimulation of the parathyroid glands is promoted not only by calcium-ion saponification and hyperglucagonemia but also by steatorrhea, which is caused by exocrinic pancreatic insufficiency after recurrent pancreatitis. The parathyroid gland stimulation is then the result of inadequate vitamin $\mathrm{D}$ and calcium resorption from the gut (Davies et al. 1956, 1968, Fisher et al. 1968). However, it may be difficult to distinguish cause from effect here, i.e. whether primary or tertiary hyperparathyroidism is concerned, since hyperparathyroidism can be complicated by intercurrent acute pancreatitis (Steyn et al. 1966, McLeod \& Holloway 1967, Kelly \& Falor 1968, Marks 1968, Warshaw et al. 1968). Carey and Fitzgerald (1968) have even described the familial occurrence of hyperparathyroidism with pancreatitis. Our series includes only one case of acute pancreatitis, which was diagnosed the day after the cervical operation.

\section{Sex hormones}

Primary hyperparathyroidism occurs preferentially in women in the menopause (Muller 1969). Consequently, an estrogen deficiency must be taken into consideration as a possible cause of primary hyperparathyroidism. The plasma $\left[\mathrm{PO}_{4}\right]$ values and the phosphate excretion index do not, however, provide any indications for the existence of increased parathyroid activity in the menopause. Women in menopause, whether natural or artificial, are more likely to develop osteoporosis than men of the same age 
(Davis et al. 1966, Nordin et al. 1966). The histological characteristics and the chemical composition of the bone (Birkenhäger \& Birkenhäger-Frenkel 1968) are not the same in advanced senile osteoporosis and hyperparathyroidism, however. Therefore, the finding of the more frequent occurrence in women in the menopause does not contribute to the solution of the problem of the pathenogensis of primary hyperparathyroidism and senile osteoporosis.

The explanation of this finding can at most be that women in menopause show a greater susceptibility for the development of primary hyperparathyroidism or for a facilitated occurrence of the symptomatology than is the case for men of the same age.

\section{Other diseases}

Sarcoidosis is a non-hormonal disease that can occur together with primary hyperparathyroidism (Dent 1966, Pedersen 1967), but it is not clear whether there is a pathogenetic relationship between the two diseases involving a disturbance of the calcium balance or whether the concurrence is a matter of chance (Winnacker et al. 1969). Our series includes only one case of sarcoidosis, a woman with a demonstrated hyperparathyroidism in whom the diagnosis sarcoidosis was made as the result of a re-exploration made necessary by a possible recurrence of the hyperparathyroidism (see page 71).

One of our patients in whom surgical treatment had been successful died later of a multiple myeloma. A similar case has been described by Cosgrove and Latourette (1953). Other concomittant diseases in our series were one case of mammary carcinoma, one of diabetes insipidus, and one of cholelithiasis. In view of the low frequency of the occurrence of these diseases in our material, we think the concomittance to be coincidental. We have also been unable to find reports of more than incidental concomittance in the literature.

\section{§3. HISTOPATHOGENESIS}

In addition to the local cell derailment in one parathyroid gland, which is expressed as a true solitary adenoma or parathyroid carcinoma, there is the primary hyperplasia. There are three hypothetical explanations for the simultaneous occurrence of hypercalcemia and primary hyperplasia;

a. Incapacity for re-involution after hypocalcemia.

$b$. A defect in the growth regulation of all parathyroid cells.

c. A defect in the feedback mechanism of PTH secretion. 


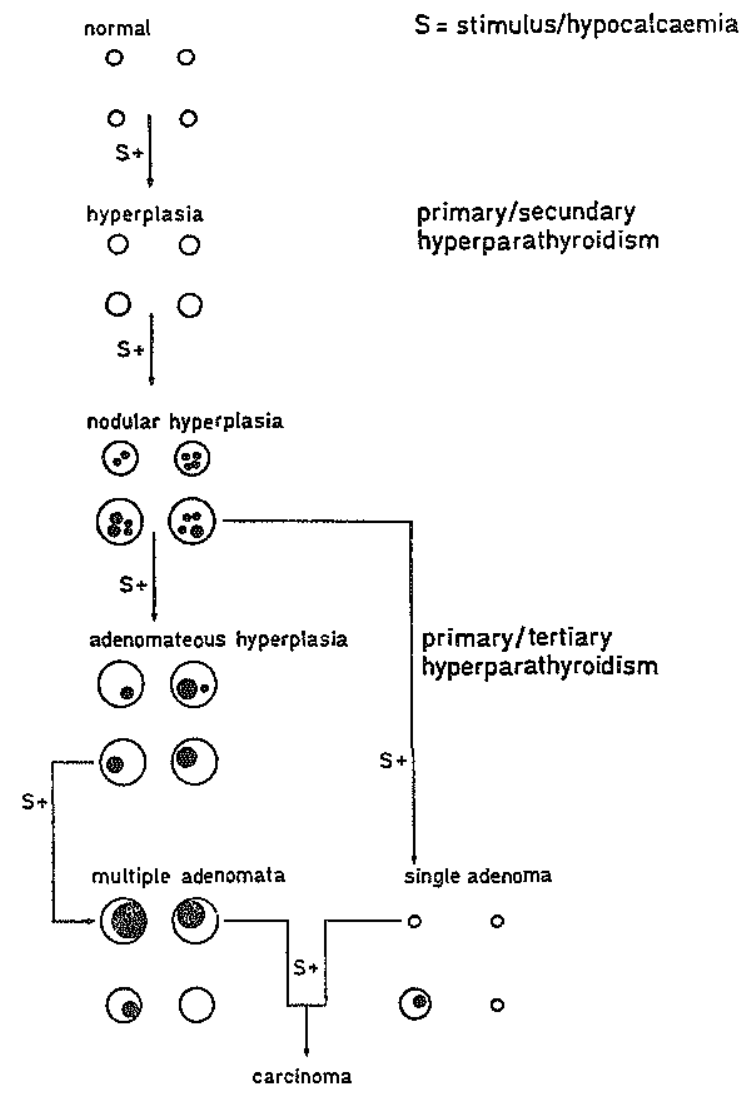

Fig. 1. Possible histopathogenesis of parathyroid tumors

For the last two of these possibilities, a hereditary factor could be responsible It is not known, however, how often an external, partially obscure stimulus forms the pathogenetic moment.

The most likely histopathogenesis of the parathyroid tumors in the presence of a chronic or intermittent stimulus is: normal $\rightarrow$ hypertrophy and hyperplasia $\rightarrow$ nodular hyperplasia $\rightarrow$ adenoma(ta) $\rightarrow$ carcinoma (Cope $e t$ al. 1958, Dent 1962, Golden et al. 1965, Black \& Utley 1968, Davies et al. 1968, Lloyd 1968, Kramer 1970). Between the transition from hypertrophy and hyperplasia to adenoma formation nodular hyperplasia might be considered an expression of dysplasia (Dr. R. O. van der Heul, personal communication).

As already mentioned, it is not impossible that in prolonged hypercalcemia 
a certain degree of re-involution could occur, so that in long-term hyperparathyroidism, parathyroid tissue that has become autonomous, via the hypercalcemia forces the hyperplastic tissue to re-involution (see Fig. 1). Once this has occurred, the single adenoma has originated. The reason why we see more and more hyperplasias or enlargement of all the glands would be that for the development of the observed histological picture a certain lapse of time and thus a certain duration of the disease is required.

The earlier the diagnosis hyperparathyroidism is made, the more often hyperplasia will be found (Cope et al. 1958), the later the more often adenoma. This is in agreement with the current more rapid and earlier recognition of hyperparathyroidism and with the fact that enlargement of more than one gland is found with increasing frequency.

This conception of the histopathogenesis again raises the problem of our lack of information concerning the stimulus leading to parathyroid hyperplasia. If the development of the histological picture is not the result of hypocalcemia alone but of other factor as well, the pattern and duration must be determined by the opposite influences of these factors and a possible hypercalcemia. 


\section{Chapter VI - Suspicion and diagnosis of hyperparathyroidism}

$\S 1$.

Before specific steps can be taken to arrive at a diagnosis, hyperparathyroidism must be suspected. The first step is extremely difficult. In early cases the symptomatology is vague. Bradshaw (1966) calls the disease 'the syphilis of the endocrine system'. It often amounts to a summation of symptoms pointing in the direction of hyperparathyroidism (Cope 1966). These symptoms are caused by the hypercalcemia (Swyer et al. 1950), nephrolithiasis, kidney function disorders, and bone anomalies (Smeenk \& Muller 1961). Familiarity with the clinical picture has led to earlier diagnosis at present. As a result, there has been a change in the relevant symptoms described by St. Goar (1957) as 'a disease of stones and bones ... recognized earlier and more frequently ... as a disease of stones, bones, and abdominal groans', to which Mieher et al. (1961) added 'psychic moans' and Boonstra and Jackson (1956) 'fatigue overtones'.

Another comparison with syphilis can also be made. In asymptomatic lues the disease process can show marked progression, although only the serological reactions are positive. Similarly, we know asymptomatic hypercalcemia with progressive nephrocalcinosis and impaired kidney function. Nephrolithiasis, too, does not always produce symptoms. Since early diagnosis can prevent potentially lethal kidney damage or keep it to a minimum, it will be useful here to mention the signs and symptoms that should cause suspicion of hyperparathyroidism (Cope 1966, Graham \& Royster 1967). It should be said first and foremost that when there is even the least doubt, the indication for determination of the plasma [Ca] is already present.

\section{Kidney stones:}

Retrospectively, urolithiasis is found to occur in hyperparathyroidism in about $70 \%$ of the cases (Cope 1966, Smeenk 1968), and 2.5 tot $5 \%$ of all patients with kidney stones have hyperparathyroidism (McGeown 1963, 
Adams et al. 1965). Suspicion should certainly be entertained when there are bilateral and recurrent kidney stones containing calcium, especially when no local cause, such as obstruction or infection, is present (Keating 1962, Hodgkinson \& Edwards 1963, Bartelheimer \& Kuhlencordt 1967, Sonoda et al. 1967, Yendt \& Gagné 1968).

\section{Digestive tract:}

Weight loss due to anorexia, nausea and vomiting, constipation, polydipsia, and polyuria, may offer the only key to the diagnosis (Mieher et al. 1961, Cope 1966). Stomach complaints vary from vague pain to the typical peptic ulcer complaints and those associated with acute pancreatitis.

The number of ulcer patients among the hyperparathyroidism patients is not known with certainty. The reports range from 8 to $43 \%$ (Cope 1966, Marks 1968, Myers \& Bhatti 1970). Typical ulcer complaints are not always accompanied by a radiologically demonstrable lesion (St. Goar 1957). It has never been conclusively demonstrated that the occurrence of peptic ulcer is promoted by hyperparathyroidism (Gray 1964). In all likelihood, gastrin production is unremittingly stimulated by hypercalcemia (Trudeau \& McGuigan 1969).

But ulcer cases have two striking aspects that make the presence of hyperparathyroidism more probable:

$a$. when the complaints do not improve or even become worse on a milk diet (Keating 1962, Katz et al. 1964), and

b. when a duodenal ulcer is demonstrated in a woman (Gray 1964, Goldsmith et al. 1966, Ellis \& Nicholoff 1968).

\section{Pancreatitis:}

Pancreatitis can, albeit infrequently, be an expression of hyperparathyroidism, especially when no cause can be demonstrated for the pancreatitis (Cope 1960, Coffey et al. 1965, Marks 1968). This may concern the form of hyperparathyroidism called parathyroid intoxication (Kelly \& Falor 1968). Therefore, a normal plasma [Ca] in a patient with a severe acute pancreatitis is suggestive of hyperparathyroidism, and it is advisable to determine the plasma [Ca] regularly during convalescence (Coffey et al .1965).

Neurological and psychiatric phenomena:

When sought for, hypotonia and myasthenia are found (Cope 1960, Buge \& 
Mignot 1964, Smith \& Stern 1967, Frame et al. 1968). Subjective findings such as weakness, headache, fatigue, apathy, lack of initiative, and depression develop gradually (Karpati \& Frame 1964, Anderson 1968, Petersen 1968). Hypercalcemic crises are often accompanied by alarming phenomena such as disorientation, psychosis, and coma (Horeau et al. 1965, Bauermeister et al. 1967, Marks 1968). Such patients sometimes are even placed in psychiatric institutions.

\section{Electrocardiogram:}

When the plasma [Ca] rises above $12.5 \mathrm{mg} / 100 \mathrm{ml}$, a pathological shortening of the QT interval occurs (Cope 1960, Boen et al. 1962).

\section{Metastatic calcifications:}

Not only nephrocalcionosis but also calcification of the conjunctiva, ear drum, and peripheral arteries may occur. Bandkeratopathy may also develop due to calcification (Cogan et al. 1948, Cogan \& Henneman 1957, Coffey et al. 1965).

\section{Neonatal tetany:}

Neonatal tetany may be the only expression of maternal hyperparathyroidism. It is caused by a secondary hypoparathyroidism in the infant, leading to hypocalcemia, sometimes with hypomagnesemia (Ertel 1969). The earliest convulsions may occur in the third week after birth (Mannix \& Loer 1968, Rubin et al. 1968), but sometimes much later (Friderichsen \& Rosendal 1968).

\section{Bone:}

Like bone pain, bone cysts (brown tumors), resorption of the lamina dura, and malocclusion are not early symptoms of hyperparathyroidism. Nevertheless, when they cannot be explained in any other way, they may suggest hyperparathyroidism to the dentist or otorhinolaryngologist (Boyle 1962, Thompson 1964, Anderson \& Lindholm 1967, Houston et al. 1968).

\section{Multiple endocrine adenomatosis:}

Patients suffering from acromegaly, hyperthyroidism, insulinoma, ZollingerEllison's syndrome, Cushing's disease, or any combination of these diseases 
should be investigated for hyperparathyroidism (Wermer 1954, 1963, Vancil \& Locke 1965). This also holds for all forms of thyroid disease (Feind 1964, Laing et al. 1969, Heimann et al. 1970 b).

\section{Familial hyperparathyroidism:}

When a patient suffering from hyperparathyroidism has a suggestive family history (e.g. ulcers, urolithiasis), further investigation of kin is certainly to be considered (Cutler et al. 1964, Schachner et al. 1966, Graber \& Jacobs 1968).

\section{§2. THE DIAGNOSIS}

As a rule, the diagnosis primary hyperthyroidism is made by exclusion and is only confirmed in the last phase, i.e. the exploration. Many authors are in agreement that the demonstration of hypercalcemia is fundamental for the diagnosis (Keating 1962, The Lancet: Leading Article 1965, Graham \& Royster 1967, Smeenk 1968).

This is where the first difficulties arise. The patient's plasma [Ca] may fluctuate, so that this determination should be done repeatedly (Hodgkinson \& Edwards 1963, Sonoda et al. 1967, Renwick et al. 1968, Finby \& Begg 1969). A correction must be made for determination errors caused by hemoconcentration (Cope 1960, McGeown 1961, Dent 1962). Hemoconcentration (due to venous congestion) causes a rise in the plasma [Ca] proportional to the total protein in the plasma. For each gram that the total protein increases per $100 \mathrm{ml}$ plasma due to hemoconcentration, the total plasma [Ca] rises by $0.5 \mathrm{mg}$ calcium per $100 \mathrm{ml}$ plasma (Smeenk \& van den Brand 1965, Smeenk 1968). Furthermore, hypercalcemia may be masked or compensated by high phosphate intake (Eisenberg 1968), hypalbuminemia, impaired renal function, or acute pancreatitis.

There is also the possibility of normocalcemic hyperparathyroidism, which can give rise to the same complications as hypercalcemic hyperparathyroidism (Keating 1962, Nichols \& Flanagan 1967, Eisenberg \& Goth 1968, Melvin et al. 1968, Fisher et al. 1969, Wills et al. 1969).

The hypercalcuria, elevated renal phosphate clearance, and hypophosphatemia occurring in primary hyperparathyroidism may be absent (even with adequate kidney function) but can also occur without hypercalcemia in the so-called idiopathic hypercalcuria. A specific functional test for the demonstration of an autonomous hyperfunction of the parathyroid glands is therefore urgently needed, but a test of this kind is not yet available. It has indeed been remarked in a leading article in The Lancet that: 'The 
number of diagnostic tests varies inversely with their specificity. Thus, tests for primary hyperparathyroidism abound'.

A solution to these problems seemed to be offered by the use of a radioimmunoassay for direct measurement of the plasma [Ca], but overlapping proved to occur between the values found in normals and in patients suffering from hyperparathyroidism. In about $50 \%$ of the investigated patients a normal plasma [PTH] was found. Furthermore, the PTH levels are higher in secondary than in primary hyperparathyroidism (Berson \& Yalow 1967, Egdahl 1968, Lequin 1969, Arnaud 1970, Arnaud et al. 1971).

When hypercalcemia is demonstrated either by chance or preferably by screening in a patient with nephrolithiasis and/or skeletal changes as well as a so-called hypercalcemia syndrome, the only course open - in view of the lack of adequately reliable positive diagnostic methods - is to attempt to exclude the numerous causes of hypercalcemia other than primary hyperparathyroidism (see e.g. Smeenk \& Muller 1961, Keating 1962). These include sarcoidosis, myelomatosis, carcinomatosis with or without radiographically demonstrable skeletal metastases, reticulosis, leucemia, immobility osteoporosis, Paget's disease with immobilization, hypercortisolism, hyperthyroidism, adrenal insufficiency, vitamin D intoxication, and the milk-alkali syndrome in peptic ulcers.

The anamnesis, physical examination, and routine tests will of course determine the direction in which the differential diagnosis must be sought, for example the finding of hepato-splenomegaly or swelling of lymphatic glands (or radiographically only of the hilus glands). Particularly in sarcoidosis but also in most of the other conditions, the plasma [Ca] can be normalized with the so-called cortisone test according to Dent $(1961,1968)$. The protein spectrum may provide indications with respect to sarcoidosis and myelomatosis, The tuberculin test results should be considered too. The radiological investigation of the skeleton can give clues pointing to myelomatosis or carcinomatosis of the skeleton. In rare cases the radiograms may offer specific indications for primary hyperparathyroidism itself.

Cytological or histological investigation of the bone marrow (with respect to myelomatosis, reticulosis, skeletal metastases, or aleucemic leucemia) will only be required in a minority of the cases. When there is any doubt at all, it is advisable to apply a reliable parameter for the thyroid gland function, such as P.B.I. or total thyroxin content. Adrenal insufficiency, which never is accompanied by a severe hypercalcemia, is easy to recognize clinically. Excessive use of vitamin D or of milk and alkali can as a rule be detected from the history.

Positive diagnostic data - albeit not always specific for primary hyper- 
parathyroidism (see e.g. Goldsmith 1969) - can be found in the form of hypophosphatemia, an elevated serum alkaline phosphate level, elevated phosphate clearance or depressed tubular resorption of phosphate, increased excretion of hydroxyproline in the urine, and radiological signs of bone resorption at certain sites of predilection such as the cortices of the phalanges, the distal ends of the clavicles, and the lamina dura of the tooth sockets. The presence of hypercalcuria has virtually no differential-diagnostic importance in relation to the hypercalcemia. When necessary, these diagnostic methods can be supplemented by histological investigation of a biopsy sample from the iliac crest, since it has been found that in a high percentage of the cases (i.e. even when no skeletal changes can be demonstrated radiographically) in primary hyperparathyroidism the bone shows signs of increased formation and destruction expressed in, among other things, an increased uptake of tetracyclin (van der Sluys Veer et al. 1964). The possibilities and limitations offered by the radio-immunological determination of the parathyroid hormone level in the serum has already been discussed above.

A special diagnostic problem is formed by the syndrome of the ectopic parathyroid hormone production, sometimes called pseudo-hyperparathyroidism (Lafferty 1966). Although this is well known for carcinoma of the kidney, bronchus, and ovary, and for reticulosis, the syndrome can develop in many other malignant processes. Even in cases of long-standing hyperparathyroidism, the possibility of renal carcinoma should be excluded.

With all this, however, we have barely touched on the diagnostic problems associated with hyperparathyroidism. The decision to operate must never be taken except on the broadest possible basis, which will be discussed exhaustively in the publication already referred to (D. Smalbraak, in preparation). 


\section{Chapter VII - Incidence of primary hyperparathyroidism}

Ten years ago, primary hyperparathyroidism was still considered to be a relatively rare disease. Autopsy results have shown, however, that the diagnosis is often missed during the patient's life (Norris et al. 1947). Bay et al. (1967) found a parathyroid adenoma in $2 \%$ of a series of 350 routine autopsies, and Vail et al. (1967) primary and secondary enlargement of the parathyroid glands in $12 \%$ of a similar series of 200 . In addition, parathyroid tumors are sometimes found by chance during thyroid gland operations (Feind 1964, Attie et al. 1967, Davies et al. 1968, Laing et al. 1969, Heimann et al. 1970a).

A case of this kind occurs in our material. A 49 year old woman underwent a hemithyroidectomy on the left side. Pre-operatively, both the plasma [Ca] and alkaline phosphatase value were normal $(9.4 \mathrm{mg} / 100 \mathrm{ml}$ and 10.8 U.K.A., respectively). At operation, besides a diffuse, nodular goiter, enlargement of the left parathyroid glands (400 $\mathrm{mg}$ and $100 \mathrm{mg}$ ) was found. A hemithyroidectomy on the left and a resection of $2 \frac{1}{2}$ parathyroid glands were performed. Postmoperatively, the plasma [Ca] was 8.3-9.4 mg/100 mg. The pathologist's report read: water-clear cell hyperplasia of the parathyroid glands, nodular dysplasia of the thyroid. Previously, this patient had never had a single complaint pointing in the direction of hyperparathyroidism.

There are cases in which suspicion of the disease arises because of a coincidental determination of the plasma [Ca] (Dent 1962, Keating 1962). Since the introduction of routine calcium determination in all patients, primary hyperparathyroidism has been diagnosed much more frequently (McLellan et al. 1968, Myers \& Bhatti 1970). Boonstra and Jackson (1965) give a good impression of the incidence of the disease: in 25,847 successive patients, determination of the plasma [Ca] led to the diagnosis of primary hyperparathyroidism in 31 cases. This study did not include patients referred for further evaluation of a hypercalcemia. It was also found that 23 of these 31 patients had had only vague complaints. In a similar study in 2,005 patients, Keating et al. (1969a) found 7 cases of hyperparathyroidism, 3 of which had had an asymptomatic course. Thus, the incidence of 
primary hyperparathyroidism among hospital out-patients appears to be of the order of 1.2 to $3.5 \% ; 0.9$ to $1.5 \%$ of the patients had an asymptomatic or symptom-poor form of primary hyperparathyroidism. These data seem to provide sufficient argumentation for the importance of routine determination of the plasma [Ca].

Age: Primary hyperparathyroidism can develop at any age. It is rare in children as well as after the age of 75 (Fanconi \& Mieth 1967, Mühlethaler et al. 1967). The highest frequency is found in the age-group of 30-65 years (Norris 1957, Cope 1960). This also holds for our material.

Sex: Primary hyperparathyroidism occurs twice as often in women as in men (Cope 1960, Hellström \& Ivemark 1962, Lloyd 1968), but before puberty there is no preference for either sex (Mühlethaler et al. 1967). For the first 200 patients of the present series, after correction for the composition of the population, Muller (1969) reported a slightly higher frequency in male than in female patients up to the age of 45 . After this age, however, there is a sharp increase in the incidence in women (see Fig. 2).

In men the normal upper limit of the plasma [Ca] drops with increasing age, but this shift is not seen in women. Keating et al. (1969b) found the

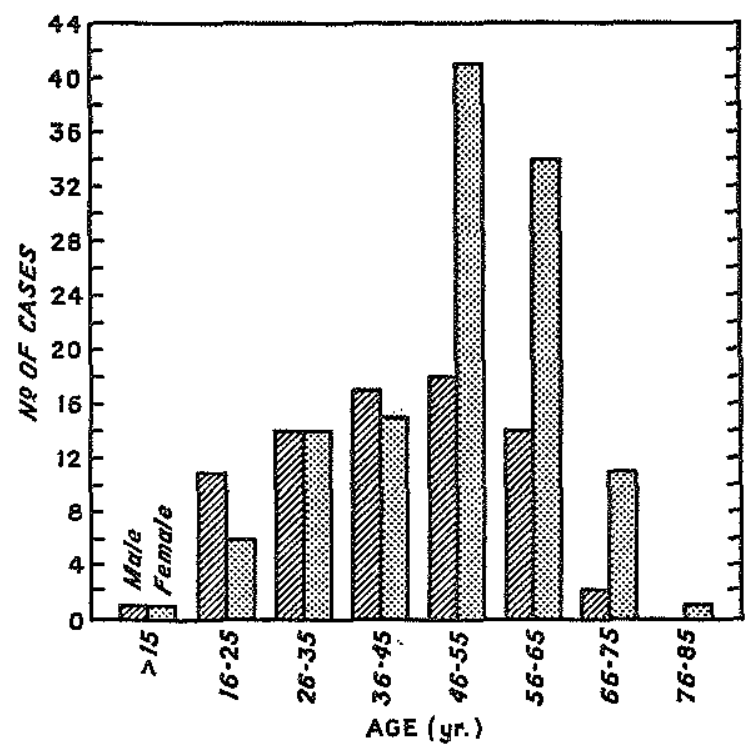

Fig. 2. Histogram showing the distribution of hyperparathyroidism according to age and sex (with the publisher's permission, from The Lancet nr. I: 449-450, 1969). 
upper limit in 80 year old men to lie $0.4 \mathrm{mg} / 100 \mathrm{ml}$ lower than that for 20 year old males. Since these data were not known to us at the time, it remains possible that we missed the diagnosis more often in older men than in older women.

Our 255 cases of proven primary hyperparathyroidism included 160 women and 95 men (62.8 and $37.2 \%$ respectively). This means a ratio of $1.68: 1$. The age distribution for both sexes is given in Fig. 3 ; no correction for the composition of the population was applied here.

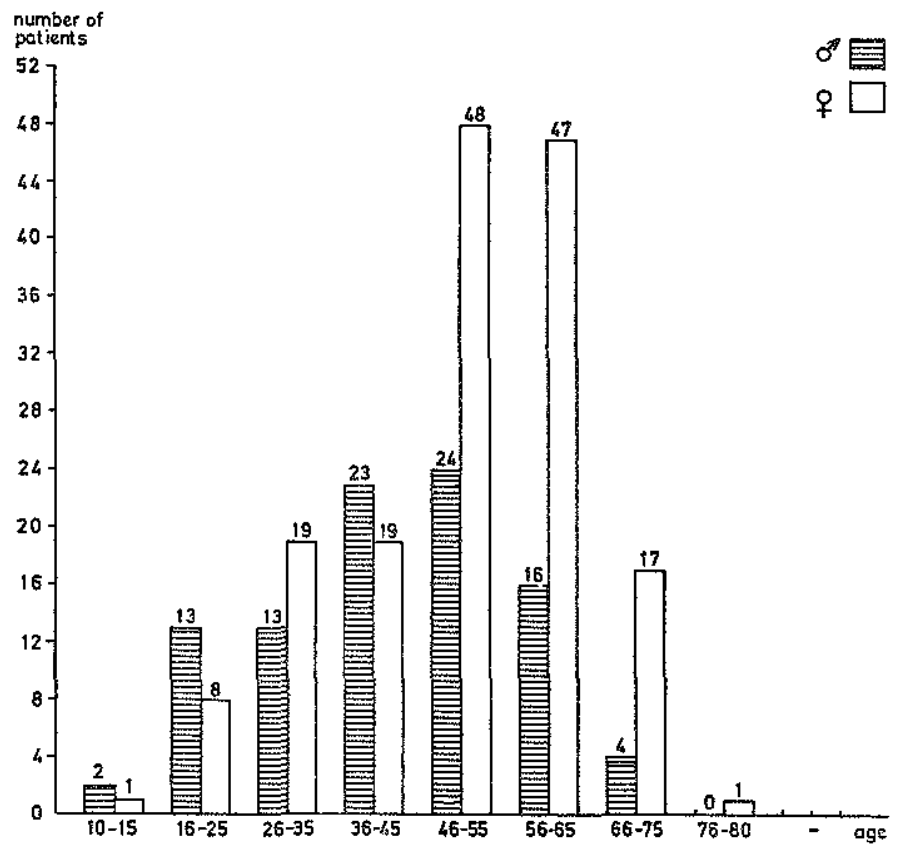

Fig. 3. Age distribution of 255 primary hyperparathyroidism patients, according to sex.

Here too the virtually symmetrical curve for the males is striking, the females giving rise to an asymmetrical curve with a sharp peak after the age of 45. Below this age, the incidence is almost the same for both sexes ( 47 women, $51 \mathrm{men}$ ); above it, the incidence is 2.5 times higher in women.

To reach a conclusion concerning a possible pathophysiological relationship between age, sex, and the etiology of primary hyperparathyroidism, it is recommendable that a curve of this kind be constructed, using the estimated age at which the disease began. These data for the present material are being analysed and will be given in the thesis mentioned above (see Introduction). 


\section{Chapter VIII - The surgical technique}

The golden opportunity to find a small parathyroid adenoma lies in the first surgical exploration of the neck.

Churchill and Cope (1934)

When the surgeon is convinced that primary hyperparathyroidism has been correctly diagnosed, surgery is the treatment of choice. Technically, the operation offers two main problems; first, to find the glands; and second, how many and which glands should be resected. In order to arrive at the most logical form of operation on the basis of present knowledge of parathyroid tumors, these two points must be analysed.

In addition, it is of paramount importance to succeed with the first operation, not only to spare the patient a second procedure and to put an end to the progressive kidney damage but also because re-exploration means that dissection must be done in tough connective tissue containing many lymph glands, which appreciably complicates the second operation. Under these conditions the surgical field is more difficult to survey and the chance of camouflage by minor hemorrhages is increased. Furthermore, lesions of the recurrent laryngeal nerve are more likely to occur at re-exploration (Baehrs \& Vandertoll 1963). It must also be kept in mind that since the enlarged parathyroids were missed at the first exploration, there is a greater chance that an abnormal localization is involved.

\section{Finding the glands}

The operation is performed under intratracheal anesthesia. The head is fixed in a position with slight extension of the neck. The use of a pillow under the shoulders is not recommendable: little is gained with respect to the field of vision, and the patient may have severe complaints for many months due to the hyperextension of the neck during what is sometimes a very long operation. After a transverse collar incision has been made, the skin flaps are mobilized proximally and distally over a considerable distance. Next, the superficial fascia and platysma are divided. The sternohyoid, omohyoid, and sternothyroid muscles are divided and dissected from the thyroid gland. 
It can be difficult to find normally situated parathyroid glands, because they may be hidden in or behind fat lobules or connective tissue behind the thyroid gland. To obtain a good view of the entire space behind the thyroid gland, the entire gland must be adequately mobilized. If present, the middle thyroid vein must be divided (Hellner 1965), after which the inferior thyroid artery must be found and ligated.

The most frequent complication accompanying operations in this region is paralysis of the vocal cords. To prevent this, the last step before starting the exploration proper is to locate and dissect free the recurrent laryngeal nerve in the region of the larynx and the upper part of the trachea. This step is also useful for finding the parathyroids (see page 9).

This is the point at which the search for both the normal and enlarged parathyroids begins (Muller, personal communication). The lobe of the thyroid is turned over to the other side by pulling with a tissue forceps. The parathyroids can be distinguished by their slightly darker yellowish-brown color and finely granular appearance as compared to the fat tissue. They are attached to the thyroid gland, but are further independently mobile. If blood appears in the surgical field, the surrounding tissue acquires the same darker color as the parathyroids, thus camouflaging them. Consequently, it is imperative to dissect carefully, without causing any bleeding or excising any tissue unnecessarily. For this, time and patience are indispensable (Black 1963, Cope 1964, Davies 1966).

To keep the surgical field as free of blood as possible, an artificial reduction of the systolic blood pressure to $80-90 \mathrm{~mm} \mathrm{Hg}$ can be induced by infusion of trimethanecamphorsulfonate (Arfonad ${ }^{R}$ ) when no contraindications to this are present (myocardial or cerebral ischemia). In our series its application did not lead to any complications in the sense of a cerebrovascular accident, myocardial infarction, or kidney damage, even in cases with prior hypertension. This artificial reduction of the blood pressure is of great value in re-exploration: the presence of marked fibrosis in the neck region can result in so much oozing of blood in the surgical field that dissection may be virtually impossible unless hypotension is applied.

The upper parathyroids are sought first in the normal localization and then the lower glands, the entire posterior surface of the thyroid being inspected. When they are not found there, inspection and palpation of the thyroid may even in this stage lead to suspicion of an intra-thyroidal tumor.

Next comes exploration around the trachea and esophagus and in the prevertebral space, in the cranial, caudal, and lateral directions. Lastly, the carotid sheath is opened and inspected.

The procedure is of course terminated as soon as the upper and lower 
parathyroids have been found. The glands are then very carefully dissected free of the surroundings so that their size can be judged. This care is imperative because the vascularization via the hilus is often difficult to distinguish. A small biopsy sample is taken, as far as possible from the hilus, from all structures that might be parathyroids, and immediately examined in frozen sections. Enlarged glands are not excised at this time. First, the same procedure is carried out on the other side. Lastly, even if four glands have been identified, with confirmation from frozen sections, the thymus is inspected and in adults usually excised, because it may contain normal or enlarged supernumerary parathyroids. At the same time, the field must be examined for abnormal vessels running in the caudal direction.

The surgical approach to mediastinal tumors with a possibly intra-thymic localization can be made in two ways, either from the cervical incision or by means of a sternotomy. Via the cervical incision and with blunt dissection behind the manubrium sterni, both thymus glands are brought forward and upward, inspected, and if necessary excised (Black 1952, Hellström \& Ivemark 1962, Adams \& Murphy 1963, Higgins 1964, Albo \& Stevens 1968, Nathaniëls et al. 1970). It is our experience that with this approach the retrosternal space can usually be surveyed up to the level of the innominate artery. With this method, up to $95 \%$ of all mediastinal tumors can be excised. For more caudally localized tumors, sternotomy is required in 1.7 to $5 \%$ of the cases (Black 1963, Hellström 1965, Davies 1966, Nathaniëls et al. 1970).

Since recovery from hyperparathyroidism after a negative neck exploration has been described several times (probably being due to accidental destruction of the vascular supply of the tumor), there is no agreement in the literature whether, after a negative neck exploration, a sternotomy must be performed immediately during the same operation. Some authors do this, others wait for 6 to 12 weeks to see whether a spontaneous improvement occurs. If it does not, a sternotomy is performed in a second operation. In our experience a sternotomy is very rarely necessary: As will be mentioned (page 63) even very deep-lying intrathymic parathyroids can be removed via the cervical incision. Extrathymically localized retrosternal parathyroid glands rarely occur.

Only when there is a clear-cut indication for a mediastinal tumor (e.g. by the presence of an abnormal vessel or a suspicious shadow on the thoracic radiogram or tomogram of the mediastinum) or when at re-exploration the amount of fibrosis is so great that exploration via the cervical incision is too dangerous, is a sternotomy performed at the same operation. For this operation the sternum is usually divided longitudinally as far as the third intercostal space. 
If the sternotomy is to be performed in a separate procedure, we have found it better to postpone this operation for at least three months when there is no compelling reason to operate as soon as possible. If the operation is done sooner, the tissue reaction and fibrosis in the neck make good anatomical exploration extremely difficult and it is imperative that all the structures in the neck be dissected again.

Of the abnormal localizations in which both the upper and the lower parathyroids can be found, the intra-thyroidal is by far the most important after the retrosternal. The former localization is found in 1 to $7 \%$ of the patients (Norris 1947, Black 1952, Hellström \& Ivemark 1962, Higgins 1964, Marks 1968, Goodman et al. 1969). Like the mediastinal localization, the intra-thyroidal should be suspected whenever a gland cannot be found. The suspicion is strengthened when a lobe of the thyroid gland shows local discoloration or enlargement and when a lump is found at palpation. In that case the tumor can be removed via an incision through the thyroid capsule (thyroidotomy). Sometimes, thyroidotomy makes better palpation possible. We prefer the following procedure. The thyroid arteries are temporarily ligated and an incision is made on the anterior surface of the lower lobe. At this stage we have had the experience several times that the enlarged parathyroid literally popped out of the thyroid. Finally, if a gland remains unfound, a 'blind' unilateral resection of the upper or lower lobe of the thyroid can be performed (Black 1963, Coffey et al. 1965). When two out of four glands are still missing, a bilateral upper or lower lobe resection can be performed or a hemithyroidectomy (Black 1952, Hellström \& Ivemark 1962, Pyrah et al. 1966, Goodman et al. 1969).

We consider total thyroidectomy, as advocated by a few authors for an elusive tumor, to be a technical error.

\section{The resection}

Second only to the problem of finding the parathyroids, the greatest problem in parathyroid surgery is the question of how many of these glands should be removed. If primary hyperplasia did not have to be taken into account, the solution would be simple: the enlarged glands (adenomas) could be resected, the normal glands left undisturbed. But the discovery of primary hyperplasia by Cope et al. in 1958 was not only important with respect to the pathogenesis of the disease. The realization that it is imperative that all the parathyroids must be found at exploration led to the finding of more tumors in each patient and therefore to a smaller percentage of failures. A steadily increasing number of investigators are of the opinion that in 
primary hyperparathyroidism, primary hyperplasia is originally present, so that all the glands are potentially affected. The consequence of this is that in principle a subtotal parathyroidectomy (resection of $3 \frac{1}{2}$ glands) would have to be performed. Persistence or recurrence of the disease due to hyperfunction of the glands considered normal at the first operation would thus be prevented (Cope 1966, Muller et al. 1966, Block et al. 1967, Utley \& Black 1967, Lloyd 1968, Graber \& Jacobs 1968, Rienhoff et al. 1968, Straus \& Paloyan 1969, Kramer 1970). But the reverse of the medal is that the consistent performance of subtotal parathyroidectomy brings with it the high risk of permanent post-operative hypoparathyroidism. This means lifelong treatment with dihydrotachysterol and possibly calcium, with frequent determination of the plasma [Ca]. But if the subtotal operation is not performed, there is the threat of recurrence. It is between this Scylla and Charibdis that the surgeon is forced to navigate without a compass. For the present, at least, pre-operative prediction of the pathological substrate remains impossible.

A prospective double-blind study has not yet been performed to investigate the value of subtotal parathyroidectomy. Paloyan et al. (1969) compared the results obtained since 1965 in 26 patients in whom subtotal parathyroidectomy had been performed for suspected primary hyperplasia with the results obtained before 1965 in 27 patients in whom only enlarged parathyroids had been removed. With the radical treatment the number of recurrences dropped from $15 \%$ (4 patients) to nil. Remarkably enough, post-operative persistent hypoparathyroidism also dropped: from 19\% to $8 \%$. These results must be interpreted with a certain amount of reserve. For one thing, the interval between the first operation and the diagnosis of the recurrence is not mentioned. This makes the differentiation between true recurrences and latent failures due to the missing of enlarged glands impossible. The improvement of the results in what is actually a small series could furthermore be at least partially due to the accumulation of experience. The group of pre-1965 patients were operated on by different surgeons, most of the post-1965 group by the same one. The improvement in the results could even be explained solely on the basis of the fact that after 1965 every attempt was made to expose all the glands and to take biopsy samples.

Our own approach is the following. After attempting to expose all four parathyroids, biopsy samples are taken from them. When the pathologist confirms the diagnosis parathyroid tissue, the situation is re-evaluated and a plan is made for the resection, the objective being to reduce the amount of parathyroid tissue to the quantitatively (and preferably qualitatively as 
well) normal amount of tissue (100-150 mg). As has already been argued, we do not base this consideration on the histological picture shown by the frozen section. Abnormally large glands are taken as pathological. Grossly normal-appearing glands are left undisturbed (Muller et al. 1966). The decision as to which glands must be removed now has two aspects: one with respect to cases in which there is a normal gland or glands, the other applying to cases in which no normal parathyroids are present.

\section{Tumors in combination with normal glands.}

When the surgeon is convinced that good vascularization of the normal parathyroid tissue is assured, there is no difficulty. The enlarged glands are resected. If the vitality of the sole remaining normal gland is not certain (as may occur when three tumors are found), a small part $(50 \mathrm{mg}$ ) of the gland with the most distinctly healthy and undamaged vascular pedicle can be left behind.

\section{All exposed glands are enlarged}

When all four glands are enlarged, a subtotal resection must be performed and part of the least enlarged gland is left behind ( $100 \mathrm{mg}$ ). If the vitality is dubious or this gland would be difficult to find again at a possible later exploration, part of another gland can be left behind instead. (For the same reason, in divergence from our principle, we occasionally excise an abnormally localized, apparently healthy gland to avoid difficulties in case of a later recurrence).

The situation becomes much more complicated when one or two enlarged glands are found at exploration but the others cannot be located. In our material this occurred in four patients not previously explored. Our experience was then still rather limited, since these four patients were among the first few of the series. It is difficult to form an opinion about unexposed glands. It can only be said that the more thorough the exploration the less the chance that such glands have remained undamaged. For this reason we do not advocate blind excision of all the fibro-areolar tissue behind the thyroid gland. This practice increases the chance of removing a normal gland where careful exploration would certainly have revealed an enlarged gland if present.

The situation in which only enlarged glands are found is often encountered when an exploration or thyroidectomy has been done previously. It is of course of paramount importance to know whether, and if so which, para- 
thyroid(s) were removed at that time. Unless the previous surgical report and histological data are available, a re-exploration is unnecessarily difficult and dangerous. In the absence of detailed information and when only tumors are found at exploration, it is safest to assume, after a thorough search, that any missing glands must have been previously removed. In these cases, therefore, a subtotal resection of the exposed tumors should be performed. We wish to emphasize once again that a re-exploration - whether performed because of recurrence or failure - will proceed much more smoothly if the surgeon has been able to obtain complete information about the previous surgical findings. It is therefore imperative that the surgical report include an accurate drawing of the situation encountered with indication of the removed glands (Muller et al. 1966). In some cases it may be wise to place metal clips next to the glands left in situ, in case of recurrence (Feind 1964, Adams et al. 1965, Block et al. 1967, Black \& Utley 1968, Graber \& Jacobs 1968, Rienhoff et al. 1968). This holds especially for marking remnants of subtotally removed tumors. 


\section{Chapter IX - Analysis of the findings in 267 patients}

Of the 267 patients whose clinical histories were studied, a few were not suitable for detailed analysis. One of these patients was operated on to confirm the diagnosis essential hypercalcuria, because he was a young man and the kidney function was already so poor that several parameters could not be used. At operation, four normal parathyroid glands were found. In another patient, a woman with a severe renal disease and secondary parathyroid hyperplasia, a subtotal resection was performed to relieve insupportable itching. A third patient underwent subtotal resection for a secondary hyperparathyroidism which had become autonomous (i.e. tertiary hyperparathyroidism) after a successful kidney transplantation.

Four patients underwent an exploration on erroneous grounds. One of these had a pseudo-hyperparathyroidism with all the phenomena of primary hyperparathyroidism, due to carcinoma in a kidney that had not functioned for the past ten years. The other three had sarcoidosis with hypercalcemia, which had not been diagnosed despite thorough investigation. The diagnosis could only be made on the basis of histological investigation of the lymph glands found along the trachea during exploration. In all four patients four normal parathyroid glands were found and in one case the diagnosis sarcoidosis was made on the basis of the biopsy sample of one of the parathyroids.

Lastly, the exploration failed in 5 patients, mainly because of the very marked fibrosis in the neck as the result of earlier exploration(s) done elsewhere. From the clinical data we must assume that they were indeed suffering from a primary hyperparathyroidism (see Table III).

In two referred patients with persistent hypercalcemia after the removal of one or more enlarged parathyroids, no tumor was found at our re-exploration The operation had to be terminated prematurely due to complications. These last two patients will be discussed in connection with the series of patients with proven hyperparathyroidism. 
Table III. The material of the present study.

\begin{tabular}{|c|c|c|c|c|}
\hline & $\begin{array}{l}\text { No. of } \\
\text { patients }\end{array}$ & $\%$ & $\begin{array}{l}\text { No, of } \\
\text { patients }\end{array}$ & $\%$ \\
\hline $\begin{array}{l}\text { Our own patients } \\
\text { Referred patients }\end{array}$ & & & 236 & 88.4 \\
\hline $\begin{array}{l}\text { Explored once elsewhere } \\
\text { Explored twice elsewhere }\end{array}$ & $\begin{array}{r}26 \\
5\end{array}$ & $\begin{array}{l}9.7 \\
1.9\end{array}$ & 31 & 11.6 \\
\hline Total number of patients & & & 267 & 100.0 \\
\hline
\end{tabular}

As already mentioned, the clinical and biochemical diagnosis of our patients will not be considered here because they are the subject of a separate study. Here, it need only be mentioned that with increasing experience, exploration was decided upon sooner and more easily, even when according to the out-moded criteria the hypercalcemia would be called slight.

Table IV. Principal signs and symptoms in 255 patients with hyperparathyroidism.*

\begin{tabular}{lc}
\hline Sign/Symptom & No. of patients \\
\hline Urolithiasis & 150 \\
Pyuria & 6 \\
Hypertension & 4 \\
Bone pain or pathology & 20 \\
Peptic ulcer & 21 \\
Stomach pain & 4 \\
Anorexia & 10 \\
Nausea & 25 \\
Vomiting & 26 \\
Constipation & 15 \\
Thirst & 10 \\
Polyuria & 11 \\
Fatigue & 37 \\
Depression & 1 \\
Psychosis & 2 \\
Pre-coma & 1 \\
Coma & 1 \\
\hline Accidental finding & 20 \\
Family investigation & 2 \\
\hline
\end{tabular}

* The total number is higher than 255 because many of the patients had more than one. 
In the majority of the cases, as could be expected, the signs leading to suspicion of hyperparathyroidism was kidney stones, but also an unexplained pyuria or epididymitis. The remaining indications represent the entire scale of the already mentioned 'bones. .., stones. .., abdominal groans. . and fatigue overtones' (see Table IV).

It is striking to note that in about $8 \%$ of the patients the diagnosis was made by chance.

There were 255 patients in whom the diagnosis primary hyperparathyroidism could be made with certainty (see page 59). The youngest patient was 10 years old, the oldest 79 . The men numbered 95 and the women 160 . For the distribution according to age and sex, see Fig. 3 (page 41).

Initially, the number of patients treated annually was small, but after 1961 there was a marked increase (see Table V).

Table V. Distribution of operations for hyperparathyroidism over 5-year intervals from 1950 to 1970 .

\begin{tabular}{cc}
\hline Period & No. of patients \\
\hline $1950-1954$ & 12 \\
$1955-1959$ & 25 \\
$1960-1964$ & 65 \\
$1965-1969$ & 165 \\
\hline Total & 267 \\
\hline
\end{tabular}

In the following pages the surgical findings will be discussed, including the total number of parathyroids found, the localization of normal and abnormal parathyroids, the technique of the resection, the complications arising during surgery, the mortality, and the late results.

\$1. LOCALIZATION OF THE PARATHYROID GLANDS IN 267 PATIENTS

In the following, the term tumor is used in the purely Latin sense of a swelling, with no pathological differentiation implied.

As already mentioned (see page 7), the localizations of 939 glands were available for analysis. Of these, $235(25 \%)$ lay outside the previously described normal area, 86 of them against the posterior surface of the thyroid 
gland or rather close to the lower pole of the thyroid gland. At exploration this localization gave little or no difficulty, and these glands are therefore classified as subnormal (see Table VI).

Table VI. Localizations of 939 parathyroid glands as found at operation.

\begin{tabular}{lcc}
\hline Localization & No. of glands & $\%$ \\
\hline Normal & 704 & 75.0 \\
Subnormal & 86 & 9.2 \\
Abnormal & 149 & 15.8 \\
\hline Total & 939 & 100.0 \\
\hline
\end{tabular}

This leaves 149 highly unusual localizations whose distribution is shown in Table VII.

Table VII. Abnormal localization of parathyroid glands in our material.

\begin{tabular}{lcr}
\hline \multicolumn{1}{c}{ Localization } & No. of glands & $\%$ \\
\hline Intra-thymic & 79 & 53.0 \\
Anterior mediastinum & 23 & 15.4 \\
Posterior mediastinum & 19 & 12.8 \\
Retro-thyroidal & 10 & 6.7 \\
Intra-thyroidal & 17 & 11.4 \\
Ante-thyroidal & 1 & 0.7 \\
\hline Total & 149 & 100.0 \\
\hline
\end{tabular}

Table VII shows that the number of retrosternally located glands (i.e. in the thymus and mediastinum) amounts to $79+23+19=121$, which is $81.2 \%$ of the total number of abnormally located glands and $12.9 \%$ of the total number of glands found. These 121 glands were found in 104 of our 267 patients. Twelve of them had been referred to us after the failure of an exploration elsewhere, so that (in this respect aselectively) in $\frac{104-12}{267-12} \times$ $100=36.0 \%$ of the patients a mediastinally located gland was found. A percentage as high as this is not mentioned anywhere in the literature, and we shall therefore describe these findings in some detail. 
Intra-thymic localization: Because of the local anatomical relationships, intrathymic glands always lie retrosternally in the anterior mediastinum. The level at which they lie can be indicated: we call glands situated $0-2 \mathrm{~cm}$ under the upper edge of the sternal manubrium 'high intra-thymic'; those located $2-4 \mathrm{~cm}$ lower are in an intermediate position; and those lying more than $4 \mathrm{~cm}$ under the upper edge of the sternal manubrium are situated 'low' in the thymus (see Table VIII).

Table VIII. Intra-thymic localization of parathyroid glands.

\begin{tabular}{lclc}
\hline \multicolumn{1}{c}{ Side } & $\begin{array}{c}\text { No. of } \\
\text { patients }\end{array}$ & Situation & $\begin{array}{c}\text { No. of } \\
\text { glands }\end{array}$ \\
\hline Right & 20 & High & 46 \\
Left & 25 & Intermediate & 20 \\
Bilateral & 17 & Low & 13 \\
\hline Total & 62 & & 79 \\
\hline
\end{tabular}

Table VIII shows that abnormal locations occurred almost as often on the left as on the right side. Of the 79 glands, 27 were normal and 52 enlarged. Four of the glands were found in patients who had already undergone exploration elsewhere. Thus, in at least $\frac{62-4}{267-4} \times 100=22.1 \%$ of the patients an intra-thymic location in the thymus was found aselectively. This percentage too is higher than any of those given in the literature.

It can also be seen from Table VIII that the glands are not usually situated low in the thymus. Nevertheless, the possibility of a low intrathymic situation must be kept in mind and, if possible, the entire thymus should be dissected free to obtain certainty that a tumor is not left behind in the lower pole.

In 12 patients in our series in whom we found more than 2 glands on one side, 5 of the surplus glands lay in the thymus. The intra-thymic glands are always lower parathyroids. However, we have seen three cases of an anatomical variant in which an upper parathyroid gland was surrounded by ectopic thymus tissue.

Mediastinal localizations outside the thymus: All the glands we found outside the thymus in the mediastinum were enlarged. This holds for both the anterior and the posterior mediastinum. For these tumors, Table IX shows 
the distance from the tumor to the upper edge of the sternum. We have already pointed out (page 10) that it may depend on the degree of extension of the neck whether or not the localization is retrosternal. The localizations given in Table IX represent the surgical findings made with the head fixed in slight extension.

It seems to us important to indicate here too the level at which these glands were found, the more so because the depth of the localization is determinative for the recognition and the mode of excision. Tumors whose midpoint or upper margin reaches to the sternal notch are of course easily found through the cervical incision. From the anatomical standpoint, their situation is mediastinal. Tumors with a completely retrosternal position but located less than $5 \mathrm{~cm}$ from the sternal notch can be found during the exploration of the thymus. When the position is still more caudal (which corresponds roughly to the level of the innominate artery), this is not possible.

Table IX. Localization of mediastinal tumors in the present series.

\begin{tabular}{|c|c|c|}
\hline \multirow[b]{2}{*}{ Localization } & \multicolumn{2}{|c|}{ No. of tumors } \\
\hline & $\begin{array}{c}\text { anterior } \\
\text { mediastinum }\end{array}$ & $\begin{array}{c}\text { posterior } \\
\text { mediastinum }\end{array}$ \\
\hline Midpoint of tumor on sternal notch & 10 & 11 \\
\hline Upper edge on sternal notch & 7 & 5 \\
\hline Less than $5 \mathrm{~cm}$ under sternal notch & 3 & 3 \\
\hline More than $5 \mathrm{~cm}$ under sternal notch & 3 & 0 \\
\hline Total & 23 & 19 \\
\hline
\end{tabular}

The glands found in the posterior mediastinum were always upper parathyroids; 16 were located on the right side, 3 on the left. Glands in the anterior mediastinum were always (like the intra-thymic glands) lower parathyroids: 12 on the right, 11 on the left. In our patients no normal glands were found in the mediastinum outside the thymus. Eight of these patients were re-explored by us after failures elsewhere: 5 cases concerned a tumor lying at the level of the sternal notch, in 2 it lay entirely retrosternally less than $5 \mathrm{~cm}$ from the upper edge of the sternum, and in 1 case the tumor lay more than $5 \mathrm{~cm}$ below the sternal notch. Aselectively, thus, in $\frac{42-8}{255-8} \times 100$ 
$=13.8 \%$ of the patients a tumor with a mediastinal location outside the thymus was found.

Abnormal localizations in an extreme dorsal position: When such glands are normal and thus have small dimensions, they are sometimes difficult to find. When the possibility of this abnormal localization is kept in mind, however, tumors are only hard to locate at re-explorations hampered by heavy reactive formation of connective tissue.

Table X. Abnormal, extreme dorsal situation of parathyroids in the present material.

Localization

Against the trachea

Between trachea and esophagus

Against the esophagus

Behind the esophagus
No. and type of gland

2, both normal

2 , one normal, one tumor

3 , all tumors

3 , all tumors

Total

10, 3 normal, 7 tumors

Nine of these glands were upper parathyroids; 4 lay on the right and 5 on the left. One paratracheally situated gland arose from the lower left parathyroid.

Intra-thyroidal localizations: In 7 cases we found a tumor lying partially within and partially outside the capsule of the thyroid gland. For such glands, which like icebergs are partially concealed, care must be taken not to underestimate the size.

In 9 patients we found 10 glands entirely within the capsule; one of these cases concerned bilateral glands, the one on right being normal, the one on the left enlarged. This patient had been referred for re-exploration. In another patient a normal gland was found within the right lower lobe surrounded by thyroid gland follicles.

Thus, a total of 15 tumors and 2 normal parathyroids were found in the thyroid gland; there was no preferred localization.

Aselectively, in $\frac{15-1}{255-1} \times 100=5.5 \%$ of the cases a completely or partially intra-thyroidal tumor was found. 
Ante-thyroidal localization: This localization was seen only once in our material. The tumor lay on the anterior surface of the thyroid gland behind the sternothyroid muscle. Judged from the vascularization, this tumor had arisen from the lower right, but normal glands were also seen on the upper and lower right, which means that in this case there was not only an abnormal localization but also doubling of the gland.

\section{§2. ANALYSIS OF THE TECHNTCAL RESULTS}

An exploration for hyperparathyroidism can only succeed when the diagnosis is correct and all the parathyroids are found. The latter is dependent on the localization of the tumors and on whether an unsuccessful exploration has already taken place, since, as mentioned above, thiss everely hampers re-exploration.

For the composition of our patient material, see Table III (page 41).

\section{The present material}

For the group of 236 patients seen first by us, the first exploration was successful in 223 cases. In 6 patients a cure could only be achieved by reexploration required because the tumors could not be found in their abnormal situation at the first exploration (see Table XI). These failures belonged to the early part of the series, i.e. among the first 71 patients. With the accumulation of experience this no longer occurred, the more so because the lesson we drew from these failures led to improvement of the surgical technique. Of these 6 tumors, 3 lay intra-thymically, 2 retro-sternally, and one partially intra-thyroidally.

Table XI. Surgical results in our own patients.

\begin{tabular}{lcccc}
\hline Result & no. of cases & $\%$ & no. of cases & $\%$ \\
\hline $\begin{array}{c}\text { Normocalcemia - after 1st expl. } \\
\text { after re-expl. }\end{array}$ & 223 & 94.6 & 229 & 97.1 \\
$\begin{array}{l}\text { Persisting hypercalcemia, des- } \\
\text { pite removal of 4 or 5 tumors }\end{array}$ & 6 & 2.5 & & \\
$\begin{array}{l}\text { No enlarged parathyroids found } \\
\text { Exploration to confirm diagnosis } \\
\quad \text { of essential hypercalcuria }\end{array}$ & & & 0 & 0.8 \\
$\begin{array}{l}\text { Erroneous diagnosis } \\
\quad \begin{array}{l}\text { Pseudo-hyperparathyroidism } \\
\text { Sarcoidosis }\end{array}\end{array}$ & 1 & & 1 & 0.4 \\
\hline Total & 3 & & 4 & 1.7 \\
\hline
\end{tabular}


Thus, in the patients with a proven hyperparathyroidism, normocalcemia was achieved in 229 out of 231 , or $99.1 \%$. In the other two patients enlarged parathyroids were found and removed ( 4 in one case and 5 in the other) but a slight hypercalcemia persisted and we must assume that a 5th and 6th enlarged parathyroid gland had been missed.

\section{Discussion of the 5 patients in whom no hyperparathyroidism could be demon- strated.}

a. The patient was a 37 year old man with severe hypercalcuria and a severe kidney disease with uremia. Clinically, the diagnosis essential hypercalcuria seemed certain, but because of the severely impaired kidney function it was thought desirable to obtain absolute certainty by an exploration of the parathyroids. At the exploration in 1962, four normal parathyroids were found, so that the diagnosis idiopathic hypercalcuria could be confirmed. In his article entitled Vicissitudes of parathyroid surgery (1961), Cope gives an excellent discussion of these problematical cases.

b. A 57 year old female patient had the typical biochemical anomalies found in hyperparathyroidism. The function of the left kidney was entirely normal, and it was known that the right kidney had not functioned for 10 years; consequently, this was not further investigated. At neck dissection, no enlarged parathyroids were found, only 3 normal glands. A re-exploration was considered, but the patient rapidly developed symptoms of cerebral metastases and she died shortly thereafter of a primary carcinoma in the non-functioning kidney. It is known that renal cell carcinoma can produce a substance resembling parathyroid hormone, giving rise to pseudo-hyperparathyroidism.

c. In three cases hypercalcemia was caused by sarcoidosis that had not been recognized pre-operatively in spite of a thorough investigation of the internal organs. In one of these cases the Mantoux reaction was positive and the hypercalcemia did not respond to the administration of cortisone. The second patient had had a concomittant renal insufficiency, which complicated the diagnosis. In all three patients the diagnosis was suspected during the operation because of the presence of normal parathyroids and numerous pea-sized glands along the recurrent nerve. Histological examination of frozen sections of these lymph glands led to the correct diagnosis. In one of these patients a the typical sarcoid granuloma was found in the biopsy sample taken from one of the parathyroid glands (see also page 71).

In 2 patients the hypercalcemia persisted in spite of the removal of several enlarged parathyroid glands.

a. A 54 year old woman in whom a subtotal parathyroidectomy was performed because of enlargement of all four glands, continued to show hypercalcemia postoperatively. In this case there were probably more than four tumors, but the patient refused re-exploration. 
b. A 53 year old man had a plasma [Ca] of 14.7-15.5 mg/100 ml. At exploration 5 tumors were found, and a subtotal parathyroidectomy was performed. Postoperatively, the plasma [Ca] dropped only to $11.6-13-2 \mathrm{mg} / 100 \mathrm{ml}$. Further surgical treatment was not attempted. This probably concerned a case with 6 tumors.

\section{Re-explorations in patients previously operated on elsewhere}

In 24 of the 31 patients referred to us from other hospitals for re-exploration we were able to find the tumors (see Table XII).

Table XII. Results of 31 ve-explorations of patients previously exploved elsewhere.

\begin{tabular}{lcr}
\multicolumn{1}{c}{ Results } & No. of patients & $\%$ \\
\hline Successful - normal localization & 11 & 35 \\
Successful - abnormal localization & 13 & 42 \\
Failure & 5 & 23 \\
Failure (tumor already removed elsewhere) & 2 & \\
\hline Total & 31 & 100 \\
\hline
\end{tabular}

We made an attempt to determine what the reason could have been for the failure elsewhere to find the tumor. For the 11 patients in whom the tumors lay in the normal area, we assume that, in view of our findings, the thyroid gland had been insufficiently mobilized in one case, in 2 cases frozen sections had not been used, resulting in the removal of thyroid tissue; and in the other cases the tumor must simply have been missed.

In 13 patients an abnormal localization was involved: in 4 the tumor lay in the thymus, in 5 at the level of the edge of the sternal notch, in the posterior mediastinum. In 2 cases the tumors lay $2 \mathrm{~cm}$ and $3 \mathrm{~cm}$ from the sternal notch. In 1 , a sternotomy had to be performed because the tumor lay at the level of the pulmonary hilus. One patient had a partially intrathyroidal tumor.

In 7 patients we too failed to find a tumor. In 2 of these an enlarged parathyroid had been removed elsewhere but the hypercalcemia had persisted. Twice, the failure was due to a very tough fibrosis in the surgical field, which made the re-exploration impossible. One patient, in whom glands weighing 50, 80, and $100 \mathrm{mg}$ were excised and a normal gland was left in situ, developed cardiac arrest post-operatively, but external heart massage was successful. This patient remained hypercalcemic, but further surgery was not undertaken because of the cardiac condition. In 1 patient 
cardiac arrest occurred during the exploration. After re-animation, we refrained from further surgery. In the remaining 3 patients the anatomical relationships were so disturbed by previous operations (especially after total thyroidectomy) that no tumors could be found.

\section{§3. THE FINDINGSIN 255 PATIENTS WITH PROVEN PRIMARY HYPER- PARATHYROIDISM}

Among our own patients, at least one tumor (i.e. enlarged gland) was found in 229 cases. In 24 of the 31 patients who had undergone exploration elsewhere, the surgical results were also positive; a tumor had previously been removed in two of the other 7 cases. In total, these groups include 255 patients with a proven primary hyperparathyroidism.

\section{The origin of the tumors}

Figs. 4 and 5 give a schematic survey showing from which glands the tumors in our material originated. The often cited statement of Norris (1947) that $80 \%$ of the tumors originate in the lower right parathyroid gland, is certainly not correct. His conclusion is probably to be explained by the following. Explorations are almost always started on the right side. Formerly, operations were terminated after a tumor had been found, which made it inevitable that tumors on the right side would be found most frequently. The predominance of the lower gland may result from an erroneous observation: the tumors arising from the upper glands tend to descend caudally and may there for be taken for the lower glands. As can be seen from Fig. 4, in our material too solitary tumors were found more often on the lower right.

It is also clear from Figs. 4 and 5 that the origin of the tumors varies so widely that such data are irrelevant with respect to the surgical method. To insure success, all the glands must be exposed.

\section{The number of tumors}

Table XIII shows how many tumors were found per patient. The values between parentheses indicate the number of patients in whom only enlarged and no normal glands were found, possibly because the exploration was not sufficiently thorough or because at an earlier exploration or thyroidectomy parathyroid glands had been removed by mistake (see also Figs. 4 and 5). 


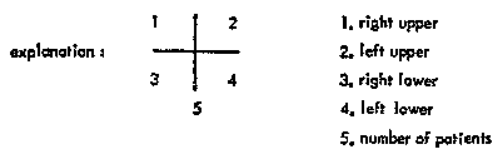

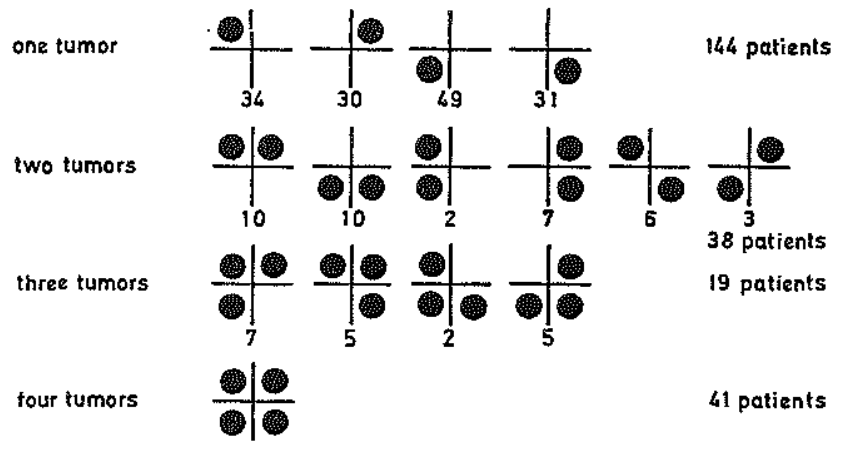

Fig. 4. Localization and number of tumors in 242 patients

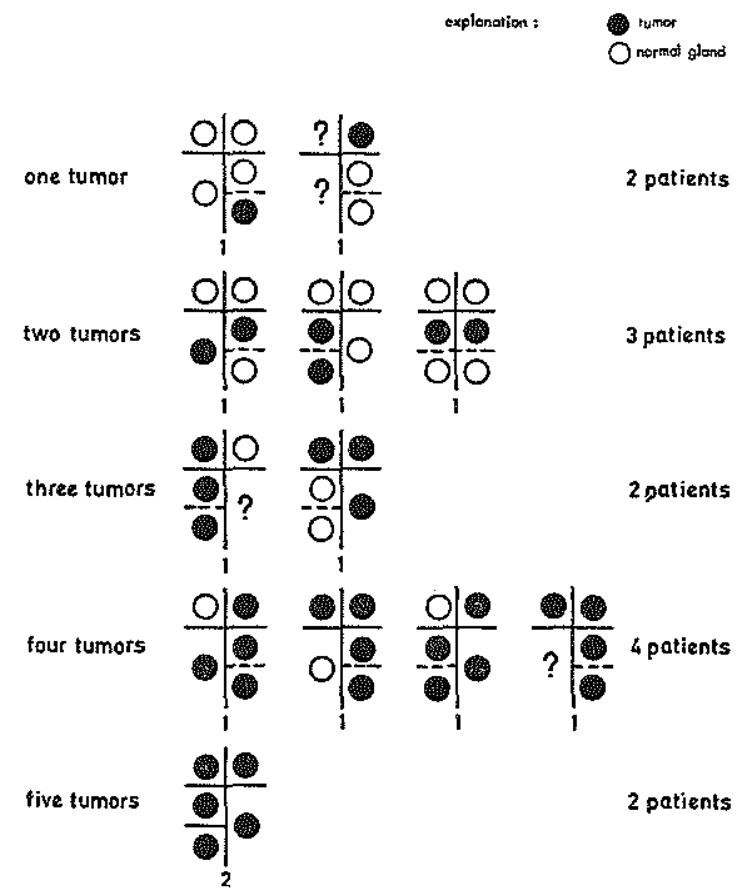

Fig. 5. Localization and number of tumors in 13 patients with more than two glands on one side 
Table XIII. The number of tumors per patient in our material.

\begin{tabular}{crrr}
\hline No. of tumors & No. of patients & $\%$ \\
\hline 1 & 146 & $(14)^{*}$ & 57.3 \\
2 & 41 & $(3)$ & 16.1 \\
3 & 21 & $(7)$ & 8.2 \\
4 & 45 & $(42)$ & 17.6 \\
5 & 2 & $(2)$ & 0.8 \\
\hline Total & 255 & $(68)$ & 100.0 \\
\hline
\end{tabular}

* Between parentheses: only enlarged glands found.

In 41 patients all 4 glands were found to be enlarged and in 2 all 5 , i.e. in $\frac{41+2}{255} \times 100=16.8 \%$ of the patients all the glands were certainly enlarged. It is theoretically possible that enlargement of all the glands was present in $\frac{68}{255} \times 100=26.6 \%$ of the patients.

To permit comparison of our findings with those of other authors, our data must be subdivided in another way. Cases in which we found two or three tumors would be called multiple adenoma by most other authors. For enlargement of all glands, comparison can be made with primary hyperplasia (see page 20).

Table XIV. Comparison of our numerical findings with the data in the literature.

\begin{tabular}{llll}
\hline \multicolumn{1}{c}{ Literature } & $\%$ & \multicolumn{1}{c}{ Our series } & $\%$ \\
\hline Solitary adenoma & $70-88$ & One tumor & 52.7 \\
Multiple adenoma & $0.1-6$ & More than one tumor & 23.5 \\
Primary hyperplasia & $11-25$ & All tumors & $16.8-(26.6)$
\end{tabular}

As has already been mentioned, in the literature the diagnosis multiple adenoma is reported less and less often and the diagnosis primary hyperplasia more and more often. The latter is confirmed by our findings. There is, however, considerable divergence between the number of multiple tumors, plus at least one gland of normal size, found by us and the reported number of multiple adenomata in the literature (see Table XIV). There are two 
possible reasons for this divergence. Firstly, we consistently tried to find all the parathyroids and therefore found more tumors. The second and in our opinion the most important reason, is that we took as sole basis the macroscopic appearance of the glands. We are therefore forced to conclude that not only the cases with enlargement of all glands observed by us but also those with enlargement of several glands plus at least one gland of normal size represent the picture called primary chief cell hyperplasia by others. Regarded in this way, our values show better agreement with those of Paloyan et al. (1969), i.e. $58 \%$ primary hyperplasias. Particularly the findings in 19 patients with three and four tumors plus one normal-sized gland support the view that in what is called primary chief cell hyperplasia all the glands do not per definition have to be enlarged.

The difficulties and limitations involved in the diagnosis normal or hyperplasia on the basis of the histological picture has already been discussed (see page $20 \mathrm{ff}$.).

The validity of our grounds for a practical approach, i.e. macroscopically normal $=$ functionally normal, and for the theoretical approach, i.e. macroscopically normal $=$ microscopically normal $=$ functionally normal, can in our opinion only be investigated at present on the basis of the number of recurrences of primary hyperparathyroidism developing in our patients in glands that had previously been macroscopically normal.

\section{§4. RESECTION OF THE TUMORS}

The excision of normally and subnormally situated glands generally did not give any difficulties. In two cases the tumor adhered to the recurrent laryngeal nerve but could be dissected free without damage to the nerve. In one case the tumor adhered to the posterior wall of the esophagus and even lay partially within the muscular layer.

Glands situated intra-thymically and those found less than $5 \mathrm{~cm}$ from the sternal notch could always be resected through the neck incision, although this sometimes required extra effort.

Sternotomy: This was necessary in three patients, in all of whom the tumor was situated below the level of the innominate artery: twice at the level of the pulmonary hilus, once near the origin of the aorta. Thus, the necessity for a sternotomy occurred in $\frac{3}{255}=1.2 \%$ of our patients.

For purposes of comparison, we wish to note that in the literature a mediastinal tumor is mentioned for at most $21 \%$ of the patients, at least 
$1.7 \%$ requiring a sternotomy. In our series these values are $36 \%$ and $1.2 \%$ respectively. In view of the high proportion of mediastinal tumors it is very obvious that retrosternal exploration through the cervical incision is an extremely valuable procedure in parathyroid surgery.

In 6 cases we performed a sternotomy without finding glands. In 5 of these patients the tumor was nevertheless found in the neck at a later stage. In one patient we failed to find a tumor either during the neck exploration or at sternotomy; post-operatively, the hypercalcemia persisted, so that this case must be considered one of our failures.

Intra-thyroidally situated glands: Fourteen of the tumors were found at inspection and palpation of the thyroid gland. After ligation of the inferior thyroid artery and incision of the capsule, they could be removed with ease. In one patient after a right hemithyroidectomy a normal gland was found in the resected specimen. In another patient a bilateral resection of the lower lobe was performed, the indication being absence of both lower parathyroids, a small multinodular thyroid (and therefore not easy to palpate), and a suspicious brown discoloration of the left lower pole for which the biopsy sample provided no information (no parathyroid tissue was present). Later investigation showed a normal parathyroid gland in the lower right part of the specimen and on the left, in the suspected area, an enlarged parathyroid was found. The biopsy had unfortunately been inadequate.

In 5 cases a hemithyroidectomy and in 1 case a subtotal thyroidectomy were performed without success.

From the foregoing the great value of inspection and palpation of the thyroid gland is clear. Intra-thyroidally situated tumors are relatively easy to locate. Normal glands cannot be found in this way, but their resection has no clinical value. In multinodular thyroids, thyroidotomy and possibly lobe resection must be considered indicated when intra-thyroidal tumors are suspected. 


\section{Chapter X - Post-operative course}

Of the 255 patients in whom parathyroid tumors were removed, $187(73.4 \%)$ could be followed over a period averaging $3 \frac{1}{2}$ years (see Fig. 6).

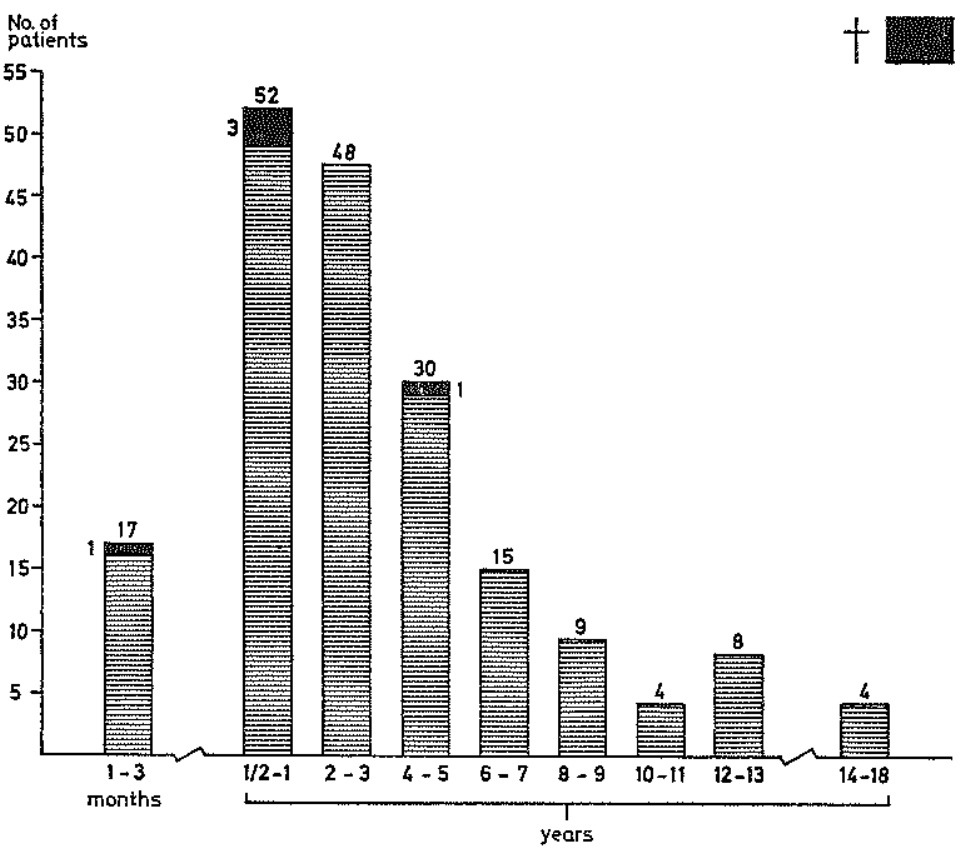

Fig. 6. Follow-up period after parathyroidectomy in the present series.

We consider a parathyroid exploration successful when the biochemical changes that are the direct result of the abnormally high plasma [PTH] are permanently normalized by the surgical treatment (albeit sometimes with a post-operative hypocalcemic phase due to calcium hunger of the 
bone). The results of the exploration in 260 patients in whom the diagnosis was confirmed clinically and biochemically, are shown in Table XV.

Table XV. Surgical results in 260 patients of the present series.

\begin{tabular}{lrr}
\hline & No. of patients & $\%$ \\
\hline Euparathyroidism & 240 & 92.4 \\
Hypercalcemia - no tumor found & 5 & 1.9 \\
Hypercalcemia - despite removal of tumor(s) & 6 & 2.3 \\
Possible recurrence* & 7 & 2.7 \\
Aparathyroidism* & 3 & 1.2 \\
\hline
\end{tabular}

* One patient became aparathyroitic due to re-exploration for a possible recurrence.

Thus, in 20 patients $(7.6 \%)$ the expected result was not reached, because of either inadequate or excessive resection. Cope (1960) considered resection to have been inadequate in $20 \%$ and Hellström and Ivemark (1962) in $18 \%$ of their patients. Experience led these authors to point out that improvement of the results occurs especially when all the glands are inspected at the operation.

That our results compare so favorably is to be attributed to the fact that almost from the beginning of the present series we have attempted to inspect all the parathyroids. The data and results of Davies (1966) run consistently parallel with ours. Comparison between our results and those of Black (1952, 1963 ) is impossible because of lack of data. Lastly, it may also be remarked that in our 20 cases of failure, improvement of the biochemical anomalies was nevertheless attained in 15 (i.e. reduction of the hypercalcemia, albeit not to normal values), because the amount of tumor tissue was reduced.

\section{Post-operative plasma [Ca]}

In all those patients in whom the exploration was successful, the plasma [Ca] dropped to the norm within 1 to 7 days (average 2 to 3 days). Fourty-four patients showed a transient hypocalcemia below $8.5 \mathrm{mg} / 100 \mathrm{ml}$ (Wade et al. 1965\%,b, Fourman et al. 1969), often accompanied by clinical phenomena such as paresthesia and Chvostek's sign. The severity of this hypocalcemia is also dependent on the degree of bone decalcification and elevation of the alkaline phosphatase level (Howard \& Thomas 1963) and 
the quantity of residual functional parathyroid tissue. Most of these patients were given calcium orally or parentally for some time and some received dihydrotachysterol orally.

In patients in whom the operation failed or the tumors were not found at the first exploration, the plasma [Ca] did not drop to normal values postoperatively in any of the cases.

These findings have led us to conclude that repeated determination of the plasma [Ca] during the first week after the operation gives a reliable, easily and rapidly obtainable impression of the surgical results.

\section{Complications}

As a direct result of the operation, the following complications occurred among 267 patients. In one patient the common carotid artery tore, for which a Teflon prosthesis was placed around the artery. In another patient a small tear in the thyrocervical artery was sutured. In one case a small hemorrhage occurred post-operatively.

Damage to the recurrent laryngeal nerve rarely occurred (ct. Baehrs \& Vander Toll 1963). We ascribe this to our rule that the nerve must be fully exposed before closer inspection is begun. Only one patient in this series has a permanent unilateral paralysis of the vocal cord. One other patient had a unilateral paresis for three months after the operation, but this patient had been intubated for 24 hours.

All the above-described complications occurred in patients in whom fibrosis and disturbance of the normal anatomical relationships obscured the surgical field, and all these patients had already undergone two explorations.

In two patients pneumothorax developed after sternotomy, but this never occurred after exploration of the mediastinum through the cervical incision, in contrast to the report of Nathaniëls et al. (1970).

Complications possibly related to hyperparathyroidism but probably not to the exploration itself, were encountered in two patients who later died. One of these patients probably died from a hypercalcemic crisis. One of the 31 patients referred to us for re-exploration died a month after an unsuccessful re-exploration for a possible recurrence of primary hyperparathyroidism. The cause of death was Zollinger-Ellison's syndrome, for which he had undergone several operations. One patient, who had already vomited on the day before the operation, developed an acute pancreatitis on the first post-operative day (confirmed by laparotomy). 
Other complications seen by us were 2 cases of an obstructive pneumonia and 5 cases of cardiac arhythmia, including 2 patients with cardiac arrest, both of whom were successfully re-animated. 


\section{Chapter XI - The prognosis of primary hyperparathyroidism}

\section{Mortality}

The final course of the disease is dependent on a combination of factors including the severity of the secondary damage and the degree of surgical success achieved, both of which are in turn dependent on the nature of the tumor (Lloyd 1968). The pre-operative condition of the kidneys is by far the most important factor with respect to the prognosis. Renal hypertension does not as a rule improve post-operatively, and is the most frequent cause of death in cases of late diagnosis. Hellström and Ivemark (1962) mention a mortality of $9 \%$ due to renal insufficienty after successful parathyroid operations. Poor kidney function improves post-operatively in about $10 \%$ of the cases (Hellström 1953, 1965). Nephrocalcinosis does not show regression, but after parathyroidectomy the frequency of recurrent urolithiasis decreases by about 70\% (Bradshaw et al. 1964, McGeown 1965). Gastrointestinal and mental disturbances may, if caused by hyperparathyroidism, show considerable improvement (Hellström \& Ivemark 1962, Goldsmith et al. 1966). Bone anomalies almost always show functional recovery, but remain radiologically demonstrable (Bartlett \& Cochran 1964). These aspects will not be gone into in detail here. We wish to mention, however, that only two of our patients succumbed to the effect of primary hyperparathyroidism. One of these patients died two days after the operation as the result of a hypercalcemic crisis.

This case concerned a 65 year old apathetic woman with a plasma [Ca] of 15.6-17.3 $\mathrm{mg} / 100 \mathrm{ml}$. and a urea clearance of $11 \%$. While in the hospital she became increasingIy somnolent and an emergency transfer was arranged for an exploratory operation. Six hours before the time scheduled for the operation, hypotension developed and she became comatous. The hypotension was corrected with noradrenalin. At surgery both enlarged upper parathyroids were removed. In view of the patient's condition a prolonged search for the lower glands was not made, but a tumor was not observed. Post-operatively, the plasma [Ca] dropped rapidly to $12.3 \mathrm{mg} / 100 \mathrm{ml}$. The patient vomitted old blood and became comatous again. She died 50 hours after the operation. Permission for an autopsy was not obtained.

This may certainly be considered to have been a case of a hypercalcemic crisis due to 'PTH intoxication', also called parathyroid crisis. 
Formerly, the mortality associated with this crisis was $20 \%$ when surgical treatment was applied and $100 \%$ when no operation was performed (Chodack et al. 1965; Wilson et al. 1964). At present it is known that these crises can often be avoided by forced hydration (MacLeod \& Holloway 1967, Mannix \& Loehr 1968). If the plasma [Ca] rises nevertheless or the symptoms increase in severity, a decrease in the plasma [Ca] must be induced by the infusion of phosphate (Goldsmith \& Ingbar 1966, Gardner \& Koppel 1969).

Our second patient died one year after the operation in a uremic condition due to poor kidney function, from which she had already suffered before the operation.

The low mortality in our series can only be ascribed to the fact that in our patients the diagnosis primary hyperparathyroidism had been made in an early stage by the urologists and internists to whom they had been referred. Three other patients in this series died of diseases not known to have any relationship with primary hyperparathyroidism: plasmocytoma, mammary carcinoma, and pulmonary emphysema with cor pulmonale (see Fig. 6).

\section{Recurrence}

As already mentioned, the study of recurrence of primary hyperparathyroidism is of paramount importance for an understanding of the pathogenesis of the disease and for the evaluation of our point of view concerning the removal of grossly normal glands. In the literature recurrences are mentioned only incidentally or as casuistic information; essential data about the course of the process are often omitted. We have already discussed the reports of Paloyan et al. (1969) (page 46).

The term 'recurrence' is often used in the literature - in our opinion incorrectly - for cases in which it is not clear whether there had been enlargement of glands previously observed to be normal or whether the operation had been only partially successful because not all the tumors had been removed. In the latter case we prefer to use the term false recurrence. In our opinion a true recurrence is involved only when the following criteria are satisfied. A successful operation is followed by a period of normocalcemia. Subsequently, there is a clinical and/or biochemical recurrence of hyperparathyroidism as a result of growth of the previously macroscopically normal gland(s) found and biopsied at an earlier exploration. Furthermore, indications of a prior secondary hyperparathyroidism must be absent (e.g. in osteomalacia or poor renal function). We will discuss the case histories of our patients with recurrences and attempt to differentiate between true and false recurrences. All of the 7 patients with recurrences belong to the 
group of 229 patients in whom the exploration was successful and who were referred to us without previous surgical treatment, i.e. there were $\frac{7}{229} \times 100$ $=3.1 \%$ recurrences.

1. A woman of 60 years (1955). Three enlarged parathyroid glands $(250,500$, and $600 \mathrm{mg}$ ), all showing almost exclusively chief cells, were removed. The fourth gland was grossly normal, but no biopsy samples were taken to confirm the diagnosis parathyroid tissue. The plasma [Ca] of 15.2 dropped to $10.9 \mathrm{mg} \%$ postoperatively.

In 1964, plasma [Ca] was $9.8 \mathrm{mg} \%$ with a hypercalcuria of $293-382 \mathrm{mg} / 24 \mathrm{hr}$ while the patient was on a Snapper diet; the creatinin clearance was $107 \mathrm{ml}$ per minute. In 1967 the plasma [Ca] was $11.2-13.0 \mathrm{mg} \%$; the patient complained of gastric pain. In 1968 plasma [Ca] of $10.5-10.7 \mathrm{mg} \%$ were found. No other data are available.

Since it is not certain that the fourth gland was normal and because the plasma [Ca] did not normalize post-operatively, we judge this to be a question of persisting hyperparathyroidism - albeit to a lower degree in other words a false recurrence. It is quite possible that the findings in 1964 were related to a normocalcemic primary hyperparathyroidism.

2. A woman of 39 years (1956). A tumor weighing $100 \mathrm{mg}$ and composed of waterclear cells was removed. Biopsy samples were taken from two other glands having a normal appearance; the fourth gland was not seen. Post-operatively, the plasma [Ca] dropped to $9.9 \mathrm{mg} \%$ and then rose within a week to $10.8 \mathrm{mg} \%$. From then until 1962, high-normal blood levels of calcium were found. In 1965 the plasma [Ca] was $11.7 \mathrm{mg} \%$ and plasma creatinine $0.83 \mathrm{mg} \%$. In 1970 there was a hypercalcemia of $11.0 \mathrm{mg} \%$.

On the basis of the post-operative rise of the plasma [Ca] above normal and the variable hypercalcemia after 1965 , we consider this to be a false recurrence.

3. A man of 32 years (1963). Two parathyroid tumors located at the lower poles of the thyroid gland and each weighing $300 \mathrm{mg}$ were removed; both were composed of water-clear cells. No other parathyroid glands were observed. Post-operatively, the plasma [Ca] dropped to $9.4 \mathrm{mg} \%$ and then rose spontaneously to $10.1 \mathrm{mg} \%$. In 1965 the patient had recurrent complaints of a gastric ulcer. The plasma [Ca] was $10.5-10.9 \mathrm{mg} \%$, the creatinine clearance was $111 \mathrm{ml} / \mathrm{min}$. The re-exploration showed that in 1963 not the lower but the upper parathyroids had been removed. The lower glands lay intra-thymically and were estimated to weigh 750 and 300 $\mathrm{mg}$. The larger tumor was totally resected, the smaller one subtotally. These 
tumors too were composed of water-clear cells. Post-operatively, a brief period of hypocalcemia was observed, for which $2 \mathrm{~g}$ calcium daily was given orally. Thereafter, the patient remained normocalcemic.

This case too did not satisfy the criteria justifying a diagnosis of true recurrence. Unfortunately, it is not known how long after the first operation hypercalcemia recurred. In any case, the interval between the two explorations was short (two years).

4. A woman of 47 years (1955). A tumor weighing $2,250 \mathrm{mg}$ and composed of chief cells was removed; the three other glands appeared normal and biopsy samples were taken. Normocalcemia developed post-operatively. In 1963, hypercalcemia (11.4-12.5 $\mathrm{mg} \%$ ) and a hypercalcuria (333 $\mathrm{mg} / 24 \mathrm{hr}$ ) were found. The creatinine clearance amounted to only $22-27 \mathrm{ml} / \mathrm{min}$. At re-exploration, both upper parathyroid glands were found to be enlarged (estimated weight $150 \mathrm{mg}$ ), and were totally resected. The remaining gland was not found. Post-operatively, the hypercalcemia persisted at the same level, and another re-exploration was performed. Pathological lymphomas were now found in the mediastinum, the histological picture being consistent with sarcoidosis. Normocalcemia could then be achieved with corticosteroid therapy, which was still applied with success in 1970.

This was certainly not a case of true recurrence. In view of the persisting hypercalcemia after the first re-exploration, we consider tertiary hyperparathyroidism to be excluded as well. The enlargement of the two glands seen at the second operation may have been the result of the bad kidney function. On the basis of the good response to corticosteroid therapy, the hypercalcemia must be ascribed to the sarcoidosis, which developed in a patient in whom a successful parathyroid exploration had been performed in the first instance (1955).

5. A woman of 59 years (1957). A tumor weighing $1,500 \mathrm{mg}$ and composed mainly of chief cells but also showing groups of water-clear cells, was removed; no other glands were found. Post-operatively, the plasma [Ca] dropped to $9.0 \mathrm{mg} \%$ and then rose during her stay in the hospital to $10.4 \mathrm{mg} \%$. In 1960 and 1961 these values were 10.8 and 10.4, respectively. In 1966 values of $10.8-11.2 \mathrm{mg} \%$ were found, in 1967 and $1970,11.1$ and $10.6 \mathrm{mg} \%$, respectively. Since the patient had no complaints and the kidney function was very good, further evaluation was omitted.

Here, too, we consider that a false recurrence was involved, because the calcium level was consistently rather high post-operatively and only one gland had been found at exploration. 
6. A woman of 54 years (1961). Two tumors composed of water-clear cells were removed, both weighing $400 \mathrm{mg}$. The lower parathyroids were not seen. Normocalcemia developed post-operatively and persisted until 1963. The next determination was not made until 1968, when the patient returned because of her old complaint, a duodenal ulcer. The plasma [Ca] was $12.4-13.6 \mathrm{mg} \%$ and kidney function was good, as prior to the first operation. At re-exploration the lower parathyroids were found bilaterally in the thymus and were removed. One was of normal size, the other weighed $800 \mathrm{mg}$ and was composed of water-clear cells. Post-operatively, a severe hypocalcemia developed due to the surgically acquired aparathyroidism. Substitution therapy with calcium and dihydrotachysterol led to normocalcemia in 1969.

In this case too, we do not consider that a true recurrence was demonstrated, because at the first operation only two glands had been seen.

7. A woman of 45 years (1960). Two parathyroids weighing 800 and $200 \mathrm{mg}$ and composed of chief and transitional water-clear cells were removed. The other two parathyroids were considered normal but not biopsied. Post-operatively, the plasma [Ca] dropped to $9.5 \mathrm{mg} \%$; in 1961, 1962, and 1963 the values were 10.4 , 10.5 , and $10.2 \mathrm{mg} \%$, respectively, the plasma $\left[\mathrm{PO}_{4}\right]$ varying from 2.0 tot $2.6 \mathrm{mg} \%$. In 1966 hypertension was found and a chlorthiazide preparation was administered, resulting in a hypercalcemia of $11.3 \mathrm{mg} \%$ and a plasma $\left[\mathrm{PO}_{4}\right]$ of $2.0 \mathrm{mg} \%$. After termination of this anti-hypertension therapy the plasma [Ca] was $10.5 \mathrm{mg} \%$, the plasma $\left[\mathrm{PO}_{4}\right] 1.9 \mathrm{mg} \%$. In 1970 a spontaneous, very slight hypercalcemia of $10.8-10.9 \mathrm{mg} \%$ and a plasma $\left[\mathrm{PO}_{4}\right]$ of $1.8-2.0 \mathrm{mg} \%$ were found. Clinical analysis showed a slight hypercalcuria $(179-204 \mathrm{mg} / 24 \mathrm{hr}$ ) with the patient on a Snapper diet. Radiologically, a slight decalcification of the bones of the skull was demonstrated. The histological results in a bone biopsy sample were consistent with hyperparathyroidism. The intravenous pyelogram showed a kidney stone not previously observed. The patient still has no complaints suggesting primary hyperparathyroidism. However, since a kidney stone had been demonstrated a re-exploration was undertaken in 1971. No tumor or normal glands could be found.

This last case is the only one in our series in which the possibility of the existence of a true recurrence cannot be denied. However, no biopsy samples were taken from the normal glands at the first operation and reexploration failed to show whether enlargement of any of the previously normal glands had occurred or an ectopic, enlarged fifth gland was present, since no glands could be found.

It is clear that, in contradiction with the reports in the literature, true recurrence must be very rare. False recurrence due to inadequate exploration occurs more frequently. 


\section{Aparathyroidism}

In three patients all four parathyroid glands were erroneously removed. We consider this to be a severe mutilation of the endocrine system, even though all these patients were cured of hyperparathyroidism. Although aparathyroidism can be compensated for by substitution therapy, it may be difficult to arrive at, and maintain the desired normocalcemia. In a sense the situation is comparable to that of a diabetic who requires treatment with insulin throughout life.

We have already described above (Case 6) the way in which one of our patients became aparathyroidic due to the treatment of a (probably false) recurrence. At this re-exploration the remaining two glands were found in the thymus. The error which was then made was that, in divergence from our principle, the resection of the found (normal) gland was performed before the heterolateral side was explored. At that moment we failed to realize that with the resection of this tumor all the possibly present parathyroid tissue would be removed. If we had realized this, subtotal resection might have offered a solution.

The second patient was re-explored after two normal parathyroids had been removed and a 'blind' subtotal thyroidectomy and a bilateral thymectomy had been performed at two operations done elsewhere. At re-exploration we found a partially retrosternally located tumor which in view of the vascularization must have developed in the left upper parathyroid. This 15-g tumor was totally resected, after which the plasma [Ca] dropped to $6.7 \mathrm{mg} \%$. At present, seven years after the last operation, substitution therapy is still required.

The third patient had undergone a subtotal thyroidectomy 10 years before the parathyroid exploration. At operation a small remnant of the thyroid gland proved to be still present. On the lower right side a parathyroid tumor weighing $600 \mathrm{mg}$ was resected, after which a hypocalcemia of $7.6 \mathrm{mg} / 100 \mathrm{ml}$ developed. At present, seven years after the operation, the patient is still receiving substitution therapy.

We are of the opinion that in all these patients no functioning parathyroid tissue and therefore no circulating PTH are present. For this condition we have introduced the term aparathyroidism.

In the first patient this situation could have been avoided. In the patients treated elsewhere with radical surgery we would have done better to resect the tumor subtotally instead of totally. In two other patients in whom there was an analagous situation, in one case we implanted a small piece of the tumor, with preservation of the vascular pedicle, in the sternocleidomastoid muscle and removed the rest of the tumor, which resulted post-operatively in permanent normocalcemia, and in the other case the tumor was completely resected. In the latter case fortune favored the patient: post-operatively, a persisting normocalcemia developed spontaneously, indicating that unobserved and functioning parathyroid tissue must have been present. 
Because primary hyperplasia is being diagnosed histologically with increasing frequency in both normal-sized and enlarged parathyroid glands, a preventive subtotal parathyroidectomy was performed in 11 patients in our series without regard to the local findings. The macroscopically enlarged and sometimes normal glands were removed in the hope of reducing the number of future recurrences. An estimated 15 to $60 \mathrm{mg}$ (average $30 \mathrm{mg}$ ) parathyroid tissue belonging to one or two glands with the least enlargement or most normal appearance was left in place. In 3 of the 11 patients no hypocalcemia developed after the successful operation. Five of the patients showed a slight hypocalcemia that responded to the administration of supplementary calcium for one week to two months after the operation.

Three patients in whom there could be no question of severe calcium deficiency of the bone or of aparathyroidism (30-35 mg parathyroid tissue belonging to two glands had been left in place), developed a severe hypocalcemia post-operatively, which required correction with calcium and vitamin $\mathrm{D}$ preparations in spite of the risk involved in this treatment. In one of these patients this substitution therapy is still required at present, three years after the operation; for one of the others the duration of substitution is not known to us, and the third required substitution for a period of two years.

We have attempted to determine the degree to which the removal of normal parathyroid glands influences the post-operative calcium pattern. In the presence of severe deficiency in the bone, hypocalcemia of course always develops. We have been unable to demonstrate any correlation between the duration and severity of the hypocalcemia on the one hand and the amount of parathyroid tissue left in place on the other. The extent to which a possible overproduction of calcitonin is of influence here is not known.

Concerning the chances of prevention of a recurrence of hyperparathyroidism by this approach, we are unable to give a conclusive opinion after such a short period. It may be said, however, that in view of the fact that we have seen a (false) recurrence in only $3.1 \%$ of our patients and that this was mainly due to inadequate exploration, we consider that, under the condition that all the glands are inspected, little value is to be attached to the preventive subtotal parathyroidectomy. The high incidence of severe hypoparathyroidism $(37 \%)$ after this treatment seems to us to constitute an even stronger argument for not removing macroscopically entirely normal glands. The possibility of a post-operative hypoparathyroidism must always be 
taken into account. It does not seem premature to assume on the basis of the present results that after a successful parathyroid exploration a prolonged asymptomatic hypocalcemia can develop, but no data on this point are available in the literature. The occurrence of asymptomatic hypoparathyroidism after thyroidectomy is known. In tetany the diagnosis hypocalcemia is not difficult. But the less overt forms of hypocalcemia and sometimes hypomagnesemia due to hypoparathyroidism are harder to distinguish. The symptomatology is highly variable, ranging from anxiety, depression, suicidal tendencies, and exogenic psychoses (Holtz 1932, 1934, Flink 1956, Fourman 1967, Anderson 1968, Newton \& Summich 1968) to ill-defined manifestations of neuromuscular hyperexitability such as intestinal cramps and epileptic insults. Other findings are eczema, cataract, calcification of the basal ganglia, and papiledema due to elevated intracranial pressure (Kyle et al. 1954, Dimich et al. 1967). These symptoms are described in hypoparathyroidism after thyroidectomy, but they are equally likely to occur after deliberate parathyroidectomy. No cases of this kind were found in our material. In a few patients, however, we did see depressions - sometimes several months after the operation - but because the possibility of hypocalcemia was not taken into account, no determination of the plasma [Ca] was made. These pictures must certainly be kept in mind in connection with the post-operative care of our patients. The same actually applies to any patient with the scar of a collar incision on the neck. 


\section{Chapter XII - Summary and conclusions}

In the present work the data concerning 267 patients in whom a parathyroid gland exploration was performed are analysed. The diagnosis primary hyperparathyroidism was confirmed histologically in 255 of these cases.

The number of normal parathyroid glands and their localizations are described on the basis of the data reported in the literature, from which our findings show little divergence. When a thorough exploration is performed, four glands are usually found, the frequency increasing with the accumulation of experience. To obtain good surgical results it is necessary, however, to take into account the fact that in 3 to $6 \%$ of the cases a total of more than four glands, or more than two glands on one side, are present. The localization of the normal glands is indicated: the upper parathyroids are usually situated against the posterior surface of the thyroid gland at the level of the cricoid cartilage, the lower parathyroids usually on the lower poles of the thyroid gland. Enlarged glands lie almost as often in the normal area as the normal glands. Tumors of the upper parathyroid glands in particular seem able to migrate caudally and dorsally over a considerable distance, even as far as the posterior mediastinum. Lastly, the difficulties and limitations involved in locating a parathyroid tumor via the vascular pedicle arising from the inferior thyroid artery are indicated.

The importance and functional activity of the various types of cell found in the parathyroid gland (chief, transitional, water-clear, and oxyphil cells) are not yet known. The composition of the parenchyme varies widely with the age and the activity of the parathyroid gland. The normal picture for a given age must be known before the histological distinction between normal and pathological glands can be made.

A brief discussion of the physiology of the parathyroid hormone and calcitonin is followed by a description of the pathological aspects of the abnormal gland. During the past ten years, solitary adenoma has been diagnosed somewhat less frequently and primary chief cell hyperplasia increasingly often. Multiple adenomata and primary water-clear cell hyper- 
plasia are seldom found at present. However, analysis of the criteria applied for the various pictures shows that the absolute criteria formerly employed for the distinction between these pictures have been used less and less often in recent years. For instance, the rim of normal tissue is found not only in adenomata but also in hyperplastic glands. Furthermore, a normal gland may be found not only in cases of adenoma but also in primary hyperplasia. The differentiation between adenomata and hyperplasia is therefore almost impossible to make and, even worse, the difference between pathological and normal tissue cannot be demonstrated in more than a few cases. For the surgeon, however, the histological investigation in conjunction with the operation is indispensable to avoid confusion between thyroid, parathyroid, thymic, and lymphatic tissue.

The problem of the pathogenesis of primary hyperparathyroidism is dominated by two main points. First, the only known stimulus for the parathyroid gland is hypocalcemia. Second, in hypercalcemia we find hyperplastic glands that histologically appear to lack an autonomous function. A theoretical explanation for this phenomenon is sought. Since tertiary hyperparathyroidism is repeatedly described, an attempt was made to identify a phase of (limited) hypocalcemia due to other than external causes in primary hyperparathyroidism as well. Affections of the thyroid gland appear to be found with surprising frequency as concomittant diseases, but it is not clear to what extent there is a causal relationship between thyroid disease and hyperparathyroidism. Hypercalcitoninism, acromegaly, hyperglucagonemia, and pancreatitis, may give rise to secondary and tertiary hyperparathyroidism. Seen in this light, the autonomous hyperparathyroidism seen in multiple endocrine adenomatosis could possibly be tertiary, although in the latter disease and in hyperparathyroidism, if only on the basis of the familial occurrence of both, the possibility of a genetic error must be taken into account.

The parallel between the more frequent occurrence of primary hyperparathyroidism and osteoporosis in women in the menopause remains unexplained. The relationship between other diseases and primary hyperparathyroidism also seems to be a matter of chance. A developmental scheme for the histopathogenesis of the parathyroid tumors is given.

Early diagnosis and treatment of hyperparathyroidism improves the prognosis. A description is therefore given of the pattern of symptoms and signs, which are composed of a highly variable number of components, in the hope of promoting the consideration of the possibility of hyperparathyroidism in an early stage of the disease. For early diagnosis, however, the routine calcium determination is found to be eminently suitable. 
Some ways to obtain confirmation of the diagnosis are also given. This usually boils down to the exclusion of other causes of hypercalcemia.

Primary hyperparathyroidism is found predominantly in the age-group of 30 to 65 years. It is a striking fact that the disease occurs twice as often in women over the age of 45 as in men of the same age. Before the 45th year there is no predilection for either sex. When determination of the plasma calcium level is done routinely, the number of identified cases of primary hyperparathyroidism increases. It is estimated that 1 to 3 per thousand of the total number of patients admitted to a hospital suffer from primary hyperparathyroidism.

The surgical technique of the parathyroid exploration is designed primarily to obtain an easily surveyed, i.e. a widely opened, bloodless surgical field. Damage to the recurrent laryngeal nerve is avoided by determining the course of this nerve initially. The nerve is also useful for locating the glands. The indications for a one-stage or a separate sternotomy in connection with the removal of expected mediastinal tumors are given. Retrosternal exploration via the cervical incision is advised. In this respect the thymus exploration is of fundamental importance, even when four glands have already been found. The importance of palpation of the thyroid gland and thyroidotomy for the exposure of intra-thyroidal tumors is pointed out. The indications for partial thyroidectomy are given. Total or subtotal thyroidectomy is considered to be a technical error. The secret of success in parathyroid exploration is based on three principles:

1. All (four) glands must be exposed if possible.

2. When a gland is found it must be carefully dissected in its entirety as far as the hilus, so that the size can be evaluated. It may only be considered enlarged on the basis of macroscopic appearance alone and not on the histological picture it shows. For these two points - the exposure and the evaluation - patience and experience are of paramount importance.

3. Only after as many glands or tumors as possible have been dissected free, is a plan made for the resection. The details of this plan depend upon the number of glands found, the guarantee of good vascularization (vitality), and whether all the glands are enlarged or normal glands are also present.

An exploration performed in this way will result in the lowest number of recurrences and the least aparathyroidism.

Lastly, it may be mentioned that it is extremely important to record the findings made during an exploratory operation, for the event that re-exploration proves necessary. 
In 255 of the 267 explored patients, parathyroid tumors were resected. A negative exploration was due to a mistaken diagnosis in only four cases, three concerning sarcoidosis and one 'pseudo-hyperparathyroidism'. Of the 31 re-explorations in patients referred because of unsuccessful explorations, we also failed to find tumors in five cases, mainly due to marked fibrosis in the surgical field. This emphasizes the importance of finding all the glands at the first operation.

The localization of the 939 glands found in our material is given. Of these, $15.8 \%$ had a distinctly abnormal situation. We found partially or completely retrosternally located glands in $36 \%$ of our patients. This percentage exceeds all the values given in the literature, mainly due to the high number of intra-thymically situated glands. This localization can be expected in $22.1 \%$ of the patients. Retrosternal tumors lying outside the thymus occur in $13.8 \%$ of the patients. Tumors with an abnormal localization far dorsally, e.g. behind the trachea and esophagus, were found only ten times. Such tumors almost always originate from the upper parathyroids. Intrathyroidally situated glands are to be expected in $5.5 \%$ of the patients.

The surgical results obtained with the described technique may be called good for the patients who underwent their first exploration in our department. Aside from the negative explorations caused by a wrong diagnosis, normocalcemia was obtained in the first instance in $99 \%$ of the cases, an average of 3.5 glands being found per patient. The results in referred patients were less satisfactory: re-exploration failed in 7 of these 31 cases $(23 \%)$.

Analysis of the origin of the tumors shows that in principle there is no preference in this respect for a given gland. This conclusion is in disagreement with the data in the literature. It emphasizes, however, that all the glands must be located if the surgical treatment is to be successful, since the number and origin of the tumors is highly variable and unpredictable. There is a discrepancy between the number of tumors found by us per patient and the reported percentages of solitary adenomas and multiple adenomata in the literature. This may be explained by the fact that in primary hyperplasia not all the glands are affected per definition.

In fifteen patients intra-thyroidal tumors were found. Normal glands were found in the thyroid gland twice. Regarded retrospectively, thyroidotomy seems to serve adequately for the detection of intra-thyroidal tumors. When a multinodular goiter is present, lobe resection may be required to obtain certainty concerning the presence of a small intra-thyroidal parathyroid gland.

The results obtained with the surgical method described here, in 260 
patients in whom primary hyperparathyroidism was demonstrated clinically and biochemically, were satisfactory. In $92.4 \%$ of the cases there was permanent euparathyroidism after the operation. In $4.2 \%$ a certain degree of hypercalcemia persisted. Three patients $(1.2 \%)$ suffer from aparathyroidism as a result of the operation.

There were few surgical complications. Only one patient now has a permanent unilateral paralysis of a vocal cord. In two cases a major blood vessel was damaged. All these complications were due mainly to fibrosis after prior operation elsewhere. Two patients developed pneumothorax in connection with a sternotomy, but this never occurred after retrosternal exploration through the cervical incision.

One patient died post-operatively as the result of a hypercalcemic crisis, and one other of the consequences of the Zollinger-Ellison syndrome.

To the best of our knowledge, only one of our patients has died of kidney damage caused by the hyperparathyroidism.

Seven $(3.1 \%)$ of the patients first treated surgically by us developed a recurrence of the primary hyperparathyroidism. In the strict sense none of these cases can be called a true recurrence (i.e. enlargement of a previously normal gland); they are rather false recurrences caused by inadequate exploration and failure to excise a tumor. In view of the importance assigned here to this finding for the argumentation against preventive subtotal parathyroidectomy, the case histories of these patients are given.

Thus, true recurrence is certainly rare. In our experience, too, after preventive subtotal parathyroidectomy a severe and prolonged hypocalcemia is seen fairly often. For these reasons we do not advocate this treatment.

As the result of an inadequately planned resection, three patients in this series now suffer from aparathyroidism. Because this endocrine mutilation is serious, the background of the errors made in these explorations are discussed.

Finally, the dangers of the difficult to recognize post-operative hypoparathyroidism are discussed. 


\section{Samenvatting en conclusies}

In dit proefschrift werden de gegevens van 267 patienten, waarbij een bijschildklierexploratie was verricht, geanalyseerd. Bij 255 van hen werd de diagnose primaire hyperparathyreoidie bij pathologisch-anatomisch onderzoek bevestigd.

Aan de hand van gegevens uit de literatuur wordt het aantal normale bijschildklieren en hun ligging beschreven. Onze bevindingen wijken weinig af van die uit de literaturur. Bij een goed uitgevoerde exploratie worden meestal vier klieren gevonden, hetgeen met het toenemen van de ervaring steeds vaker gelukt. Voor een goed operatieresultaat moet men er echter rekening mee houden dat in 3-6\% der gevallen meer dan vier klieren in totaal, of ook wel meer dan 2 klieren aan één zijde aanwezig zijn. De localisatie van de normale klieren wordt aangegeven: de bovenste bijschildklieren bevinden zich meestal tegen het schildklierachtervlak ter hoogte van de cartilago cricoidea, de onderste meestal aan de schildklieronderpolen. Vergrote klieren liggen verhoudingsgewijs vrijwel even vaak op de normale plaats als normale klieren. Vooral tumoren van de bovenste bijschildklieren lijken over een grote afstand naar caudaal en dorsaal zelfs tot in het mediastinum posterius te kunnen migreren. Tenslotte wordt gewezen op de mogelijkheden en beperkingen om een bijschildkliertumor via de vaatsteel, uitgaande van de arteria thyreoidea inferior te kunnen localiseren.

Het is niet gelukt de betekenis en de functionele activiteit van de verschillende celtypen (hoofdcel, transitionele cel, waterheldere cel en oxyphiele cel) te achterhalen. De opboww van het parenchym wisselt sterk met de leeftijd en de activiteit van de bijschildklier. De kennis omtrent het voor een bepaalde leeftijd normale beeld is noodzakelijk om de histologische grens tussen normale en pathologische klieren te kunnen maken.

$\mathrm{Na}$ een korte bespreking van de fysiologie van het parathyreoid hormoon en het calcitonine wordt de pathologische anatomie beschreven. De laatste tien jaren blijkt het enkelvoudig adenoom iets minder vaak gevonden te worden. Steeds vaker wordt een vorm van de primaire hoofdcellen hyper- 
plasie gediagnostiseerd. Multipele adenomata en primaire waterheldere cellen hyperplasie wordt weinig meer gevonden. Bij de bestudering van de maatstaven, welke voor de verschillende beelden zijn gehanteerd blijkt echter dat de vroegere absolute criteria voor het onderscheid van deze beelden de laatste jaren steeds minder worden aangehouden: Het randje normaal weefsel wordt niet alleen bij adenomen, doch ook bij hyperplastische klieren gevonden. Verder kan een normale klier niet alleen bij adenomata, doch ook bij primaire hyperplasie worden gevonden. De differentiatie tussen adenomen en vooral de nodulaire hyperplasie is dan ook vrijwel onmogelijk en sterker nog: het verschil tussen pathologisch en normaal weefsel is nogal eens niet aan te geven. Voor de chirurg is het histologisch onderzoek bij de operatie echter onmisbaar om verwarring tussen bijschildklier-, schildklier-, thymus- en lymfeklierweefsel te voorkomen.

Het probleem van de pathogenese van de primaire hyperparathyreoidie wordt beheerst door twee kernpunten: De enige ons bekende bijschildklierstimulus is hypocalciaemie. Bij hypercalciaemie worden hyperplatische klieren, welke histologisch dus geen autonome functie lijken te hebben gevonden. Voor dit fenomeen wordt een theoretische verklaring gezocht. Aangezien de tertiare hyperparathyreoidie herhaaldelijk is beschreven, wordt getracht ook bij de primaire hyperparathyreoidie een fase van (geringe) hypocalciaemie door niet externe oorzaken, op te sporen. Schildklieraandoeningen blijken opvallend vaak als concommitterende ziekten te worden gevonden. Het is niet duidelijk in hoeverre hypothyreoidie en hyperparathyreoidie oorzakelijk verband met elkaar houden. Hypercalcitoninisme, acromegalie, hyperglucagonaemie en pancreatitis geven mogelijk aanleiding tot secundaire en tertiaire hyperparathyreoidie. In dit licht bezien is de autonome hyperparathyreoidie zoals die gevonden wordt bij multipele endocriene adenomatose mogelijk tertiair, hoewel bij deze laatste ziekte en bij hyperparathyreoidie alléén gezien het familiaire voorkomen van beiden een genetische fout een rol kan spelen. De parallel van het frequenter voorkomen van primaire hyperparathyreoidie en osteoporose bij vrouwen in de menopauze blijft onverklaarbaar. Ook de relatie tussen andere ziekten en primaire hyperparathyreoidie lijkt een toevallige. Tenslotte wordt een ontwikkelingsschema voor de histopathogenese van de bijschildkliertumoren gegeven.

Een vroege diagnose en therapie van de hyperparathyreoidie begunstigt de prognose. Daarom wordt het klachtenpatroon en de symptomatologie welke samengesteld zijn uit een zeer variabel aantal compomenten beschreven. Dit in de hoop de gedachte aan hyperparathyreoidie in een vroeg stadium te doen opkomen. De routine calciumbepaling lijkt daarvoor echter het meest geschikt. Tevens worden enkele richtlijnen ter verificatie van de 
diagnose aangegeven. Meestal komt dit neer op het uitsluiten van andere oorzaken van hypercalciaemie.

Primaire hyperparathyreoidie wordt vooral in de leeftijdsgroep van 30-65 jaar gevonden. Opvallend is, zoals reeds gezegd het feit, dat de ziekte tweemaal vaker bij vrowwen boven het $45 \mathrm{e}$ jaar wordt gevonden dan bij mannen van dezelfde leeftijd. Voor het $45 \mathrm{e}$ jaar is de verdeling over beide geslachten gelijk. Bij invoering van het plasma calcium als routinebepaling stijgt het aantal gevonden lijders aan primaire hyperparathyreoidie per jaar. Naar schatting lijden 1-3\% van het totale aantal patienten welke een ziekenhuis bezoeken aan primaire hyperparathyreoidie.

De operatietechniek van de bijschildklierexploratie is primair gericht op een goed overzichtelijk, dus ruim opengelegd operatieterrein, waarin bloedverlies uit den boze is. Beschadiging van de nervus laryngeus recurrens wordt voorkomen door het verloop van deze zenuw voor alles te vervolgen. De zenuw is tevens van waarde voor het localiseren van de klieren. De indicaties tot eenstaps sternotomie en sternotomie in een afzonderlijke operatie voor te verwachten mediastinale tumoren wordt aangegeven. Retrosternale exploratie vanuit de cervicale incisie wordt geadviseerd. Daarbij is de thymus exploratie van essentieel belang, ook al werden reeds vier klieren gevonden. Er wordt gewezen op het belang van de schildklierpalpatie en de thyreoidotomie ter ontsluiting van intrathyreoidale tumoren. De indicaties voor partiële thyreoidectomie worden aangegeven. Totale thyreoidectomie wordt als een kunstfout beschouwd. Het geheim van het succes van de bijschildklierexploratie is gegrondvest op drie principes:

a) Alle (vier) klieren moeten zo mogelijk a vue worden gebracht.

b) Gevonden klieren moeten voorzichtig in hun geheel tot aan de hilus worden vrijgeprepareerd om hun omvang te kunnen overzien. Daarna wordt pas beslist of de klieren vergroot zijn of niet. Hierbij wordt alleen afgegaan op het macroscopische aspect en niet op de histologische opbouw van de klier. Voor deze twee punten is geduld en ervaring een eerste vereiste.

c) Pas nadat zoveel mogelijk klieren c.q. tumoren zijn vrijgeprepareerd wordt een resectieplan opgemaakt. De uitwerking hiervan berust op het gevonden aantal klieren, de waarborg voor een goede vascularisatie (vitaliteit) en of zij alle vergroot zijn, of dat er normale klieren aanwezig zijn. Een op deze wijze uitgevoerde exploratie resulteert in het kleinste aantal recidieven en de minste aparathyreoidiën. 
Tenslotte wordt gewezen op het grote belang de bevindingen bij exploratie nauwkeurig aan te geven in verband met een eventuele reëxploratie.

Bij 255 van de 267 geëxploreerde patienten werden bijschildkliergezwellen gereseceerd. Slechts viermaal werd een negatieve exploratie veroorzaakt door een fout in de diagnose: driemaal sarcoidosis en eenmaal door 'pseudohyperparathyreoidie'. Van de 31 reëxploraties bij patienten waar reeds elders de operatie was mislukt kon ook door ons vijfmaal geen succes worden geboekt vooral door sterke fibrose van het operatieterrein. Dit benadrukt de noodzaak om reeds bij de eerste operatie een volledig succes te boeken.

De localisatie van de 939 gevonden klieren wordt aangegeven. Hiervan waren er $15,8 \%$ op een duidelijk abnormale plaats gelegen. Door ons werd bij $36 \%$ der patienten gedeeltelijk of geheel retrosternaal gelegen klieren gevonden. Dit percentage overtreft alle andere in de literatuur gegeven getallen. Dit wordt voornamelijk veroorzaakt door de grote hoeveelheid intrathymisch gevonden klieren. Deze localisatie valt bij $22,1 \%$ der patienten te verwachten. Retrosternale klieren buiten de thymus komen bij $13,8 \%$ van de patienten voor. Abnormaal ver naar dorsaal gelegen klieren zoals achter de trachea en oesophagus troffen wij slechts tienmaal aan. Deze gaan praktisch altijd uit van de bovenste bijschilklieren. Intrathyreoidale klieren moet men bij 5,5\% der patienten verwachten.

De technische operatieresultaten van de beschreven techniek waren bij de patienten, welke hun eerste exploratie bij ons ondergingen zonder meer goed. Afgezien van de negatieve exploraties, veroorzaakt door een fout in de diagnose werd in $99 \%$ der gevallen in eerste instantie een normocalciaemie

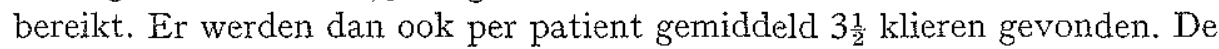
resultaten bij de patienten, welke ons na een mislukking elders waren toegestuurd waren minder gunstig: Bij 7 van hen $(23 \%)$ mislukte de reëxploratie.

Bij analyse van de oorsprong der tumoren blijkt, dat er in principe geen voorkeur is voor een ontaarding van één bepaalde klier. Dit in tegenstelling tot de gegevens uit de literatuur. Tevens wordt nogmaals duidelijk, dat alle klieren opgezocht moeten worden om succes te boeken: Het aantal tumoren en hun aflkomst is zeer wisselend en onvoorspelbaar.

Er blijkt een discrepantie te bestaan tussen het door ons gevonden aantal tumoren per patient en de opgaven van het percentage enkelvoudige adenomata en multipele adenomata in de literatuur. Mogelijk is de verklaring hiervan, dat bij de primaire hyperplasie niet per definitie alle klieren zijn aangedaan.

Voor het localiseren en de resectie van de tumoren was sternotomie slechts 
bij 3 patienten noodzakelijk. Deze tumoren lagen alle meer dan $5 \mathrm{~cm}$ onder de sternumrand. Gezien het grote aantal retrosternale klieren en het geringe aantal sternotomiën blijkt het grote belang van de retrosternale exploratie vanuit de halsincisie overduidelijk. Vijfmaal werd een sternotomie op foutieve grond verricht.

Bij 15 patienten werden intrathyreoidale tumoren gevonden. Tweemaal troffen wij normale klieren in de schildklier aan. Retrospectief gezien lijkt de thyreoidotomie afdoende voor het opsporen van de intrathyreoidale tumoren. Kwabsresectie kan, vooral wanneer er een multinodulair struma bestaat, noodzakelijk zijn on zekerheid te verkrijgen omtrent de aanwezigheid van een kleine intrathyreoidale bijschildklier.

Het resultaat van de operatie bij 260 patienten waarbij primaire hyperparathyreoidie op klinische en biochemische gronden vaststaat is wanneer de reeds beschreven techniek wordt gevolgd gunstig. In $92,4 \%$ der gevallen ontstond na operatie een blijvende euparathyreoidie. Bij 4,2\% der patienten bleef een zekere mate van hypercalciaemie bestaan. Drie patienten $(1,2 \%)$ werden door de operatie aparathyreoot.

Er waren weinig operatieve complicaties. Slechts één patient heeft een eenzijdige blijvende paralyse van de nervus laryngeus recurrens. Tweemaal werd een belangrijk vat beschadigd. Deze complicaties zijn vooral het gevolg van fibrose in het operatieterrein. Tweemaal ontstond een pneumothorax in aansluiting op een sternotomie, doch nimmer na retrosternale exploratie via de halsincisie.

Eén patient overleed postoperatief door een hypercalciaemische crisis, een andere patient aan de gevolgen van het Zollinger-Ellison syndroom.

Tot dusver bekend overleed slechts één van onze patienten aan de door de hyperparathyreoidie veroorzaakte nierbeschadiging.

Bij $7(3,1 \%)$ van de in eerste instantie door ons geopereerde patienten werd een recidief van de primaire hyperparathyreoidie gevonden. In strikte zin is bij géén van hen sprake van een werkelijk recidief (dat wil zeggen door uitgroei van een tevoren normale klier) doch van een vals recidief (wat wordt veroorzaakt door het achterblijven van een tumor bij een insufficiënte exploratie). Gezien het belang van deze bevinding voor de te ontraden zogenaamde preventieve subtotale parathyreoidectomie worden de ziektegeschiedenissen van deze patienten bediscussieerd. Het werkelijke recidief is dus zeldzaam. Verder treedt volgens onze ervaring na de preventieve subtotale parathyreoidectomie nogal eens een ernstige en langdurige hypocalciaemie op. Om deze redenen zijn wij geen voorstanders van deze techniek. 
Door een ondoordacht resectieplan lijden thans nog drie patienten aan aparathyreoidie. Gezien de ernst van deze endocriene mutilatie worden de achtergronden van de fouten van deze exploraties weergegeven.

Tenslotte wordt gewezen op de gevaren van de moeilijk te herkennen postoperatieve hypoparathyreoidie. 


\section{Literature}

ADAms, H. D. and R. MurPHY (1963): The management of primary hyperparathyroidism, Surg. Gyn. \& Obst.: 116: 45-52.

Adams, P. H., et al. (1965): Primary chiefcell hyperplasia of the parathyroid glands. Ann. Int. Med.: 63: 454-67.

Albo, D. JR and L. E. Stevens (1968): A rationale for thorough surgical exploration in primary hyperparathyroidism, Amer. J. Surg.: 116: 674-677.

AlBRIGHT, F. et al. (1969), (a): Studies of calcium and phosphorus metabolism IV: the effect of the parathyroid hormone, J. Clin. Invest.: 7: 139-181.

Albright, F. and R. ElLsworth (1929), (b): Studies on the physiology of the parathyroid glands 1: calcium and phosphorus studies on a case of idiopathic hypoparathyroidism. J. Clin. Invest.: $7: 183-201$.

ALFREY, A. C. et al. (1968): Resolution of hyperparathyroidism, renal osteodystrophy and metastatic calcification after renal homotransplantation, New Engl. J. Med.: 279: 1349-56.

ANDERSON, J. (1968): Psychiatric aspects of primary hyperparathyroidism, Proc. Roy. Soc. Med.: 61: 43-44.

ANDERSON, L. and LINDHOLM T. (1967): Less common manifestations of hyperparathyroidism, Acta Med. Scand.: 182: 411-18.

ARNAUD, C. D. et al. (1970): Calcium homeostasis, parathyroid hormone and calcitonin: preliminary report, Mayo Clin. Proc.: 45: 125-131.

ArNaUd, C. D. et al. (1971): Radioimmuno assay of human parathyroid hormone in serum, J. Clin. Invest. 50:21-34.

Askanazy, M. (1904): Ueber osteitis deformans ohne osteoides Gewebe, Arb. path. Anat. Bact. zu Tübingen: 4: 398-422.

Askanazy, M. (1906): Verh. dtsch. ges. path. 10:85

Atrie, J. N. et al. (1967): Parathyroid adenomas discovered incidentally during explorations of the thyroid, Am. J. Surg. : 174: 538-542.

AzZaLr, Calcitonin 1969 (Symposion London).

Balashev, V. N. and Ignasmina N. S. (1964): Lymphatic system of parathyroidglands in man, Problemy Endocr. i Gormonoter: 10: 603-604.

BARNICOT, N. A. (1948): The local action of the parathyroid and other tissues on bone in intracerebral grafts, J. anat.: 82: 233-250.

BARTelheimer, H. und KuHLencoRdt F. (1967): Primärer, sekundärer und testiärer Hyperparathyreoidismus, Medizinische Klinik: $62: 821-825$.

BartletT, N. L.; Cochran, D. Q. (1964): Reparative processes in primary hyperparathyroidism, Radiol. Clin. N. Amer.: 2: 261-79. 
Bauer, W. C. et al. (1930): A case of osteitis fibrosa cystica (osteomalacia?) with evidence of hyperactivity of the parathyroid bodies. Metabolic study II, J. Clin. Invest. : $8: 229-247$.

BAUERMEISTER, D. E. et al. (1967): Hypercalcaemia with seizures - a clinical paradox, JAMA: : 201: 132-4.

BAY V. et al. (1967): Eine Beitrag zur tertiären Hyperparathyreoidismus, Langenbecks Archiv für Klin. Chir.: 319: 202-206.

Beahrs, O. H. and VANDERToll, D. J. (1963): Complications of secondary thyroidectomy, Surg. Gyn. Obst.: 117: 535-539.

Bernstern, Calcitonin 1969 (Symposion) Heinemann, London 1969.

Berson, S. A. et al. (1963): Immunoassay of bovine and human parathyroid hormone, Proc. Nat. Acad. Sci.: 49:613-617.

Berson, S. A. and YALOW R. S. (1966): Parathyroid hormone in plasma in adenomatous hyperparathyroidism, uremia and bronchogenic carcinoma, Science: 154: 907-909.

BERSon, S. A. and Yalow R. S. (1967): Radioimmunoassays of peptide hormones in plasma, The New England J. Med.: 277: 640-8.

Berge, S. J. and Avioli L. V. (1969): Glucagon-induced hypocalcaemia in man, J. Clin. Endocrin. : 29:213-218.

BirKenHÄGER J. C. and BIRKENHÄGER-FrEnkel D. H. (1968): On the clinical significance of the chemical composition of bone, Folia Med. Neerl.: 11: 155-161.

BLACk, B. M. (1952): Surgical treatment of hyperparathyroidism, Surg. Clin. of North Am.: 32: 1031-1042.

BLACK, B. M. (1963): Difficulties in the treatment of hyperparathyroidism, Surg. Clin. N. Am: 43; 1115-21.

BLACK, W. C. and UTLEY J. R. (1968): The differential diagnosis of parathyroid adenoma and chief cell hyperplasia, Amer. J. Clin. path.: 49: 761-775.

Block, M. A. et al. (1967): Involvement of multiple parathyroids in hyperparathyroidism, Am. J. Surg.: 114: 530-537.

Bote, S. T., Lxynse and GERbRandy J. (1962): Influence of serum calcium concentration on QT-interval and circulation, Clin. Chem., Acta: 7; 432-436.

Boonstra $\mathrm{CH}$. E. and JACKSON CH. E. (1965): Hyperparathyroidism detected by routine serum calcium analysis, Am. Int. Med.: 63: 468-74.

BORDIER: calcitonin 1969 (Symposion) Heinemann, London 1969.

BORLE, A. B. (1963): Role of parathyroid hormone in phosphate transport across rat duodenum, Am. J. Physiol. 204: 705-709.

Bortz, W. et at. (1961): Differentiation between thyroid and parathyroid causes of hypercalcemia, Ann. Int. Med.: 54: 610-619.

Bowser, E. N. et al. (1968): Glucagon-induced hypocalcaemia in the rat, J. Lab. Clin. Med. : $72: 857$.

Boyd, J. D. (1950): Development of the thyroid and parathyroid glands and the thymus, Am. Roy Coll. Surg. Engl.: $7:$ 455-471.

Boyce, T. MCH (1962): Hyperparathyroidism and the rhinologist, J. Laryngol, and Otol. : $76: 247-265$.

BRADSHAw, H. H. et al. (1964): Long-term results in patients with parathyroid surgery, Ann. Surg. 160: 1017-20.

Bradshaw H. H. (1966): An attempt to tell the clinical story of the parathyroid glands, especially in their hyperfunctioning states, Medical Times 94: 95-100. 
Buge, A. and Mrgnot B. (1964): Les myopathies endocriniennes, Rec. Pract. 14 : 547-55.

Bussolati G. and Pearse, A. G. E. (1967): Immuno-fiuorescent localisation of calcitonin in the ' $C$ ' cells of pig and dog thyroid, J. Endocrin. 37: 205-209.

Bijvoet, O. L. M. and VAN DeR Sluys Veer J. (1968): The homeostasis of plasma calcium and phosphate, Folia Med. Neerl.: 11:161-178.

Bijvoet, O. L. M. et al. (1968): Effects of calcitonin on patients with Paget's disease, thyreotoxicosis, or hypercalcaemia, Lancet I: 876-881.

BiJvote, O. L. M. et al. (1970): Effecten van calcitonine op de calcium en natriumhuishouding van patiënten, Ned. Tijdschr. v. Geneesk. 114: 988.

CAREY, M. C. and FitzGerald, O. (1968): Hyperparathyroidism associated with chronic pancreatitis in a family, Gut: 9:700-703.

Castleman, B. and Mallory, T. B. (1935): The pathology of the parathyroid glands in hyperparathyroidism, Am. J. Path. 11: 1-72.

Castleman, B.: Washington D. C. 1952, Atlas of tumor pathology; Section IV, fasc. 15.

Castleman, B., KrbBeE B. U. (1963): Case records of the Massachusetts General Hospital, New Engl. J. Med.: 268: 943-53.

ChamerRs, E. L. et al. (1956): Tests for hyperparathyroidism: tubular reabsorption of phosphate, phosphate deprivation and calcium infusion, J. Clin. Endocr.: 16: 1507-1521.

CHIU-AN WANG, et al (1970): Localisation of hyperfunctioning parathyroids. The surgeons' riddle, Am. J. Sur.: 119: 462-464.

Chodack, P. et al. (1965); Hypercalcaemic crisis coincidental with hemorrhage in parathyroid adenoma, Arch. Int. Med,: 116;416-423.

Christie A. C. (1967), The parathyroid oxyphil cells, J. Clin. Pathol. 20: 591-602.

Churchile, E. D. and COPE, O. (1934): Parathyroid tumors associated with hyperparathyroidism, Surg. Gyn. Obst.: 55: 255-271.

Coffey, R. J., Potter J. F. and J. J. CANary (1965): Diagnosis and surgical control of hyperparathyroidism, Am. Surg. 161: 732-6.

Cogan, D. G., Albrighr, F. and Bartter F. C. (1948): Hypercalcaemia and band keratopathy. Arch. Opthalmol. 40: 624-638.

Cogan, D. G. and P. H. Henneman (1957): Diffuse calcification of the cornea in hypercalcaemia, New. Engl. J. Med. 257: 451-543.

Colim, J. B. (1925), (a): The extract of a parathyroid hormone which will prevent or control parathyroid tetany and with regulates the level of blood calcium, J. Biol. Chem. : 63: 395-438.

Collip, J. B. et al. (1925), (b): The effect of a parathyroid hormone on normal animals, J. Biol. Chem. 63: 439-460.

Collip, J. B. et al. (1934): Observations concerning the mechanism of parathyroid hormone action, Brit. J. Exp. Pathol.: 15: 335-336.

Cope, O. et al. (1958): Primary chief-cell hyperplasia of the parathyroid giands. Ann. Surg. : 148: 375-389.

Cope, O. (1960): Hyperparathyroidism: diagnosis and treatment, Amer. J. Surg.: 99: 394-403.

Copre, O. et al. (1961): Vicisstitudes of parathyroid surgery. Trials of diagnosis and management in 51 patients with a variety of disorders, Ann. Surg.: 154:491-508.

COPE, O. (1966): The story of hyperparathyroidism at the Massachusetts General Hospital, New. Engl. J. Med.: 274: 1174-82. 
Copp, D. H. et al. (1962): Evidence for calcitonin - A new hormone from the parathyroid that lowers blood calcium, Endocrinology: 70:638-49.

CopP, D. H. et al. (1967): Ultimobranchial origin of calcitonin. Hypocalcaemic effects from chicken glands. Canad. J. Physiol.: 45: 1095-9.

Copp, D. H.: Parathyroid hormone, calcitonin and calcium homeostasis, Eds. Exerpta Medica Found, Int. Congress Series 159, Amsterdam 1968, p. 25 39.

Cosgrove, K. E. and LA Tourette $\mathrm{K}$. A. (1953): Multiple myeloma simulating hyperparathyroidism, Amer. J. Med.: 15: 862-874.

CUNLIFFe, W. J. (1968): A calcitonin-secreting thyroid carcinoma. The Lancet I: 63-66.

Cutler, R. E., Reiss, E. and Ackerman, L. V. (1964): Familiar hyperparathyroidism A kindred involving eleven cases, with a discussion of primary chief cell hyperplasia, New. Engl. J. Med.: 270: 859-865.

Davies, D. R., Dent C. E., Wrllcox, A. (1956): Hyperparathyroidism and steatorrhoea, Brit. Med. J.: 2: 1133-37.

Davies, D. R. (1966): Parathyroid disease, Ann. Roy Coll. Surg. Eng.: 39: 145-50.

Davies, D. R., Dent, C. E. and Watson, L. (1968): Tertiary hyperparathyroidism, Brit. Med. J.: 3: 395-399.

Davis, M. E., Strandjord, N. M. and LanzL, L. H. (1966): Estrogens and the aging process, J.A.M.A.: 196: 219-224.

Dent, C. E. (1962), (a): Some problems of hyperparathyroidism, Brit. J. Med.: 217: 1419-25.

DENT, C. E. (1962), (b): Some problems of hyperparathyroidism, Brit. Med. J.: 217 : 1495-1500.

Dent, C. E. and Watson, L. (1966): Hyperparathyroidism and sarcoidosis, Brit. Med. J. I: 646-649.

Dent, C. E. and Warson, L. (1968): The hydrocortison test in primary and tertiary hyperparathyroidism, Lancet II: 662-664.

Drmich, A. et al. (1967): Hypoparathyroidism, Arch. Int. Med, : 120: 449-458.

Dossel, W. E. (1958): An experimental study of the locus of origin of the chick parathyroid, Anat. Rec.: 132: 555-562.

DutTA, P. and Wallace, M. R. (1968): Familial multiple endocrine adenopathy (Primary hyperparathyroidism and Zollinger-Ellison Syndrome) in two siblings, Proc. Roy Soc. Med. : 61: 16-18.

EDER, M. (1961), (a): Morphologischen Untersuchungen über herdförmigen Epithelkörperchen hyperplasien, Virchows Arch. Path. Anat.: 334: 301-323.

EDER, M. (1961), (b): Experimentelle und histochemische Untersuchungen über herdförmige hyperplasien im Epithelkörperchen, Virchows Arch. Path. Anat.: 334: 324-336.

EGDAHX, R. H. et. al. (1968): Measurement of circulating parathyroid hormone concentration before and after parathyroid surgery for adenoma or hyperplasia, Ann. of Surgery: 168:714-71s.

EISENBERG, E. (1.968): Effects of varying phosphate intake in primary hyperparathyroidism, J. Clin. Endocr.: 28: 651-660.

EISIENBERG, E. and GorH, F. A. (1968): Normocalcaemic hyperparathyroidism culminating in hypercalcaemic crisis, Arch. Int. Med.: 22: 258-264. 
Eliel, L. P., Thomson C. and Chanes, R. (1965): Antagonism between parathyroid extract and adrenal cortical steroids in man, J. Clin. Endocr.: 25: 457-464.

ElLis, C. and NrcholofF, D. M. (1968): Hyperparathyroidism and peptic ulcer disease. Arch. Surg.: 96: 114-118.

Ellison, E. H. et al. (1964): The Zollinger-Ellison Syndrome, Ann. Surg.: 160: 512-530.

ENGFELDT, B. et al. (1959): Elektron mikroskopi och histokemi vid parathyroideaadenom, Nordisk Med. 9: 558-559.

ERDheim, J. (1904): Uber Schilddrüsenaplasie II, Gewiulste des Ductus thyreoglossus III Uber einige menschliche Kiemenderivate, Beitr. Path. Anat. 35: 366-433.

ERdhem, J. (1906): Tetania parathyreopriva, Mitteilungen aus dem Grensgebiet d. Med. und Chir. 16: 632-744.

Ertel, N. H., Reiss, J. S. and Spergel, G. (1969): Hypomagnesiaemia in neonatal tetany associated with maternal hyperparathyroidism, New. Eng. J. Med.: 280 : 260-262.

Fanconi, A. und Mieth, D. (1967): Primäre hyperparathyreoidismus bei einem 12jährigen Knaben, Helv. Paed. Acta: 22: 160-169.

FEIND, C. R. (1964): Re-exploration for parathyroid adenoma, Amer. J. Surg. 108: 543-6.

FInBY, N. and BEGG, C. F. (1969): Correlation conferences in radiology and pathology: Dilemma of hyperparathyroidisn, New York State J. Med. (1969): 296-301.

Fischer J. A. et al. (1968): Normocalciämischer Hyperparathyroidismus bei der Malabsorption, Schweiz Med. Wochenschr.: 98: 721-722.

FISHER, J. A. et al. (1969/1970): Normocalcaemic secondary hyperparathyroidism and Malabsorption, Helv. Med. Acta: 35: 30-42.

FlrNk, E. B. (1956): Magnesium deficiency syndrome in man, J.A.M.A. 160: 14061410.

Fogr-Andersen, P. (1954): Adenomata of the parathyroid glands, Acta Chir. Scand. 107: 321-4.

FosteR, G. V. et al. (1964): Thyroid origin of calcitonin, Nature 202; 1303-1305.

Foster, G. V. (1966): Thyrocalcitonin: failure to demonstrate a parathyroid releasing factor, Nature 5055: 1319-20.

Foster, G. V. et al. (1966): Effect of thyrocalcitonin on bone, The Lancet II: 14281431.

Foster, G. V. et al. (1966): Effect of thyrocalcitonin in man, The Lancet I: 107-109.

Foster, G. V. (1968): Calcitonin (thyrocalcitonin), New. Engl. J. Med. 279: 349-360.

Fourman, P. (1967): Parathyroid function after thyroidectomy, W. James Irvine: Thyrotoxicosis (E \& S Livingstone LTD), p. 192-210.

Fourman, P. et al. (1967): Calcium Metabolism and the bone, 2nd Ed. Oxford: Blackwell Scientific publications, pp. 656.

Fourman, P. et al. (1969): Parathyroid insufficiency after thyroidectomy, Brit. J. Surg. : 50: 608 619 .

Frame, B. et al. (1968): Myopathy in primary hyperparathyroidism. Observations in three patients, Ann. Int. Med.: 68: 1022-1027.

FRIDERICHSEN, C. and Rosendal, TH. (1968): A 30 year follow up of a case of cured hyperparathyroidism, Acta Endocrinology: 59: 371-378. 
Gaillard, P. J. (1968): The effect of parathyroid hormone on desmal and long bone rudiments 'in vitro', Folia Med. Neerl.: 11: 186-189.

Galante, L. et al. (1968): Thymic and parathyroid origin of calcitonin in man, Lancet II: $537-539$.

Gardner, R. J. and Koppel, D. M. (1969): Hyperparathyroid crisis, Arch. Surg. 98: 674-676.

Gilmour, J. R. and Makmin, W. J. (1937): The weight of the parathyroid glands, J. Path. and Bact.: $44: 431-462$.

GILmour, J. R. (1938): The gross anatomy of the parathyroid glands, J. Path. and Bact. : 46:133-149.

Gilmovr, J. R. (1939): The normal histology of the parathyroid glands, J. Path. and Bact. 48: 187-222.

GItTES. R. F. and IRviN, G. L. (1965): Thyroid and parathyroid roles in hypercalcaemia; evidence for a thyrocalcitonin-releasing factor, Science 148: 1737-9.

GrtTES, R. F. and RADDE, I. C. (1966): Experimental hyperparathyroidism from multiple isologous parathyroid transplants: homeostatic effect of simultaneous thyroid transplants, Endocrinology: 78: 1015-22.

GitTes, R. F. and WeLLS, S. A. (1967): Thyrocalcitonin treatment of experimental hyperparathyroidism in rats, J. Surg. Research: 7:1-7.

Golden, A., Canary, J. J. and Kerwin, D. M.: Concurrence of hyperplasia and neoplasia of the parathyroid glands.

GolDSMITH, R. S. and INGBAR, S. H. (1966): Inorganic phosphate treatment of hypercalcaemia of diverse etiologies, New. Engl. J. Med.: 274:1-7.

Goldsmith, R. S., Zalme, E. and Weinstein, A. S. (1966): Clinical experience with primary hyperparathyroidism: evaluation of treatment, Acta Endocr. 52: 221-238.

Goldsmith, R. S. (1969): Hyperparathyroidism, New Engl. J. Med. 281: 367-374.

Goodman, Mi. L. et al. (1969): Hyperparathyroidism from intrathyroid parathyroid adenomas, Arch. Path. 87: 418-422.

Graber, A. L. and Jacobs, K. (1968): Familial hyperparathyroidism, J.A.M.A.: 204: 542-544.

Graham, W. P. and Royster, H. P.: (1967): Parathyroid disease: changing concepts Penn. Med. 60.

Gray, S. J. (1964): Endocrinopathies and peptic ulcer, Am. J. Dig. Dis.: 9: 279-84.

GrenNWALD, I. and Gross J. (1926): The effect of long-continued administration of parathyroid extract upon the excretion of phosphorus and calcium $\mathrm{J}$. Biol. Chem. 68: 325-333.

Gudmundsson, T. V. et al. (1969): Plasma calcitonin in man. The Lancet I: 443-6.

Gudmundsson, T. V. et al.: CaIcitonin 1969, (Symposion) Heinemann, London 1969.

GuY, CH. C.: Tumors of the parathyroid glands, Surg. Gyn. \& Obstr.: 48: 557-565 pre-1929.

HaAs, H. G., Dubach, U. C. and Affolter, H. (1964): Wirkung des Zweites Nebenschilddrüsen-hormons Calcitonin beim Menschen, Helv. Med. Acta.: 37: 442-50.

HALSTED, W. S. (1907): Hypoparathyreosis, status parathyreoprivus and transplantation of the parathyroid glands, Am. J. Med. Sciences: 134:1-12.

Halsted, W. S. and Evans, H. M. (1907): The parathyroid glandules, Their blood supply and their preservation in operation upon the thyroid gland, Ann. Surg.: 46: $489-506$. 
Hamlton, W. J., Boyd, J. D. and Mossman, H. W. (1962): Human Embryology, W. Hefferand sons LTD, Cambridge.

Hannon, R. R. et al. (1930): A case of osteitis fibrosa cystica (osteomalacia?) with evidence of hyperactivity of the parathyroid bodies, Metabolic Study I, J. Clin. Invest. : 8 : 215-228.

Harris, J. C. et al. (1966): Primary hyperparathyroidism with parathyroid hyperplasia and adenoma in a single gland, Am. J. Clin. Path. : 45: 51-55.

Hartog, M. et al. (1967): Acromegaly and hyperparathyroidism, Proc. Roy Soc. IVed.: $60: 477$.

Heimann, P. et al. (1970), (a): Parathyroid and thyroid disease I: parathyroid disease discovered during surgical exploration of the thyroid, Acta. Chir. Scand.: 136: 139-141.

HeImann, P. et al. (1970), (b): Parathyroid and thyroid disease II: thyroid disease connected with hyperparathyroidism, Acta chirg. Scand.: 135: 143 146.

HeINBACH, W. F. (1933): A study of the number and location of the parathyroid glands in man, Anat. Rec.: $57: 251-257$.

Hekmelman, J. W. (1968): Mode of action of parathormon on bone tissue, Folia Med. Neerl.: 11: 190-194.

HellNeR, H. (1965): Hyperparathyroidismus, Der Chirurg: 36: 103-9.

Hellström, J. (1953): Further observations regarding the prognosis and diagnosis in hyperparathyroidism, Acta Chir. Scand.: 105: 122-31.

Hellström, J. and Ivemark, B. I. (1962): Primary hyperparathyroidism. Clinica1 and structural findings in 138 cases, Acta Chir. Scand. suppl.: 294, pp. 113.

HelistRöm, J. (1965): The treatmenè of hyperparathyroidism, Urol. Int.: 19: 124-30.

Higgins, G. A. (1964): Surgical aspects, Med. Ann. of Columbia 33: 549-56.

HrRsch, P. F. et al. (1963): Thyroid hypocalcaemic principle and recurrent laryngeal nerve injury as factors effecting the response to parathyreoidectomy in rats, Endocrinology: 73: 244-251.

HodGkinson, A. (1963): Biochemical aspects of primary hyperparathyroidism: an analysis of 50 cases, Clin. Sci.: 25: 231-242.

Hodgkinson, A. \& EdWards, N. A. (1963); Total and ultra filterable serum calcium in primary hyperthyroidism, Brit. J. Urol. : 35: 445-56.

Holmes, E. C.; Morton, D. L. and Ketcham, A. S. (1969): Parathyroid carcinoma: a collective review, Ann. Surg.: 169: 631-640.

Holtz, F. (1932): Die Behandlung der postoperativen Tetanie, Arch. für Klin. Chir.: 1777: $32-34$.

Holtz, F. (1934): A. T. 10. Deutsche Med. Wochenschr.: 48: 1830-1831.

Holzman, K. and Lange, R. (1963): Zur Zytologie der Glandula Parathyreoidea der Menschen, Zeitschr. für Zellforsch.: 58: 759-789.

Horeau, J. et al. (1965): Le syndrome pseudo hyperparathyroidien des tumeurs sans metastases osseuses, Presse Medicale: 53: 3057-60.

HotTa, T. (1965): Histochemical studies on the parathyroid gland of the rat during pregnancy and puerperium, Okajimas Fol. Anat. Jap.: 41: 49-71.

Houston, J. B. et al. (1968): Radiography of secondary hyperparathyroidism, Oral Surgery: $26: 746-750$.

Howard, J. E. and Thomas, W. C. (1963): Clinical disorders of calcium homeostasis, Medicin: 42:25-45. 
Howell, J. S. (1965): Difficulties in the diagnosis of parathyroid tissue from frozen sections, Brit. J. Surg.: 52: 514-516.

HubNeR, P. J. B. (1967): Acromegaly and hyperparathyroidism, Brit. Med. J. II : 812.

Hunt, P. S. (1968): A reappraisal of the surgical anatomy of the thyroid and parathyroid glands, Brit. J. Surg.: 55:63-66.

JEREMY, D. (1968): Hyperparathyroidism after renal transplantation, Brit. J. Urol.: 40: 491.

Jowsey, J. and RaIsz, L. G. (1968): Experimental osteoporosis and parathyroid activity, Endocrinology: 82: 384-395.

Jowsey, J. and Srmons, G. W. (1968): Normocalcaemia in relation to cortisone secretion, Nature: $217: 1274-1279$.

Karpatr, G. and Frame, B. (1964): Neuropsychiatric disorders in primary hyperparathyroidism, Arch. Neurol.: 10: 387-397.

KAtz, R. et al. (1964): Symposium on hyperparathyroidism, Med. Ann. of Columbia: 33: $543-5$.

Keating, F. R. (1962): Diagnosis of primary hyperparathyroidism: Clinical and laboratory aspects, J.A.M.A.: 178: 547-555.

Keating, F. R. et al. (1969), (a): Distribution of serum calcium and phosphorus values in unselected ambulatory patients, J. Lab. and. Clin. Med.: 74: 507-514.

KeAting, F. R. et al. (1969), (b): The relation of age and sex to distribution of values in healthy adults of serum calcium, in organic phosphorus, magnesium, alkaline phosphatase, total proteins, albumin and bloodurea, J. Lab. \& Clin. Med.: 73: 825-834.

KELLY, TH. R. (1968): Relationship of hyperparathyroidism to pancreatitis, Arch. Surg.: 97: 267-274.

KELLY, TH. R. and FALOR, W. H. (1968): Hyperparathyroid crisis associated with pancreatitis, Ann. Surg.: 168:917-920.

KeLLy, TH. R. (1969): Parathyroid carcinoma, a case report and review of literature, The Am. Surg.: 35: 374-376.

KLEEMAN, CH. R. et al. (1958): The effect of parathyroid extract on the renal clearance of diffusible calcium, Am. Soc. Clin. Invest.: 37: 907.

Kracht, J. and HachmeIster, U.: Calcitonin (1969) (symposion) Heineman, London 1969.

Kramer, W. M. (1970): Association of parathyroid hyperplasia with neoplasia, Am. J. Path.: 53: 275-283.

Kоноuт, E. (1966): Serum calcium levels and parathyroid glands in malignant disorders, Cancer: 19: 925-934.

KuHLenCORDT, F. and KRACHT, J. (1968): Chronischer Hyperparathyreoidismus mit C-Zellenhyperplasie der Schilddrüse, Deutsche Medizinische Wochenschrift 50; 2411-15.

KYLE, L. H. et al. (1954): Unrecognized postoperative hypoparathyroidism, J. Clin. Endocr.: 14: 579-587.

KYLE, L. H. et al. (1958): Phosphate clearance in the diagnosis of parathyroid dysfunction, Am. J. Med.: 28: 240-248.

LAFFerty, F. W. and PeARson, O. H. (1963): Skeletal, intestinal and renal calcium dynamics' in hyperparathyroidism, J. Clin. Endocr.: 23: 891-902. 
Lafferty, F. W. (1966): Pseudo-hyperparathyroidism, Medicine: 45: 247-266.

LAING, V. O. et al. (1969): Associated primary hyperparathyroidism and thyroid lesions, Arch. Surg.: 98: 709-712.

Lameyer, L. D. F., De GraefF, J., Struyvenberg, A. and Vink, M. (1967): Autonomy of parathyroid function in a patient with a renal homograft, Folia Med. Neer1.: 10: 45-8.

THE LANCET 1965 vol. I: 361-3. Diagnosis of hyperparathyroidism: Leading article.

LEVIN, M. L. and BELL N. H. (1958): The effects of porcine thyrocalcitonin on phosphorus clearance in the dog, Clin. Res. 76:388.

LEQUIN, R. M.: Radioimmuno-assays for parathyroid hormone and calcitonin, Offset drukk. Faculteit der Wiskunde en Natuurwetenschappen, Nijnegen 1969.

Lzoyd, H. M. (1968): Primary hyperparathyroidism: an analysis of the role of the parathyroid tumor, Medicin: 47: 53-71.

MacCallum, W. G. and Voegtlin, C. (1909): J. Exp. Med. 11: 118-152.

MACLeOD, W. A. J. and Holloway, C. K. (1967): Hyperparathyroid crisis, Am. Surg. 166: $1012-15$.

MANDL, F. (1925): Therapeutischer Versuch bei einem Falle von Osteitis fibrosa generalisata mittels Extirpation eines Epithellörperchen-tumors, Zentral blatt. für Chir.: $5: 260-264$.

Mandu, F. (1926): Klinisches und Experimentelles zur Frage der localisierten und generalisierten Osteitis fibrosa, Archiv. f. klin. Chir.: 143: 245-284.

MANNIX, H. und LoEHR W. J. (1968): Unusual aspects of hyperparathyroidism Surg. Gynec. Obst. : 126: 347-351.

Marks, CH. (1968): Hyperparathyroidism and its clinical effect, Amer. J. Surg.: 116 : $40-48$.

Maurer, W. J., Johnson, J. R. and Mendenhall, J. T. (1965): Mediastinal parathyroid adenoma, J. Thoracic and cardiovas. Surg.: 49:657-662.

Mauro, C. (1950): Contributo allo studio della vascularisatione delle paratiroidi, Giorn, Ital. Chir.: 6: 384-400.

McGEown, M. G.: The biochemical investigation of patients suspected of hyperparathyroidism. XIXe congres de la Soc. Intern. de Chirurgie 1961.

McGeown, M. G. (1963): The causes of kidney stones, Ir. J. Med. Sci: 301-20.

McGeown, M. G. (1965): The results of parathyroidectomy, Urol. Int. 19: 137-43.

McIntosh, D. A., Peterson, E. W. and McPaul, J. J. (1966): Autonomy of parathyroid functions after renal homotransplantation, Ann. Int. Med.: 65: 900907.

Mclellan, G., Baird, C. W. and Melick, R. (1968): Hypercalcaemia in an Australian hospital adult population, Med. J. Aust.: $4: 354-356$.

McPaur, J. J. et al. (1964): Autonomous secondary (renal) parathyroid hyperplasia disease, New. Engl. Med.: 271: 1342-45.

Melvin, K. E. W., Joplin, G. F., ANd Fraser, R. (1968): Normocalcaemic hyperparathyroidism, Proc. Roy Soc. Med.: 61: 87-88.

Melvin, K. E. W. and TAshjian, A. H. JR. (1968): The syndrome of excessive thyrocalcitonin produced bij medullary carcinoma of the thyroid, Proc. N.A.S. 59: 1216-1222.

MieneR, W. C. et al. (1961): Primary hyperparathyroidism, Arch. Int. Med.: 107: 105-115. 
MrLHAUD, et al: Studies on the mode of action and the therapeutic use of thyrocalcitonin, Calcitonin 1967 (Heinemann, London 1967).

MILIZNER, R. J. (1927): J.A.M.A.: 88: 1053-1055.

Múhlethaler, J. P., Schärer, K. and Antener, I. (1967): Akuter hyperparathyreoidismus bei primärer Nebenschilddrüsenhyperplasie, Helv. Paed. Acta: 22: 529-557.

MULIER, H. and SMEENK, D. (1962): Enkele aspecten van primaire hyperparathyroi die: N.T.v.G.: $106: 2314-9$.

Muller, H., Smenk, D. and VAN Der Heul, R. O. (1966): Vijftien jaar ervaring met de chirurgische behandeling van hyperparathyreoidie, N.T.v.G.: 110: 1772-74.

Muller, H. (1969): Sex, age, and hyperparathyroidism, The Lancet I: 449-50.

Myers, R. T. and BHatri, B. (1970): Peptic ulcer and parathyroid adenoma, Ann. Surg. 171: 647-655.

Nathanrels, E. K. et al. (1970): Mediastinal parathyroid tumors: A clinical and pathological study of 84 cases, Am. Surg.: 171: 165-170.

Newton, N. C. and Sumich, M. G. (1.968): Chvostec's sign, hypomagnesemia and behavioural disturbance following parathyroid adenomectomy, Med. J. Australia: 394-8.

Nichols, G. JR. and Flanagan, B. (1967): Normocalcaemic hyperparathyroidism Trans. Ass. Am. Phys. : 314-322.

Nichols, G. (1970): Bone resorption and calcium homeostasis: one process or two? Calc. Tiss. Res.: 4: (suppl.) 61-63.

NonIdez, J. F. (1932): Further observations on the parafollicular cells of the mammalian thyroid, Anat. Rec.: 53: 339-353.

Nonidez, J. F. (1935): The 'parachymatous' cells of Barter, 'the protoplasmareichen Zellen' of Huertle and the 'parafollicular' cells of the mammalian thyroid, Anat. Rec.: $56: 131-141$.

Nordin, B. E. C. et al. (1966): The incidence of osteoporosis in normal women: its relation to age and the menopause, Quart. J. Med. : 35:25-38.

NorRIS, E. H. (1947): The parathyroid adenoma (collective review of 322 cases), Internat. Abstr. of Surg.: $84: 1-41$.

PAK, Calcitonin 1969 (Symposion), Heinemann, London 1969.

Paloyan, E. (1967), (a): Recent developments in early diagnosis of hyperparathyroidism, Surg. Clin. N. Amer.: 47: 61-69.

PAloyan, E. et al. (1967), (b): The role of glucagon hypersecretion in the relations of pancreatitis and hyperparathyroidism, Surgery: 62: 167-73.

PALOYAN, E. et al. (1969): Near-total parathyroidectomy, Surg. Clin. North Am.: 79 : $43-48$.

Pearse, A. G. E. (1966): The cytochemistry of the thyroid C-cells and their relationship to calcitonin, Proc. Roy Soc. B.: 164: 478-487.

Pearse, A. G. E. and Carvalheira, A. F. (1967): Cytochemical evidence for an ultimobranchial origin of rodent thyroid C-cells, Nature 214:929-930.

Pedersen, K. O. (1967): Coexistent sarcoidisis and hyperparathyroidism, Acta Med. Scand.: 182: 781-786.

Petersen, P. (1968): Psychiatric disorders in primary hyperparathyroidism, J. Clin. Endocr.: 28: 1491-5. 
Potrs, J. T. JR. (1968): Parathyroid hormone and thyrocalcitonin: Exerpta Medica foundations, Amsterdam I.C.S. 159: 403-413.

Pyrah, L. N., Hodgkinson, A. and Anderson, C. K. (1966): Primary hyperparathyroidism, Brit. J. Surg.: 53: 245-316.

PYRTEK, L. J. and PAINTER, R. L. (1964): An anatomic study of the relationship of the parathyroid glands to the recurrent laryngeal nerve, Surg. Gyn. and Obstr.: 179: 509-512.

RAIsz, L. G. (1963): Regulation by calcium of parathyroid growth and secretion in vitro, Nature: 197: 1115-1116.

RASMUSSEN, H. (1953): The influence of parathyroid function upon the transport of calcium in isolated sacs of rat small intestine, Endocrinology: 65: 517-519.

RAyBUCK, H. E. (1952): The innervation of the parathyroid glands, Anat. Rec.: 112: $117-123$.

Raymond, NATALIE, (1932): The occurcence of parafolliculair cells in the thyroid of the rabbit, Anat. Rec.: 53: 355-365.

Recklinghausen, F. D. von, (1891): Die fibrose oder deformirende Osteitis, die Osteomalacie und die Osteoplastische Carcinose in ihren gegenseitigen Beziehungen, Festchr. Rudolph Virchow zu seinem 71 Geburtstag gewidmet, Berliner Reiner: 1-89.

Recklinghausen, F. D. von (1910): Untersuchungen über Rachitis und Osteomalacie, Jena.

Renwick, S. B. et al. (1968): Pluriglandular syndrome with hyperparathyroidism and Zollinger-Ellison syndrome, Proc. Roy Soc. Med.: 61: 87 .

RiENHOFF, W. F. et al. (1968): The surgical treatment of hyperparathyroidism, Ann. Surg.: 168: 1061-1074.

Robinson, B. H. B. and WALSER, M. (1964): Plasmacalcium concentration in relation to adrenal function, Bone and Tooth, ed. H. J. J. Blackwood, Pergamon Press, p. $185-191$.

Robinson, C. J., Martin, T. J. and McIntyre, I. (1966): Phosphaturic effect of thyrocalcitonin, Lancet II : 83-84.

Rorr, S. I. (1962): Pathology of the parathyroids in hyperparathyroidism, Arch. Path.: $73: 495-510$.

Roth, S. I. and RaIsz, L. G. (1966): The course and reversibility of the calcium effect on the ultrastructure of the rat parathyroid gland on organ culture, Lab. Invest.: 15: 1187-1211.

RotH, S. I. et al. (1968): Effect of dietary deficiency in vitamin D, calcium and phosphorus on the ultrastructure of the rat parathyroid, Am. J. Path. : 53:631-650.

Rubens, R. D. et al. (1969): Dissimilar adenomas in four parathyroids presenting as primary hyperparathyroidism, Lancet II : 596-598.

RuBIN, A., et al. (1968): Maternal hyperparathyroidism and pregnancy, J.A.M.A.: 206: $128-130$.

Sarosi, G. and DoE, R. P. (1968): Familial occurrence of parathyroid adenomas phaeochromocytoma and medullary carcinoma of the thyroid with amyloid stroma (Sipple's syndrome), Ann. Int. Med.: 68: 1305-9.

Schachner, S. H. et al. (1966): Familial hyperparathyroidism, Arch. Intern. Med. 117: 417-421. 
Schlagenhaufer, F. (1916): (Demonstrations), Münch. Med. W. schr.; 63: 56.

Scrmidr, M. C. et al. (1966): The effects of induced hypercalcaemia on the activity of the parathyroids, Am. J. Path.: 48: 439-449.

Schiriti, J. E. and Hamilton, H. L. (1952): An experimental study of the origin of the parathyroid and thymus glands in the chick, J. Exp. Zool.: 179: 165-187.

SeFteL, L. A. and GusberG, S. B. (1965): Hyperparathyroid states in gynecological malignancy, Obst. \& Gyn.: 25:693-8.

SHERWOOD, L. M. (1967): Relative importance of parathyroid hormone and thyrocalcitonin in calcium homeostasis, New. Engl. J. Med, : 278: 663-670.

Sherwood, L. M. et al. (1967): Production of parathyroid hormone by non-parathyroid tumors, J. Clin. Endocr.: 27: 140-146.

SrPplE, J. H. (1961): The association of phaeochromocytoma with carcinoma of the thyroid gland, Am. J. Med.: 31: 163-166.

VAN DER SLUYS VEER, J. et al. (1964): Tetracyclin labelling of bone in hyperparathyroidism, Transactions of the first European bone and tooth symposion: 85-91.

SmeenK, D. and Muller, H. (1961) : Enkele aspecten van primaire hyperparathyreoidie, N.T.v.G.: 105: 173644.

SMeEnk, D. and VAN Den BRAND, I.B.A.M. (1965): De invloed van de lichaamshouding op hematocriet en het gehalte aan eiwit, calcium, cholesterol en PBI van het bloed, Ned. Tijdschr. v. Geneesk.: 109: 1798-1800.

SMEENK, D. (1968): Some aspects of hyperparathyroidism, Folia Med. Neerl.: 11: 194-201.

Smith, R. and STERN, G. (1967): Myopathy, osteomalacia and hyperparathyroidism, Brain: 90: 593-602.

Solcia: Calcitonin 1969, (Symposion), Heinemann, London 1969.

SoNoDA, $T$. et al. (1967): Screening of primary hyperparathyroidism among the patients with urolithiasis, Urol. Int. : $22: 517-531$.

Sorensen, J. A.: Calcitonin 1969 (Symposion), Heinemann, London 1969.

STATE, D. (1964): The enlarged inferior thyroid artery, a valuable guide in surgery of Parathyroid adenomas, Surgery: $56: 461-462$.

Steyn, J. H., Duncan, T. and Logte, N. J. (1966): The association of pancreatitis with hyperparathyroidism, Brit. J. Surg.: 53: 778-80.

ST. GOAR, W. T. (1957): Gastro-intestinal symptoms as a clue to the diagnosis of primary hyperparathyroidism. A review of 45 cases, Ann. Int. Med.: 46: 102-118.

StRaUs, F. H. and PALOYAN, E. (1969): The pathology of hyperparathyroidism, Surg. Clin. North Am.: 49: 27-42.

Summers, V. K. et al. (1966): Hyperparathyroidism in acromegaly, The Lancet II: 60-63.

Svane, S. (1964): Hypercalcaemia in malignant disease without evidence of bone destruction, Acta Med. Scand.: 175: 353-7.

SWYER, A. J. et al. (1950): Hypercalcaemia in osteolytic metastatic cancer of the breast, Am. J. Med. : 724-732.

Talmage, R. V. and Kraintz, F. W. (1954): Progressive changes in renal phosphate and calcium excretion in rats following parathyroidectomy or parathyroid administration, Proc. Soc, Exp. Biol. and Med.: 87: 263-267.

Talmage, R. V. and Elliot, J. R. (1958): Influence of parathyroids on intestinal absorption of radiocalcium and radiostrontium, Fed. Proc.: 17: 160. 
TALMAGe, R. V. (1967): Aspects of parathyroid physiology in mammals, Am.Zoologist: 7: 825-833.

Tashjian, A. H. and Voelkel, E. F. (1968): Decreased thyrocalcitonin in thyroid glands from patients with hyperparathyroidism, J. Clin. Endocr. : 27: 1353-1357.

TAUber, S. D. (1967): The ultimobranchial origin of thyrocalcitonin, Proc. Nat. Acad. Science: $58: 1684-1687$.

Thompson, I. M. (1964): Hyperparathyroidism, Proc. Roy Soc. Med.: 57: 801-3.

Thomson, D. L. and Pugslex, L. I. (1932): On the mechanism of parathyroid hormone action, Am. J. Physiol. : 102: 350-354.

Transbøl, I., Hahnemann, S. and Hornum, I. (1968): The tubular reabsorption of calcium in primary hyperparathyroidism and in non-parathyroid hypercalcaemia, Acta Med. Scand.: 184: 33-43.

TOVERUD, S. U. et al. (1966): Thyroid and parathyroid glands in recovery from hypercalcaemia, Fed. Proc.: 25: 347.

Trudeau, W. L. and McGuigan, J. E. (1969): Effects of calcium on serum gastrin levels in the Zollinger-Ellison syndrome, New Engl. J. Med.: 281: 862-866.

Utley, J. R. and Black, W. C. (1967): Hyperparathyroidism. Am. J. Surg. 174: 788-795.

VAIL, A. D. (1967): The parathyroid glands: Clinopathologic correlation of parathyroid disease as found in 200 unselected autopsies, Missouri Medicine: 64: 234238.

VANCIL, M. and LockE, W. (1965): Acromegaly, hyperparathyroidism and probable mammary fibroadenoma in a man, Am. J. Surg.: 110:495-7.

Vassale, G. and Generali, F. (1896): Sugli effeti dele' estirpazione delle chiandole parathyroidei, Revista di Patologia Nervosa e Mentale: 1: 95-99.

WADE, J. S. H. et al. (1965), (a): Recovery of parathyroid function in patients with 'transient' hypoparathyroidism after thyroidectomy, Brit. J. Surg.: 52: 493-496.

WADE, J. S. H. et al. (1965), (b): The course of partial parathyroid insufficiency after thyroidectomy, Brit. J. Surg.: 52: 497-503.

WajchenBach, B. L. et al. (1965): Antagonism between adrenal steroids and parathyroid hormone, J. Clin. Endocr.: 25: 1677-81.

WARSHAW, A. L. et al. (1968): Pancreatic insufficiency as the presenting feature of hyperparathyroidism, Ann. Int. Med.: 68: 161-7.

Watanabe, M., Baxter, S. and Beck, J. C. (1961): Recurrence of parathyroid adenoma, Am. J. Med.: 31: 498-503.

WederLin, O. (1964): The parathyroids in primary hyperparathyroidism, A histological study of 35 cases, Acta Path. et Microbiol. Scand.: 61: 211-32.

WERmER, P. (1954): Genetic aspects of adenomatosis of endocrine glands, Am. J. Med. : $16: 367-371$.

WERMER, P. (1963): Endocrine adenomatosis and peptic ulcer in a large kindred, Am. J. Med. : 35: 205-212.

Weymouth, R. J. and Sheridan, M. N. (1966): Fine structure of human parathyroid glands: normal and pathological, Acta Endocrinol. : $53:$ 529-546.

Williams, E. D. et al. (1966): Pathological and clinical findings in a series of 67 cases of medullary carcinoma of the thyroid, J. Clin. Path.: 19:103-113. 
Wrllrams, G. A. et al. (1969): Mode of hypocalcaemic action of glucagon in the rat, Endocrinology: 85: 537-541.

Wills, M. R. et al. (1969): Normocalcaemic primary hyperparathyroidism, Am. J. Med.: 47: 384-391.

Wilson, R. E. et al. (1964): Hyperparathyroidism: the problem of acute parathyroid intoxication, Ann. Surg.: 759: 79-93.

WILSON, R. E. et al. (1965): Effects of parathyroidectomy and kidney transplantation in renal osteodystrophy, Amer. J. Surg.: 170: 384-93.

WinNacker, J. L. et al. (1969): Sarcoidosis and hyperparathyroidism, Am. J. Med.: 46: 305-312.

Woolner, L. B. et al. (1952): Tumors and hyperplasia of the parathyroid glands, Cancer: 5: 1069-1088.

YENDT, E. R. and GAGNÊ, R. J. A. (1968): Detection of primary hyperparathyroidism, with special reference to its occurrence in hypercalciuric females with normal or borderline serum calcium, Canad. Med. Ass.: 98: 331-336.

Yonis, Z. et al. (1962): Primary hypoparathyroidism in an infant, Am. J. Dis. Child.: 104: 131-134.

Young, (1969), Calcitonin 1969 (Symposion), Heinemann, London 1969.

ZawisTowskr, ST. (1965): Histochemical studies on the adrenergic innervation of the parathyroid gland of albino rat, Zeitschr. für Mikroskopisch-Anatomische Forschung: $39-45$. 


\section{Acknowledgements}

The author wishes to acknowledge his indebtedness to Professor H. Muller, who was responsible for the successful surgical treatment of most of the patients in this series, for putting his case reports at his disposal for analysis. His clear and logical formulation contributed greatly to the value of this material.

The author is also grateful to Professor J. C. Birkenhäger, endocrinologist for invaluable discussions and his critical reading of the manuscript.

Dr. R. O. van der Heul, pathologist, who investigated the histological material from the beginning of the series, is certainly one of the first to have recognized the existence of primary chief cell hyperplasia.

The high rate of surgical success in this series would certainly not have been achieved without the diagnostic contribution of Professor D. Smeenk, Dr. J. van der Sluys Veer, and Professor J. C. Birkenhäger.

The author also wishes to thank Professor M. Vink for permission to part of his series for the present analysis.

The grants from the Dutch Ministry of Education and Sciences are gratefully acknowledged. The translation was done by Mrs. I. Seeger.

Thanks are extended to Miss L. van der Hoek, Miss E. Drooglever, Miss. T. Peek, Miss G. Storm, and Miss Y. Barendrecht, who typed the manuscript. The figures were prepared by Mrs. J. Leusink of the Audiovisual Department of the Rotterdam Faculty of Medicine.

Lastly, the author wishes to thank his colleagues F. Lahr, Th. van Vroonhoven, K. Bijlsma, A. Vos, B. D. Verhoog, and M. M. P. Haalebos for taking over his function while this work was in preparation. 


\section{Curriculum vitae}

H. A. Bruining werd geboren te Eindhoven in 1943, alwaar hij het lager en middelbaar onderwijs ontving.

Het diploma HBS-b werd in 1962 behaald.

Hierna studeerde hij Geneeskunde te Leiden en legde daar het artsexamen af in 1968.

$\mathrm{Na}$ het vervullen van de militaire dienst trad hij in 1970 als arts-assistent in dienst van de afdeling Heelkunde van het Academisch Ziekenhuis Dijkzigt te Rotterdam. 